

Universidade de Brasília

Instituto de Ciências Biológicas

Programa de Pós-Graduação em Ecologia

\title{
O Novo Código Florestal e a Reserva Legal do Cerrado
}

\author{
Gustavo Bediaga de Oliveira
}

Orientador: Prof ${ }^{o}$ John Du Vall Hay

Coorientador: Prof ${ }^{0}$ Ricardo Bomfim Machado

Dissertação apresentada ao Programa de Pós-Graduação em Ecologia da Universidade de Brasília como parte dos requisitos necessários para a obtenção do título de Mestre em Ecologia.

Brasília - DF 


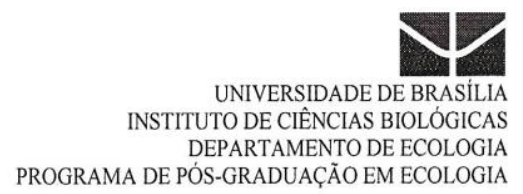

Dissertação de Mestrado

\section{GUSTAVO BEDIAGA DE OLIVEIRA}

Título:

\section{"O novo Código Florestal e a Reserva Legal do Cerrado"}

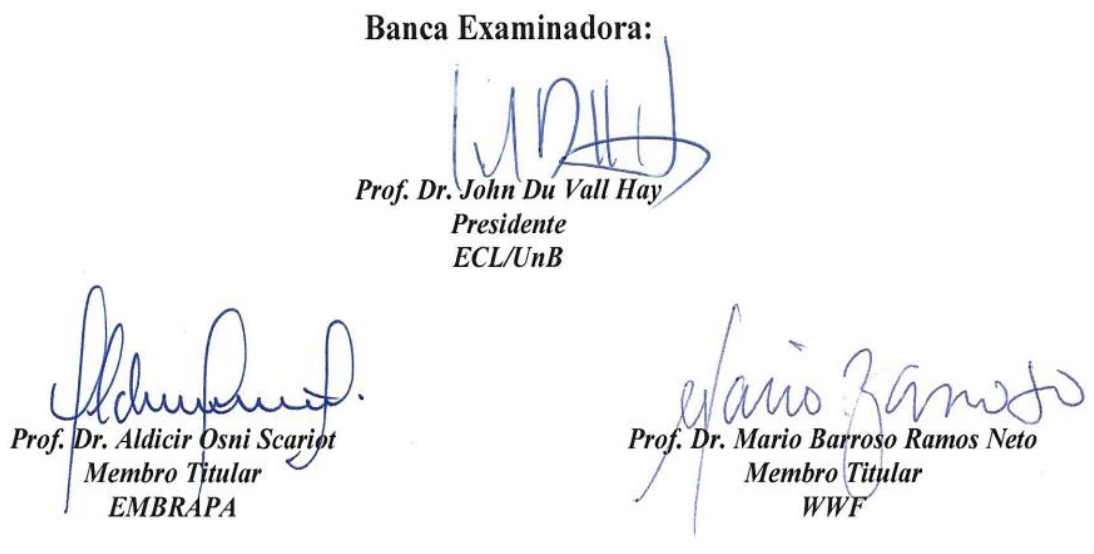

Prof.. Dr. ${ }^{a}$. Mercedes Maria da Cunha Bustamante

Suplente

$E C L / U n B$

Brasília, 11 de fevereiro de 2015. 


\section{AGRADECIMENTOS}

Aos meus pais, Ricardo e Begonha, por terem me dado apoio durante toda a minha vida para que eu alcançasse meus objetivos. Sem vocês nada disso seria possível.

Ao Professor John Hay, por ter me aceitado como orientando e me auxiliado durante todo o mestrado. Também agradeço o Professor Ricardo Machado, que enriqueceu este trabalho com valiosas contribuições.

Agradeço a todos os professores da Ecologia/UnB, por terem transmitido seus conhecimentos durante o curso, muitos me recebendo fora de sala de aula, o que contribuiu muito para a execução desta pesquisa.

Agradeço à Prof. Marinez Siqueira, por ter me recebido tão bem em seu laboratório e ter auxiliado na elaboração desta dissertação. Também agradeço à Prof. Mercedes Bustamante pelos ensinamentos passados em aula e por ser um exemplo na difícil arte da docência.

Expresso aqui minha gratidão ao Instituto Brasileiro do Meio Ambiente e dos Recursos Naturais Renováveis por confiar na minha capacitação e conceder a licença que possibilitou a execução deste trabalho.

À todos que me auxiliaram durante o período desta pesquisa, especialmente à Renata Françoso, Ricardo Haidar, Vívian Ribeiro, Danilo Oliveira e Peter Wimmer, que, através de conversas informais com certeza delinearam de alguma forma os rumos desta pesquisa.

Por fim agradeço à Lílian, em sua companhia tudo fica mais fácil. Obrigado pela paciência de me ouvir falar durante horas sobre os temas desta pesquisa, e pelas diversas sugestões que melhoraram o trabalho. 
"Quando cada brasileiro souber o que representa uma floresta, como fator de sua própria sobrevivência e de seu bem estar, poderemos então abolir as penalidades, por absolutamente desnecessárias."

Min. Armando Monteiro Filho, no relatório do Código Florestal em 1962. 


\section{ÍNDICE}





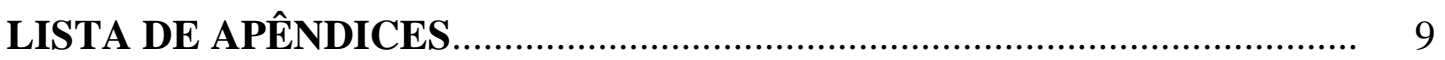

RESUMO



CAPÍTULO 1

A RESERVA LEGAL NO CÓDIGO FLORESTAL DE 1934 a 2012 ............. 15

Histórico da Reserva Legal no Brasil............................................................... 15

As Medidas Provisórias de 1996 a 2001.............................................................. 18

O Novo Código Florestal de 2012 .................................................................. 21

As mudanças do Novo Código Florestal na Reserva Legal.................................... 23

A anistia do Novo Código Florestal na Reserva Legal.......................................... 24

As formas de regularização da RL em propriedades acima de quatro módulos fiscais

A reação da comunidade científica às mudanças no Código Florestal, com enfoque na Reserva Legal.......................................................................... 31

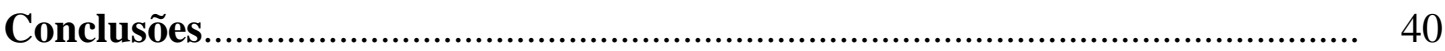

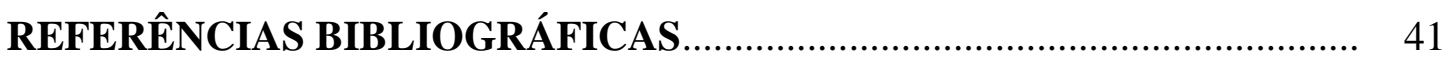

CAPÍTULO 2

EFEITOS DA ANISTIA DO NOVO CÓDIGO FLORESTAL NAS RESERVAS LEGAIS DO CERRADO ....................................................... 45





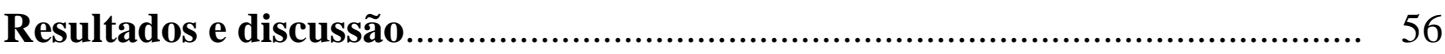

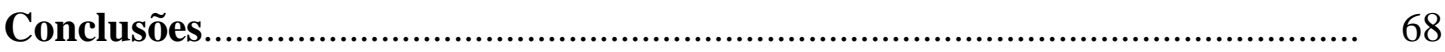

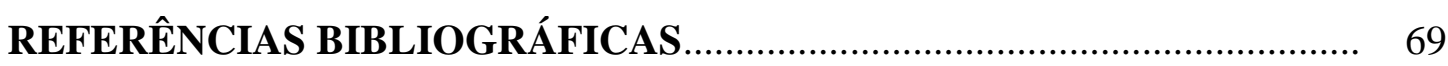

CAPÍtULLO 3

MUDANÇAS NA COMPENSAÇÃO DE RESERVA LEGAL NO CERRADO: RESOLVENDO UM PROBLEMA PARA CRIAR OUTRO? ... 73

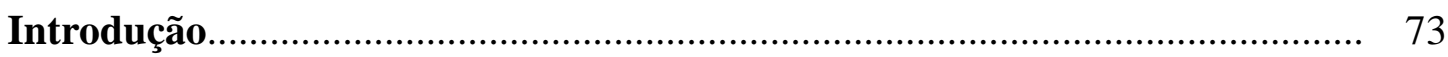

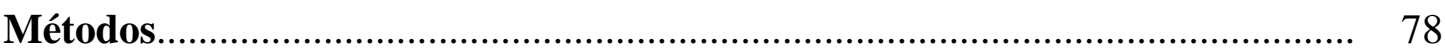

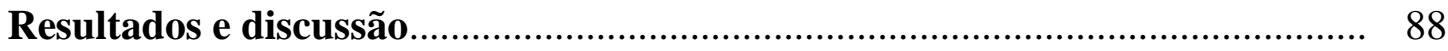


Conclusões.

99

REFERÊNCIAS BIBLIOGRÁFICAS......................................................... 100

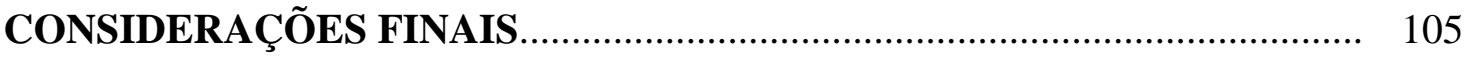

REFERÊNCIAS BIBLIOGRÁFICAS ..................................................... 107

APÊNDICES 


\section{LISTA DE FIGURAS}

\section{Capítulo 1}

Figura 1 - Algumas das Medidas Provisórias editadas e suas principais alterações na Reserva Legal ao longo do tempo.

\section{Capítulo 2}

Figura 1 - Cenas do satélite LANDSAT utilizadas no Projeto de Monitoramento dos Biomas Brasileiros por Satélite, acordo com a data da anistia 56

Figura 2 - Distribuição das propriedades com Reserva Legal preservada e com algum desmate no bioma Cerrado.

\section{Capítulo 3}

Figura 1 - Microbacias do nível Otto5 (em diferentes cores) contidas em uma única microbacia do nível Otto3

Figura 2 - Cenários gerados para compensação de Reserva Legal.

Figura 3 - Grupos de Microbacias Intercambiáveis que deverão ser recuperados em cada cenário.

Figura 4 - Posição de cada cenário nas métricas analisadas. 


\section{LISTA DE TABELAS}

\section{Capítulo 1}

Tabela 1 - Regularização de áreas de Reserva Legal desmatadas até 22/07/2008... 28

Tabela 2 - Mudanças nas regras de compensação de Reserva Legal........................ 31

\section{Capítulo 2}

Tabela 1 - Matriz de decisão para possibilidade de anistia nas áreas de Reserva

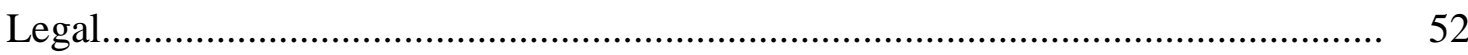

Tabela 2 - Análise das áreas desmatadas de Reserva Legal no Cerrado................. 60

Tabela 3 - Número de imóveis com áreas de Reserva Legal (RL) preservadas em relação ao Marco Temporal de 22/07/2008 ........................................................... 61

Tabela 4 - Número de imóveis com Reserva Legais em diferentes condições por Unidade de Federação, em relação ao Marco Temporal de 22/07/2008................... 64

Tabela 5 - Principal atividade agropecuária seguida da lavoura temporária com maior área plantada nos municípios e a média da porcentagem de propriedades que

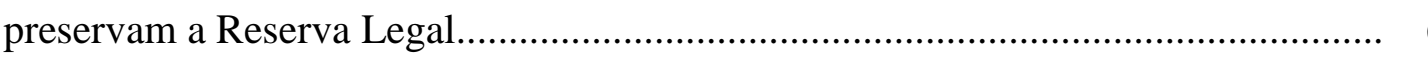

\section{Capítulo 3}

Tabela 1 - Mudanças nas regras para compensação de Reserva Legal.................... 74

Tabela 2 - Variáveis ambientais utilizadas na Modelagem de Nicho Climático....... 82

Tabela 3 - Número de Grupos de Microbacias Intercambiáveis e área média de cada cenário.

Tabela 4 - A porcentagem média e máxima de perda de espécies na compensação de Reservas Legais em cada cenário analisado.

Tabela 5 - Métricas de cada cenário apresentado. 


\section{LISTA DE APÊNDICES}

\section{Capítulo 3}

Apêndice 1 - Lista das 119 espécies utilizadas na modelagem............................ 108

Apêndice 2 - Modelos finais já cortados pelo threshold, com o valor de TSS,

AUC e valor de $\mathrm{p}$ do teste binomial................................................................... 112 


\section{RESUMO}

Em 2012 o Código Florestal brasileiro foi alterado, mudando muitas das regras que disciplinam a conservação dos ecossistemas nativos. O objetivo desta dissertação foi analisar alguns dos impactos das mudanças da nova lei na conservação da Reserva Legal (RL) no bioma Cerrado. Para tanto, esta dissertação foi dividida em três capítulos.

No Capítulo 1, demonstraram-se as diversas alterações sofridas pela RL desde sua concepção, em 1934, passando pela sua primeira revisão, em 1965, até sua última alteração, em 2012. Dentre as principais, ressalta-se a mudança de um tamanho fixo de RL em todo o país para o estabelecimento de diferentes exigências de acordo com a região e a flexibilização do cumprimento nos casos de propriedades sem RL. O Novo Código Florestal (NCF) de 2012 foi concebido em meio a críticas de ambientalistas e cientistas. Inúmeros trabalhos científicos elencaram os impactos da nova lei em diversos organismos, mesmo durante a elaboração da lei, mas seus apontamentos foram de forma geral ignorados. Entre as principais críticas às mudanças das regras da RL, destacam-se a mudança na escala espacial admitida para compensação de RL, a incorporação das Áreas de Preservação Permanente na RL, a admissão do uso de espécies exóticas para recuperação da RL e a anistia proporcionada para propriedades sem RL.

No Capítulo 2, analisaram-se os efeitos da anistia na RL do Cerrado. Para isso, utilizouse o mapeamento do Projeto de Monitoramento dos Biomas Brasileiros por Satélite (PMDBBS) de forma a quantificar a área desmatada antes de 22/07/2008 (marco temporal para concessão da anistia). Utilizando a delimitação de imóveis particulares do Instituto Nacional de Colonização e Reforma Agrária (INCRA), procurou-se quantificar o número de imóveis e a quantidade de área de RL a ser anistiada, assim como verificar a relação desses com a atividade agropecuária praticada nas propriedades. Dos 37.375 imóveis analisados, um total de 18.932 tem áreas de RL aptas para anistia, perfazendo uma área de $21.483 \mathrm{~km}^{2}$. Há uma grande distorção da preservação da RL entre as Unidades de Federação do Cerrado: enquanto São Paulo possui $84 \%$ das propriedades aptas para a anistia, no Piauí somente $10 \%$ de imóveis encontram-se nestas condições. A atividade agropecuária com maior porcentagem de propriedades com RL preservada foi a rizicultura $(75 \%)$ ao passo que o cultivo de cana apresentou a menor (29\%). Os resultados demonstraram que há uma grande distorção no cumprimento da RL, e que por isso a anistia terá efeitos diferentes em cada região, beneficiando algumas em detrimento a outras. 
No Capítulo 3 foi analisada a mudança da regra na compensação de RL, especificamente em relação à mudança da escala espacial admissível para manter a RL fora da propriedade: antes esta deveria se localizar na mesma microbacia, agora deve se localizar no mesmo bioma. Para simular a composição florística das RLs no bioma foi utilizada a Modelagem de Nicho Climático (MNC) com dados de ocorrência de 119 espécies arbóreas. A partir da combinação de três níveis de microbacia com três níveis de similaridade florística, geraram-se nove cenários propostos para trocas de RL. As microbacias que possuíam similaridade florística foram denominadas Grupo de Microbacias Intercambiáveis (GMIs), onde as trocas de RL podem ser realizadas sem uma perda de espécies expressiva no processo. Considerando-se um cenário com a regra atual e sem adotar nenhum índice de similaridade, observou-se que a perda de espécies poderia representar até $53 \pm 30.3 \%$, atingindo $100 \%$ em alguns casos, o cenário com índice de similaridade com maior perda apresentou $11.3 \pm 7.2 \%$, com perda máxima de $50 \%$ de espécies. Isto demonstra como a regra atual de compensação pode gerar situações onde a RL compensada não possui uma única espécie em comum com a área original. Foram ainda apresentadas métricas para a avaliação dos nove cenários apresentados, sendo uma de custo (área a ser recuperada) e duas de benefícios ambientais (redução da fragmentação da paisagem e número de corpos hídricos com a área de contribuição protegida). O cenário que apresentou melhor custo/benefício foi o Ottobacia 5 com $80 \%$ de similaridade. Concluiu-se que a adoção de uma escala espacial para a compensação de RL deve incorporar um critério de similaridade, de forma a garantir que a área compensada tenha o máximo de espécies em comum com a área original. 


\begin{abstract}
In 2012 the Brazilian Forest Code was modified, changing many of the rules that regulate the conservation of native ecosystems. The objective of this dissertação was to analyze some of the impacts of the new law changes in the Legal Reserve (LR) conservation. Therefore, this dissertação is divided into three chapters.

In the Chapter 1, the amendments made to the LR since its inception, in 1934, through its first review, in 1965, until the last change in 2012 are presented. Among the principal alterations, it emphasizes the change of an estabilished size of the LR across the country to different requirements according to the region and flexibility of the compliance in cases of properties without LR. The New Forest Code (NFC), 2012, was conceived amid criticism from environmentalists and scientists. Numerous scientific studies warned about the impact of the new law on many organisms, even during the drafting of the law, but these observations were generally ignored. Among the main criticisms to change the rules of the LR, we highlight the change in spatial scale allowed for LR compensation, the incorporation of Permanent Preservation Areas in LR, the admission of the use of exotic species for LR recovery and amnesty provided for properties without LR.
\end{abstract}

In Chapter 2, we analyzed the effects of amnesty in the Cerrado LR. For this, we used the Monitoring Project of Brazilian Biomes by Satellite (PMDBBS) to quantify the área deforested before 22/07/2008 (timeframe for granting amnesty). Using the database of private properties from the National Institute of Colonization and Agrarian Reform (INCRA), we quantified the number of properties and the amount of area of LR to be amnestied, as well as verify any relation with agricultural activities practiced in the properties. Of the 37,375 properties analyzed, a total of 18,932 have suitable LR areas for amnesty, with total area of $21.483 \mathrm{~km}^{2}$. There is a large distortion of preservation of LR between Brazilian States with áreas of Cerrado: while São Paulo has $84 \%$ of the properties suitable for the amnesty, in Piauí only $10 \%$ of properties had these conditions. The agricultural activity with the highest percentage of properties with preserved LR was rice cultivation (75\%) while the sugar cane cultivation had the lowest (29\%). The results showed that there is a large distortion in LR compliance, and therefore amnesty would have different effects in each region, benefiting some over others. 
In Chapter 3, we analyzed the rule change in LR compensation, specifically in relation to the permissible spatial scale to keep the LR outside the property: in the old legislation it should be located in the same watershed, but now in the same biome. To simulate the floristic composition of LRs in the biome we used Climate Niche Modeling (CNM) with occurrence data for 119 tree species. From the combination of three levels of watershed with three levels of floristic similarity we generated nine scenarios proposed for LR changes. The watersheds that had floristic similarity were named Group of Interchangeable Watersheds (GIWs), and in these LR changes could be made without a significant loss of species in the process. While the exchange of LR without adopting any similarity index (simulating the rule of NFC) averaged up to a loss of $53 \pm 30.3 \%$ of species, reaching $100 \%$ in some cases, the use of scenarios with similarity index with the largest loss presented $11.3 \pm 7.2 \%$, with a maximum loss of $50 \%$ of species. This demonstrates how the current rule of compensation may lead to situations where the offset LR does not have a single species in common with the original area. Metrics were also presented for the evaluation of the nine presented scenarios being one of cost (area to be recovered) and two of environmental benefits (reduction of landscape fragmentation and the number of water bodies protected). The scenario that presented the best cost / benefit was Ottobacia 5 with $80 \%$ similarity. It was concluded that the adoption of a spatial scale for LR compensation must incorporate a similarity criterion, in order to ensure that the offset area has the maximum number of common species with the original area. 


\section{CAPÍTULO 1}

A Reserva Legal no Código Florestal de 1934 a 2012 


\section{A Reserva Legal no Código Florestal de 1934 a 2012}

\section{INTRODUÇÃO}

Toda propriedade rural no Brasil deve possuir um percentual mínimo de cobertura vegetal nativa, que varia de acordo ao bioma na qual se insere. Esta obrigatoriedade, definida por lei, é denominada de Reserva Legal. As Reservas Legais das propriedades rurais são hoje responsáveis por abrigar a maior parte da vegetação protegida do Brasil, possuindo área maior do que as Unidades de Conservação, espaços públicos geridos pelo governo com a finalidade de conservar os recursos naturais. Aproximadamente $24 \%$ do território nacional é protegido por RLs, ao passo que somente $20 \%$ é conservado sob a forma de Unidades de Conservação e Terras Indígenas (SPAROVECK et al. 2011). Este modelo de compartilhamento da responsabilidade de proteção da natureza entre o poder público e privado é uma característica importante da legislação ambiental brasileira, e se expressa de forma marcante na definição da Reserva Legal (MEDEIROS et al 2004). A Reserva Legal é instituída através do Código Florestal, principal marco legal ambiental do país (LEWINSOHN 2010), que hoje se encontra sob a lei 12.651, de 2012 (BRASIL 2012). O Código Florestal sofreu diversas alterações desde sua primeira edição e um dos institutos legais que apresentou mais mudanças ao longo do tempo foi a Reserva Legal, apesar de nunca ter perdido seu conceito primordial de reservar uma parte de toda propriedade privada rural para abrigar um percentual mínimo de vegetação nativa.

\section{Histórico da Reserva Legal no Brasil}

A primeira concepção de Reserva Legal foi instituída no primeiro Código Florestal, de 1934, como foi denominado o decreto 23.793. No ano de 1934 foram 
promulgadas diversas leis com cunho ambiental, como o Código de Águas (Decreto 24.643), de Caça e Pesca (Decreto 23.672) e o Decreto de Proteção de Animais (Decreto 24.645), porém o Código Florestal foi o mais importante, por estabelecer as bases da proteção dos principais ecossistemas brasileiros (MEDEIROS et al. 2004). O conceito de se limitar o desmatamento na propriedade rural privada foi expresso através do artigo 23, que estabelecia que "Nenhum proprietario de terras cobertas de mattas poderá abater mais de tres quartas partes da vegetação existente, (...)” (BRASIL 1934), apesar de não ter especificado um nome para a área que deveria ser preservada. A preocupação principal na época era disciplinar o desmatamento das florestas para evitar a escassez de madeira (OLIVEIRA E BACHA 2003).

Em 1965 o Código Florestal sofreu sua primeira reforma no que viria a se chamar na época de Novo Código Florestal, sob a lei 4.771. O responsável por encaminhar o primeiro projeto de lei, o então Ministro da Agricultura Armando Moreira Filho, endossou a restrição ao desmatamento nas propriedades privadas, passando a denominar estas áreas como Reserva Florestal (MONTEIRO FILHO 1962). A respeito desta restrição ao uso das propriedades rurais, o Ministro as comparou às restrições impostas pela lei às construções urbanas, que tem limites no número de andares e nas áreas de ventilação (MONTEIRO FILHO 1962). A destinação de parte da propriedade para conservação da vegetação nativa teria, segundo o documento, respaldo na função social que as propriedades exercem (MONTEIRO FILHO 1962). A lei aprovada perpetuou a restrição de uso de parte das propriedades privadas, porém estabelecendo diferentes proporções de acordo com as regiões e grau de desmatamento das propriedades. Segundo o texto, em seu artigo 16 (BRASIL 1965) “(...) nas regiões Leste Meridional, Sul e Centro-Oeste, esta na parte sul, as derrubadas de florestas nativas, primitivas ou regeneradas, só serão permitidas, desde que seja, em qualquer caso, 
respeitado o limite mínimo de $20 \%$ da área de cada propriedade”. Nas propriedades já desmatadas, a lei proibia novos desmatamentos, porém permitia o uso da vegetação remanescente para “(...)apenas a extração de árvores para produção de madeira.”, o que concebia um caráter utilitário nestas áreas. Ratificando este conceito, a lei estabelecia que na região Sul do país, em locais de ocorrência da espécie arbórea Araucária (Aracucaria angustifolia), que possui um conhecido potencial madeireiro, as áreas não poderiam ser “(...) desflorestadas de forma a provocar a eliminação permanente das florestas, tolerando-se, sòmente a exploração racional destas (...)com a garantia de permanência dos maciços em boas condições de desenvolvimento e produção;”. Em relação às áreas que ainda não haviam sido desmatadas, o percentual de Reserva Florestal era ainda maior, conforme se observa: "Nas áreas ainda incultas, sujeitas a formas de desbravamento, as derrubadas de florestas primitivas, nos trabalhos de instalação de novas propriedades agrícolas, só serão toleradas até o máximo de 50\% da área da propriedade”. Na região Norte e na parte Norte do Centro Oeste, o desmatamento das propriedades só poderia ser realizado em até $50 \%$ da área, conforme estabelecia o artigo 44 (BRASIL 1965). Portanto, podemos notar neste momento duas características peculiares da Reserva Legal já vigentes nesta época: estabelecimento de diferentes normas em cada região, e um caráter utilitário destas áreas, mediante um uso racional dos recursos florestais, porém ainda subsistia o nome de Reserva Florestal.

O nome Reserva Legal somente foi adotado em 1989, através da Lei 7.803 (BRASIL 1989), que alterou diversos artigos da Lei 4.771. A partir desta normativa, a área restritiva ao desmatamento passou a se denominar Reserva Legal, instituindo-se a partir de então a obrigatoriedade de averbação à margem da inscrição da matrícula do imóvel no cartório. 
Apesar de já instituída pela lei desde 1934, a obrigação de possuir Reserva Legal, agora já com este nome, ganha um reforço com a instituição da Política Nacional Agrícola, através da Lei 8.171, de 1991, que em seu artigo 99 estabelecia que a partir do ano seguinte todo proprietário rural que não tivesse Reserva Florestal Legal (assim era chamada nesta lei) deveria recuperá-la mediante o plantio de um trinta avos da área por ano. Um parágrafo deste artigo, que proibia a concessão de crédito agrícola a quem não cumprisse essa recomposição, foi vetado (BRASIL 1991). Em 1996, através da Medida Provisória 1.511, específica sobre a Região Norte e Norte do Centro Oeste (hoje conhecida como Amazônia Legal), o percentual de Reserva Legal desta região é alterado. Essa foi a primeira de uma série de Medidas Provisórias que alteraram fundamentalmente o dispositivo da Reserva Legal no Brasil entre os anos de 1996 e 2001.

\section{As Medidas Provisórias de 1996 a 2001.}

A Medida Provisória 1.511 foi fruto da divulgação de uma crescente taxa de desmatamento na Amazônia (OLIVEIRA \& BACHA 2003, SIQUEIRA \& NOGUEIRA 2004, STICKLER et al. 2013), e do temor do governo brasileiro com a repercussão internacional deste fato (BENJAMIM 2000, SILVA et al 2010). Entre os anos de 1994 e 1995 os dados do Instituto Nacional de Pesquisas Espaciais (INPE) divulgados sobre o desmatamento da Amazônia, apresentaram um aumento de $95 \%$ na área desmatada no bioma (http://www.obt.inpe.br/prodes/prodes_1988_2013.htm).

Em consequência disto, portanto, a normativa passou a exigir que nas regiões Norte e Norte do centro Oeste $80 \%$ das propriedades fossem preservadas em locais com fitofisionomias florestais. As demais fitofisionomias destas regiões permaneceriam com o percentual anterior de 50\%. Um importante marco desta Medida Provisória foi o delineamento geográfico do que seria a Região Norte do Centro Oeste, estabelecendo 
através de coordenadas geográficas as áreas objetos desta normativa. Apesar da reação negativa de setores ligados ao agronegócio na época (BENJAMIN 2000, OLIVEIRA E BACHA 2003, STICKLER et al. 2013), esta Medida Provisória foi reeditada e substituída por outras de teor similar diversas vezes. Nas muitas reedições e alterações (67 em 15 anos), foram sendo incorporados novos elementos ao dispositivo da Reserva Legal. Alguns dos principais foram a Medida Provisória 1.605-30, de 1998, que passou a permitir que áreas onde não houvesse vegetação suficiente para compor a Reserva Legal pudessem compensar adquirindo Reserva Legal em outra propriedade; Medida Provisória 1.736-31, de 1998, que reduziu a Reserva Legal de áreas de Cerrado nas regiões Norte e Norte do Centro Oeste para 20\% (mantendo os demais percentuais nas outras fisionomias) e admitiu o uso de espécies exóticas na recomposição da Reserva Legal, o que dependeria de posterior regulamentação; e a Medida Provisória 1.956-50 de 2000, a primeira a não dispor somente sobre a Amazônia Legal, mas sobre todo o país, e que definiu o conceito de Reserva Legal pela primeira vez. Nota-se nesta definição a incorporação de conceitos preservacionistas (OLIVEIRA E BACHA 2003), porém sem perder o caráter original de uso econômico destas áreas, conforme se depreende da definição de Reserva Legal estabelecida por esta lei: "área localizada no interior de uma propriedade ou posse rural, excetuada a de preservação permanente, necessária ao uso sustentável dos recursos naturais, à conservação e reabilitação dos processos ecológicos, à conservação da biodiversidade e ao abrigo e proteção de fauna e flora nativas.". A Medida Provisória 1956-50 trouxe ainda cinco importantes alterações no regime da Reserva Legal: passou a definir a Região Norte e Norte do Centro Oeste como Amazônia Legal, aumentou a Reserva Legal do Cerrado localizado na Amazônia Legal para 35\%, definiu pela primeira vez uma Reserva Legal específica para áreas de Campos Gerais, que seria de $20 \%$, admitiu a incorporação de APPs na 
Reserva Legal em casos específicos, e ainda estabeleceu como a Reserva Legal poderia ser constituída de espécies exóticas em pequenas propriedades. A utilização de espécies exóticas nas demais propriedades ainda dependeria de regulamentação do Conselho Nacional de Meio Ambiente, o CONAMA.

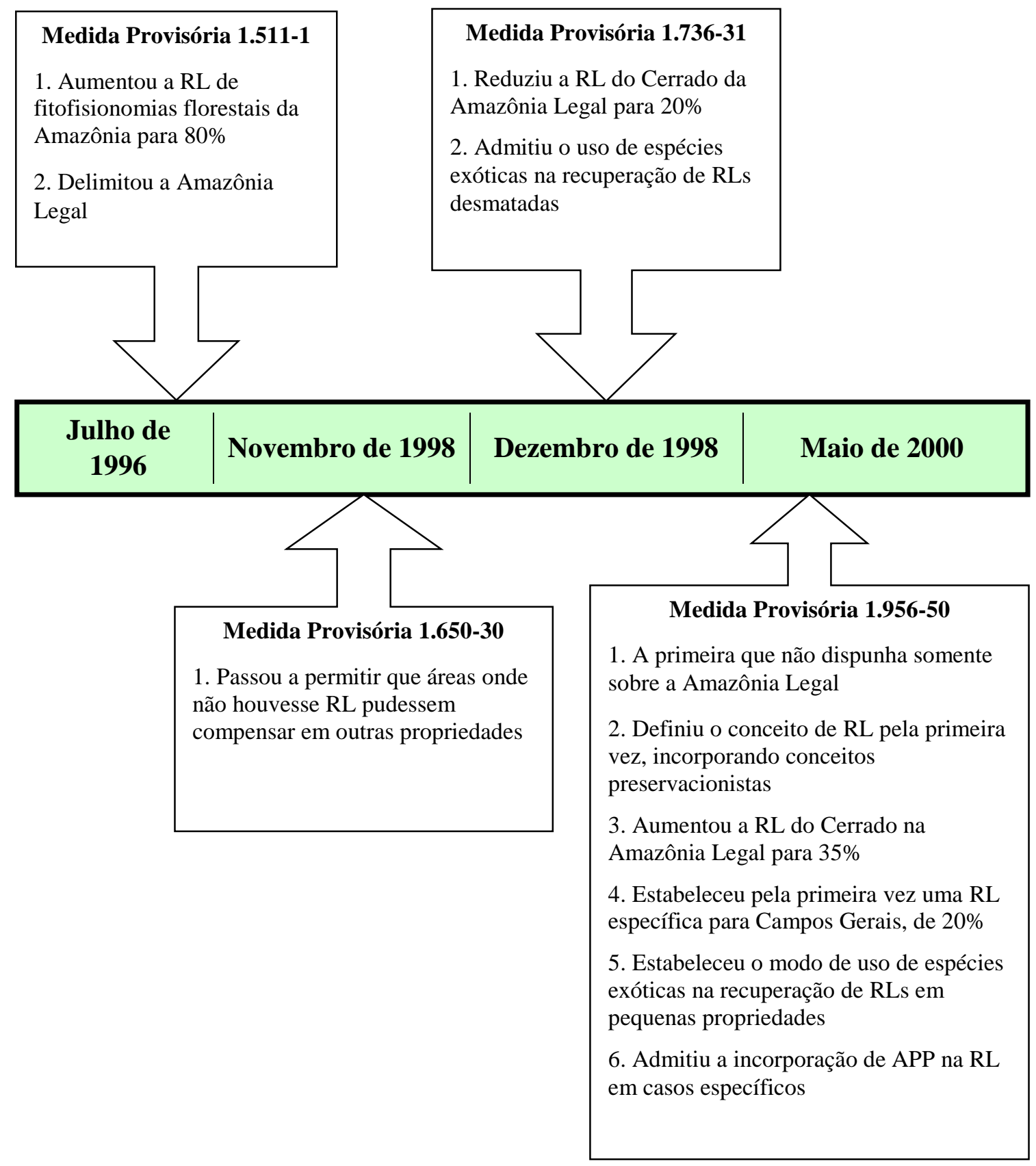

Figura 1. Algumas das Medidas Provisórias editadas e suas principais alterações na Reserva Legal ao longo do tempo. 
Finalmente, foi editada em 2001 a última Medida Provisória, 2.166-67, que não trouxe alterações significativas às anteriores, e que vigorou até a segunda revisão do Código Florestal, em 2012.

\section{O Novo Código Florestal de 2012}

Em 19/10/1999, foi apresentado na Câmara dos Deputados o Projeto de Lei 1876 de autoria do Deputado Sérgio Carvalho, com o objetivo de alterar o Código Florestal. Após inúmeros trâmites naquela casa, em Outubro de 2009 foi constituída uma Comissão Especial destinada a proferir um parecer sobre o Projeto de Lei, com o então Deputado Federal Aldo Rebelo sendo designado como relator. A necessidade de efetuar mudanças na legislação neste momento foi fruto da pressão de setores do agronegócio em resposta às ações governamentais de fiscalização cada vez mais fortes e exigência do próprio mercado por produtos legalmente responsáveis (NEPSTAD 2014). Em Junho de 2010, o Deputado apresenta o relatório na Câmara, com sua proposta para a nova legislação. O relatório do Deputado Aldo Rebelo (REBELO 2010) é um importante documento para entender a ideologia que sustenta a nova legislação. Diferente do relatório de Armando Monteiro Filho (MONTEIRO FILHO 1962), em nenhum momento o texto enfatiza a importância da preservação dos recursos naturais e os impactos que a degradação destes pode causar nos ecossistemas brasileiros. O relatório busca justificar a mudança da lei a partir de três ideias principais: a de que a lei atual é injusta, inviabilizando a agricultura; a de que a lei atual serve a interesses multinacionais que utilizam o ambientalismo para uma suposta questão comercial, questionando a veracidade dos estudos de mudanças climáticas; e de que a degradação ambiental é um processo natural, necessário e inevitável do progresso humano. 
O relatório inicia criticando as excessivas mudanças que o Código sofreu ao longo das décadas, que teriam desconfigurado o espírito da lei anterior. As inúmeras modificações teriam, segundo o autor, posto na ilegalidade $90 \%$ das propriedades rurais do país, e caracterizariam atividades inofensivas como extrair minhocas do solo na beira de um rio como um crime ambiental. Em seguida questiona a retirada de espécies exóticas centenárias de áreas de preservação, sugerindo a naturalização das mesmas, visto que este é um processo no qual “(...)qualquer cidadão pode alcançar com meros cinco anos de residência fixa no país.". Prossegue em sua crítica ao código atual, concluindo que "Ao fim e ao cabo, a legislação ambiental funciona como uma verdadeira sobrecarga tributária, elevando o custo final do produto, já oprimido pelo peso da infraestrutura precária e das barreiras não tarifárias cobradas pelos importadores." Portanto, o antigo código é caracterizado como injusto e confuso, cumprindo apenas um papel de elevar a carga tributária dos produtos agrícolas.

O relatório prossegue em uma dura crítica às ONGs internacionais que defendem interesses ambientalistas no país, que segundo o autor procurariam restringir o crescimento econômico e populacional em nome de um fictício limite do planeta, mas que na verdade objetivariam manter a concentração da riqueza mundial entre os países hegemônicos. O ambientalismo é caracterizado no documento como um produto de interesses internacionais com o objetivo de prejudicar a agricultura e a soberania brasileira. Ressalta então que existem muitas incertezas sobre as mudanças climáticas, o que nos impediria de adotar políticas baseadas nos cenários futuros preconizados pelos cientistas.

Por fim, o relatório alimenta a dicotomia entre a preservação e a produção, caracterizando a preservação como um entrave econômico, e até mesmo um impedimento à ocupação humana. Segundo o autor, "Na paisagem virgem, o homem é 
sempre um intruso que só se pode manter pela força.”. Esta luta, segundo ele, é "Contra o excesso de vitalidade da floresta e contra a desordenada abundância da água dos seus rios. Água e floresta que parecem ter feito um pacto da natureza ecológica, para se apoderarem de todos os domínios da região. O homem tem que lutar de maneira constante contra esta floresta que superocupou todo o solo descoberto e que oprime e asfixia toda a fauna terrestre, inclusive o homem, sob o peso opressor de suas sombras densas, das densas copas verdes de seus milhares de espécimes vegetais, do denso bafo de sua transpiração.”. Esta passagem contrasta de maneira marcante com o discurso do relatório de Monteiro Filho (1962), que ressaltava a função das florestas na proteção de terrenos frágeis e nascentes, no abastecimento de madeira, na manutenção da fertilidade do solo e na regulação climática, enfatizando a importância do meio ambiente para nossa própria espécie, conforme trecho final de seu relatório: "Quando cada brasileiro souber o que representa uma floresta, como fator de sua própria sobrevivência e de seu bem estar, poderemos, então, abolir as penalidades, (...)”. As mudanças geradas no Novo Código Florestal de 2012 refletem o discurso do relatório, implementando diversos aspectos que flexibilizaram a proteção ambiental do país, em especial no dispositivo da Reserva Legal. Segundo Silva et al. (2010) e Trindade (2010), as alterações propostas pelo Deputado refletiram o interesse dos setores do agronegócio, sem considerar a proteção da biodiversidade do país.

\section{As mudanças do Novo Código Florestal na Reserva Legal}

O Novo Código Florestal, lei 12.651, foi promulgado em 25 de Maio de 2012, porém sofreu diversas alterações em 17 de Outubro de 2012 através da Lei 12.727. Uma característica marcante da votação que aprovou a lei é que ela recebeu votos favoráveis tanto dos governistas quanto da oposição, um consenso difícil de atingir em outras leis (a votação pode ser acessada em http://www2.camara.leg.br/camaranoticias/ 
noticias/MEIO-AMBIENTE/197560-CAMARA-APROVA-NOVO-CODIGO-FLORES

TAL-COM-MUDANCA-EM-REGRAS-PARA-APPS.html). A Reserva Legal, nesta terceira versão do Código Florestal, sofreu pequena alteração em sua definição, passando a vigorar com o seguinte texto: "área localizada no interior de uma propriedade ou posse rural, delimitada nos termos do art. 12, com a função de assegurar o uso econômico de modo sustentável dos recursos naturais do imóvel rural, auxiliar a conservação e a reabilitação dos processos ecológicos e promover a conservação da biodiversidade, bem como o abrigo e a proteção de fauna silvestre e da flora nativa;". Nota-se a incorporação do termo "uso econômico" na definição de sua função, reforçando a função utilitária da vegetação. As porcentagens para cada bioma mantiveram-se as mesmas, permanecendo $80 \%$ na Amazônia, 35\% no Cerrado localizado na Amazônia Legal, 20\% nos campos gerais localizados na Amazônia Legal e $20 \%$ no resto do país. O cômputo das Áreas de Preservação Permanente no cálculo da Reserva Legal, antes permitido somente a pequenos produtores em casos específicos, foi objeto de maior flexibilização, podendo ser utilizado por qualquer imóvel, desde que não implique no desmatamento de novas áreas. Também diversos aspectos relacionados principalmente à regularização de propriedades que não possuem vegetação nativa suficiente para compor a Reserva Legal foram modificados. Dois dos mais polêmicos pontos da nova lei, referentes à Reserva Legal, são a chamada anistia e a mudança nas regras de compensação da Reserva em outra propriedade.

\section{A anistia do Novo Código Florestal na Reserva Legal}

Um dos pontos mais polêmicos do Novo Código Florestal foi a chamada anistia aos proprietários que tivessem cometido crimes ambientais. Mas no que consiste exatamente essa anistia? Quem e o que foi anistiado? 
Para responder essa questão, devemos entender como esta anistia está especificada na redação da nova lei. $\mathrm{O}$ cerne do conceito de anistia reside em um novo conceito trazido pela legislação, que é o de “Área Rural Consolidada”. Inexistente nos Códigos anteriores, este conceito está definido no terceiro artigo, inciso IV: “área rural consolidada: área de imóvel rural com ocupação antrópica preexistente a 22 de julho de 2008, com edificações, benfeitorias ou atividades agrossilvipastoris, admitida, neste último caso, a adoção do regime de pousio;". Tanto as Áreas de Preservação Permanente quanto de Reserva Legal que se enquadrem neste conceito, ou seja, que tenham atividades antrópicas anteriores a 22 de Julho de 2008, tem um tratamento diferente no Novo Código Florestal. Antes de entendermos quais são estas diferenças, surge naturalmente uma pergunta: porque foi escolhida esta data de 22 de Julho de $2008 ?$

Segundo alguns autores (SAUER \& FRANÇA 2012) a razão principal reside no fato de que esta foi a data da promulgação do Decreto 6.514, que regulamentou a lei de crimes ambientais (Lei 9.605/98). Este Decreto, que substituiu o anterior (Decreto 3.179/99), passou a considerar crime ambiental não averbar a Reserva Legal (artigo 55). Ressalta-se que o Decreto antigo já considerava crime o desmatamento em áreas de Reserva Legal em 1999 (artigo 39), a obrigação de se averbar a Reserva Legal em cartório foi estabelecida em 1989 (Lei 7.803/89), e a obrigação de se manter Reserva Legal na propriedade, como descrita acima, desde 1934. Portanto, apenas o fato da falta de averbação ter sido considerada crime ambiental pelo Decreto 6.514 justificou a adoção da data de sua promulgação como o marco temporal para caracterização de área rural consolidada, apesar da obrigatoriedade em se preservar a Reserva Legal já existisse bem antes. Devido ao critério controverso adotado, a escolha desta data ensejou discussões no congresso (SENADO 2011) e críticas de diversos atores sociais 
(ver por exemplo http://www.oeco.org.br/guilherme-jose-purvin-de-figueiredo/25432senado-vai-aprovar-areas-de-degradacao-permanente).

Todo o capítulo IV trata das áreas de Reserva Legal no Novo Código, e alguns de seus artigos especificam as áreas objeto de anistia. Algumas áreas que antes deveriam possuir Reserva Legal não precisam mais: em empreendimentos públicos de abastecimento de água e tratamento de esgoto, em áreas adquiridas em empreendimentos de energia elétrica e para implantação de rodovias e ferrovias. Mas é no capítulo VIII, seção III, denominado "Das Áreas Consolidadas em Áreas de Reserva Legal" onde reside todo o escopo da chamada anistia. No artigo 67, a lei define que em toda propriedade que possuía área de até quatro módulos fiscais em 22 de Julho de 2008, a Reserva Legal será constituída da área nativa existente naquela data. Isto corresponde a 90\% dos imóveis rurais brasileiros (SOARES FILHO 2014). O tamanho do módulo fiscal varia em cada município brasileiro, e pode-se acessar os valores no site do Instituto Nacional de Colonização e Reforma Agrária (INCRA). Para exemplificar, uma propriedade com quatro módulos fiscais, em área de Cerrado do município de Pium, Tocantins, onde o módulo fiscal é de 80 hectares (INCRA 2014), tem uma área total de 320 hectares. Supondo que esta possua, desde 2007, uma área de somente 10 hectares de vegetação nativa, estando com o resto da propriedade inteiramente desmatada, esta pequena área remanescente representaria apenas 3,1\% da propriedade, inferior aos $35 \%$ exigidos para Reserva Legal no Bioma Cerrado localizado na Amazônia Legal. Mesmo assim, de acordo com a nova legislação, o proprietário teria que manter somente os 3,1\% de vegetação como Reserva Legal. Os 31,9\%, ou 102 hectares, de vegetação desmatada ilegalmente em sua área de Reserva Legal, estariam anistiados com a nova legislação. Caso a propriedade se encaixe no perfil de pequena propriedade ou posse rural familiar, caracterizado como agricultor que 
não detenha mais do que 4 módulos fiscais, utilize predominantemente mão-de-obra da própria família nas atividades econômicas do seu estabelecimento, tenha percentual mínimo da renda familiar originada de atividades econômicas do seu estabelecimento e dirija seu estabelecimento ou empreendimento com sua família, ou ainda se a propriedade for um assentamento ou projeto de reforma agrária, se tratar de comunidade indígena, quilombola, pescador artesanal, extrativista, pequeno aquicultor ou silvicultor, podem ser computados para efeito de Reserva Legal plantios de árvores frutíferas, ornamentais ou industriais, ainda que exóticas. Isto quer dizer que em uma propriedade sem nenhuma vegetação nativa, que se encaixe nos requisitos acima mencionados, o pomar de frutíferas exóticas, ou uma plantação de eucalipto, podem ser considerados a área de Reserva Legal.

As propriedades com área maior do que quatro módulos fiscais, e que tivessem desmatado sua Reserva Legal antes de 22 de Julho de 2008, teriam um tratamento diferente: caso o desmatamento tenha sido realizado de acordo com a legislação da época, sua Reserva seria constituída do percentual exigido pela legislação vigente. Ou seja: em 1999 a Reserva Legal do Cerrado na Amazônia Legal era de 20\%. Se uma propriedade com área maior do que quatro módulos fiscais do município de Pium (Tocantins), localizada no Cerrado, tivesse realizado o desmatamento de $80 \%$ da propriedade em 1999, mesmo que hoje a Reserva Legal da região seja de 35\%, esta propriedade terá que manter somente $20 \%$ de Reserva Legal, visto que na época do desmatamento era esse o percentual estabelecido. Caso o desmatamento tenha sido realizado em desacordo com a legislação da época, ainda assim o proprietário pode se regularizar, contanto que tenha realizado o desmatamento de sua Reserva até 22 de Julho de 2008. Neste caso, ele pode optar por três alternativas para sua regularização: recompor a Reserva Legal, permitir a regeneração natural ou compensar em outra 
propriedade. Portanto, todo e qualquer desmatamento na Reserva Legal realizado antes de 22 de Julho de 2008 pode ser regularizado de acordo com o Novo Código Florestal, de diferentes formas (Tabela 1).

Tabela 1. Regularização de áreas de Reserva Legal (RL) desmatadas até 22/07/2008.

Desmatou de acordo com a legislação vigente na época
Desmatou em desacordo com a legislação vigente na época
Acima de quatro módulos fiscais

Sua RL é determinada pela
legislação vigente na época do desmatamento
Deve recompor, permitir regeneração natural ou compensar a RL com os percentuais atualmente exigidos

Percebe-se que a regularização das Reservas Legais brasileiras irá depender da determinação da época na qual a propriedade foi desmatada, visto que se estabeleceram diferentes regras para os marcos temporais das mudanças de percentuais exigidos para Reserva e principalmente para a data de 22 de Julho de 2008. Sem dúvida será um desafio para os órgãos ambientais promoverem este tipo de análise para cada propriedade, a fim de determinar quanto é o percentual adequado de Reserva e se a propriedade pode ser regularizada segundo os ditames do Novo Código (SPAROVECK et al. 2011).

As formas de regularização da $\mathrm{RL}$ em propriedades acima de quatro módulos

\section{fiscais}


Apesar de ter a sua sanção suspensa, para a regularização das propriedades acima de quatro módulos fiscais, e que desmataram até a data limite determinada, o proprietário deve realizar umas das três alternativas estabelecidas na lei, quais sejam: recompor, regenerar ou compensar.

A recomposição deve ser realizada em até 20 anos, sendo que a cada dois anos devem ser recuperados $1 / 10$ da área. A legislação permite que até $50 \%$ da área seja recuperada com espécies exóticas, combinadas com espécies nativas de ocorrência regional, assegurando a exploração econômica destas espécies. Visto não estabelecer uma composição mínima de espécies nativas (ou máxima de exóticas), e não especificar que as mesmas devem ser de hábito arbóreo, um consórcio da espécie exótica de cultivo anual Soja (Glycine max) com a espécie arbórea nativa Pequi (Cayocar sp.), plantado de 20 em 20 metros, poderia constituir 50\% da Reserva Legal de uma propriedade do Cerrado, sendo assegurada a exploração econômica desta área. A regeneração natural não possui uma metodologia especificada na lei.

Já a compensação pode ser realizada de quatro formas: com a aquisição de Cota de Reserva Ambiental (CRA), arrendamento de área de servidão ambiental ou de Reserva Legal, doação ao poder público de área localizada no interior de Unidade de Conservação que esteja pendente de regularização fundiária ou através da aquisição de outro imóvel, com vegetação nativa estabelecida ou em processo de recuperação, localizada no mesmo Bioma.

A Cota de Reserva Ambiental corresponde a uma área de vegetação nativa que exceda o percentual exigido para a Reserva Legal nas propriedades, podendo ser utilizado para regularizar outra propriedade, desde que localizada no mesmo Bioma. A servidão tem praticamente a mesma função, só que pode ser arrendada por um período determinado. Já a aquisição de outro imóvel tem a característica de ser do mesmo 
proprietário. Nas três modalidades a área a ser utilizada como Reserva Legal deve ser equivalente em extensão e localizar-se no mesmo Bioma da propriedade original e, caso fora do Estado, estar localizada em área prioritária para conservação.

A compensação de Reserva Legal em outra propriedade é prevista desde 1998, quando da edição da Medida Provisória 1.605-30. Esta legislação permitiu que propriedades que não tivessem vegetação nativa para compor sua Reserva Legal pudessem compensa-la em outra área, desde que pertencesse ao mesmo ecossistema, estivesse localizada no mesmo Estado e fosse de importância ecológica igual ou superior à área a ser compensada. Em 2000, através da Medida Provisória 1.956-50, estabeleceu-se que além dos demais critérios, a Reserva deveria localizar-se na mesma microbacia, e que somente propriedades que tivessem desmatado a Reserva Legal antes de 14 de Dezembro de 1998 poderiam receber o benefício da compensação. Estes critérios perduraram até a promulgação do Novo Código Florestal. Nas novas regras a propriedade onde será compensada a Reserva Legal precisa apenas pertencer ao mesmo Bioma da propriedade sem RL, o que na prática significa que uma propriedade desmatada no Cerrado do interior de São Paulo poderá ter sua RL alocada no Cerrado do sul do Maranhão. Além disso, o marco temporal adotado passou a ser 22/07/2008. Portanto, nota-se na nova legislação uma flexibilização tanto nos critérios para escolha da área como no marco temporal do desmatamento da Reserva Legal (Tabela 2). 
Tabela 2. Mudanças nas regras de compensação de Reserva Legal.

\begin{tabular}{|c|c|c|}
\hline $\begin{array}{l}\text { Versões do Código } \\
\text { Florestal }\end{array}$ & $\begin{array}{l}\text { Data limite para o } \\
\text { desmatamento da } \\
\text { Reserva Legal }\end{array}$ & $\begin{array}{l}\text { Critérios para escolha da } \\
\text { área onde será alocada a } \\
\text { Reserva Legal da } \\
\text { propriedade }\end{array}$ \\
\hline \multirow{4}{*}{$\begin{array}{l}\text { Antigo Código Florestal } \\
\text { Lei } 4.771 / 65\end{array}$} & \multirow{4}{*}{$14 / 12 / 1998$} & $\begin{array}{l}\text { 1. Equivalente } \\
\text { importância } \\
\text { ecológica }\end{array}$ \\
\hline & & $\begin{array}{l}\text { 2. Equivalente } \\
\text { extensão }\end{array}$ \\
\hline & & $\begin{array}{l}\text { 3. Pertencer ao mesmo } \\
\text { ecossistema }\end{array}$ \\
\hline & & $\begin{array}{l}\text { 4. Localizada na } \\
\text { mesma microbacia }\end{array}$ \\
\hline \multirow{3}{*}{$\begin{array}{l}\text { Novo Código Florestal } \\
\text { Lei 12.651/12 }\end{array}$} & \multirow[t]{3}{*}{$22 / 07 / 2008$} & $\begin{array}{l}\text { 1. Equivalente } \\
\text { extensão }\end{array}$ \\
\hline & & $\begin{array}{l}\text { 2. Localizada no } \\
\text { mesmo bioma }\end{array}$ \\
\hline & & $\begin{array}{l}\text { 3. Se fora do Estado, } \\
\text { localizada em áreas } \\
\text { prioritárias }\end{array}$ \\
\hline
\end{tabular}

Estas mudanças em relação à Reserva Legal além das outras envolvendo Áreas de Preservação Permanente, incêndios florestais e outros aspectos da legislação ambiental foram alvo de inúmeras discussões na sociedade civil e publicações científicas, mesmo ainda na fase de discussão do projeto de lei. Na comunidade científica, em particular, muitos foram os artigos e publicações destinadas a discutir os possíveis impactos da flexibilização que se anunciava na lei.

A reação da comunidade científica às mudanças no Código Florestal, com enfoque na Reserva Legal 
Após a apresentação do Projeto de Lei 1.876 em 19/10/1999, que viria a se tornar o Novo Código Florestal após 13 anos, diversos pesquisadores publicaram artigos analisando as mudanças propostas. Fearnside (2000) já alertava para as consequências em se permitir o uso de espécies exóticas para compor a Reserva Legal, afirmando que este mecanismo só atenderia a um propósito puramente comercial. A compensação de Reserva Legal em outra propriedade também foi alvo de crítica, enfocando o aspecto de que ao se permitir que propriedades tivessem Reserva Legal localizadas em outras, a sociedade civil não conseguiria contribuir com a fiscalização neste aspecto, pois mesmo que propriedades estivessem inteiramente desmatadas poderiam estar legalizadas. Chamando a atenção para a função central de uso sustentável e conservação da biodiversidade desempenhada pelas Reserva Legais, Metzger (2002) levanta dois importantes questionamentos a serem respondidos pela ciência: qual é a extensão ideal da Reserva Legal que permita o uso sustentável e a conservação da biodiversidade, e qual é a disposição ideal das Reservas que otimize a proteção da biodiversidade. Utilizando-se da teoria da percolação, o autor afirma que as paisagens da Amazônia devem possuir um mínimo de $60 \%$ de vegetação nativa preservada para possibilitar a conectividade entre os fragmentos, e que em todos os Biomas deve-se promover a agregação dos fragmentos, formando grandes áreas com Reservas contíguas, o que minimizaria o risco de extinção das espécies. Em outro estudo (METZGER 2010), o mesmo autor analisa se os percentuais estabelecidos para Reserva Legal tem respaldo no conhecimento científico atual. Além de sustentar a porcentagem mínima de $60 \%$ para a região Amazônica, utilizando-se dos argumentos citados acima, o autor sugere para as demais regiões, mais intensamente ocupadas, que se aplique o limiar de fragmentação. Este seria um percentual mínimo de cobertura vegetal abaixo do qual os efeitos da fragmentação se somariam aos efeitos da perda de habitat, tendo conseqüência deletéria 
nas populações e na diversidade biológica. O limiar proposto seria de 30\%, e, como se considera que há uma média de 10\% de APPs nas propriedades, uma Reserva Legal de $20 \%$ ao ser somada às APPs atingiria o limiar proposto. $\mathrm{O}$ autor desaconselha ainda o uso de espécies exóticas na Reserva Legal, devido ao fato de que plantações destas abrigarem menor diversidade biológica do que as florestas nativas (METZGER 2010).

A partir da divulgação em 2010 do Relatório do Deputado Aldo Rebelo (REBELO 2010) se acentuou o número de publicações a respeito das alterações propostas. O periódico científico da Fapesp Biota Neotropica dedicou grande parte de uma edição (Volume 10 número 04) a artigos debatendo as consequiências das mudanças do Código.

Ab’Sáber (2010) chamou a atenção para a enorme heterogeneidade do território brasileiro, e a necessidade de uma nova legislação que abranja todas as diferentes formações naturais do Brasil. Por isso, sugere que ao invés de um Código Florestal, se pense em um Código da Biodiversidade, que desta forma não enfoque apenas as formações ditas florestais, como a Amazônia e Mata Atlântica, mas que também estabeleça proteção própria às formações nos domínios da Caatinga, Cerrado, Pantanal, Pradarias do Sul e demais formações. Já Casatti (2010) descreve potenciais impactos na ictiofauna, devido a uma possível diminuição da vegetação nativa nas bacias hidrográficas, o que poderia comprometer a qualidade dos corpos hídricos com o aumento do assoreamento. Em um estudo sobre os impactos na avifauna, Develey et al. (2010) enfatizam a diferença entre as comunidades de aves que habitam áreas de matas ciliares e áreas secas, o que os levam a concluir que tanto as APPs como as Reservas Legais preservam espécies específicas de cada ambiente, portanto ambas as tipologias devem ser preservadas. A existência de Reservas Legais, prosseguem os autores, são de extrema importância para a avifauna, que precisa de fragmentos espalhados na paisagem 
que conectem os grandes maciços preservados, normalmente sob a forma de Unidades de Conservação. Finalmente, os autores consideram que a compensação de Reservas Legais fora das propriedades deve presumir uma análise cuidadosa, devido ao padrão de distribuição geográfica das espécies, especialmente as endêmicas.

Ressaltando a importância das borboletas como espécies indicadoras, Freitas (2010) prevê a possível perda de espécies deste grupo com o mecanismo de compensação de Reservas, visto que alguns ambientes onde ocorrem espécies específicas podem ser inteiramente desmatados. O autor também enfatiza a importância da preservação tanto de APPs quanto de Reservas, dada a heterogeneidade que estes ambientes representam. Analisando os impactos sobre os répteis, Marques et al. (2010) concluem também que devido à alguns gêneros deste grupo possuírem espécies que raramente co-ocorrem em uma mesma área, mecanismos de compensação de Reserva deveriam ocorrer dentro de microbacias, a fim de se preservar a variação da composição de espécies entre áreas. Em relação ao uso de espécies exóticas na Reserva, os autores alertam para o fato de que a maioria das espécies de répteis brasileiros não é capaz de sobreviver nestes ambientes, se tornando um fator de perda de habitat para estas. Os autores ainda enfatizam a importância da manutenção de Reservas Legais, exemplificando que no Bioma Cerrado poucas UC's se localizam em áreas planas de topos de chapada, apesar de que boa parte da riqueza de lagartos do Bioma se concentra justamente nestas áreas, estando desta forma protegida apenas por Reservas Legais.

Galetti et al. (2010), analisando o impacto das mudanças da lei em mamíferos, ressaltam dois importante papéis das Reservas neste grupo: aumentam a área de habitat disponível e facilitam a movimentação das espécies de maior porte funcionando como trampolins ecológicos. Portanto, qualquer medida que diminua a área de Reserva Legal do país pode levar a uma perda da biodiversidade neste grupo. Cita ainda que em 
plantações de espécies exóticas diversos estudos apontam para um menor número de espécies do que em florestas nativas, portanto a utilização destas espécies na composição da Reserva Legal pode levar a quedas populacionais e um declínio local das espécies do grupo.

Nos anfíbios, relatam Toledo et al. (2010), a utilização de espécies exóticas na Reserva Legal também teria um impacto negativo, citando diversas relações espécieespecíficas entre anfíbios e plantas nativas. O estudo aponta ainda que dentro de um mesmo Bioma há variação na distribuição geográfica das espécies deste grupo, portanto a compensação de Reserva Legal nesta escala espacial poderiam acarretar a extinção local de algumas espécies em áreas totalmente desmatadas. Os autores ainda ressaltam conseqüências danosas deste processo de extinção local do grupo, enfatizando o papel ecológico no controle de insetos (o que pode levar a um aumento de pragas agrícolas), na manutenção de qualidade hídrica e também na importância deste grupo para a indústria farmacêutica.

Em relação às espécies de abelhas, Imperatriz-Fonseca \& Nunes-Silva (2010) relatam a importância destas para a produção agropecuária, através da polinização, e a necessidade da manutenção de áreas preservadas para a sobrevivência das espécies do grupo. Portanto, qualquer medida que reduza a quantidade de vegetação nativa nas propriedades afeta, segundo as autoras, a própria produção agropecuária, devido ao declínio de espécies de abelhas e a conseqüente diminuição da polinização realizada por estas. Neste sentido, Ribeiro \& Freitas (2010) também afirmam que a própria produção agropecuária seria afetada com as alterações propostas para o Código, visto a possibilidade de se formarem extensas áreas sem vegetação nativa devido ao mecanismo de compensação de Reserva fora da propriedade, o que diminuiria a oferta de serviços ecossistêmicos como a citada polinização e outros como o controle 
biológico de pragas e oferta de água. Em relação a este último aspecto, Tundisi \& Tundisi (2010) enfatizam a importância das florestas para a manutenção do ciclo hidrológico, chamando a atenção para os altos custos envolvidos no tratamento de água provinda de bacias hidrográficas desmatadas.

Apesar destes impactos negativos na própria produção agropecuária, o setor agrícola seria supostamente o mais beneficiado, ao menos a curto prazo, com as mudanças do Código, conforme enfatiza o relatório do Deputado Aldo Rebelo (REBELO 2010). Mas será que o cumprimento do Código antigo realmente inviabiliza a produção agropecuária?

Para responder a esta questão, alguns pesquisadores se debruçaram sobre o tema e chegaram a conclusões que em parte desmistificam esta suposta dicotomia entre o cumprimento do Código anterior e a viabilidade da produção agropecuária do país. Brancalion \& Rodrigues (2010) realizaram um estudo de caso com o setor canavieiro de São Paulo que, segundo os autores, possui intenso uso do solo com grande impacto ambiental e por isso o cumprimento do Código anterior deveria representar uma forte limitação em sua produção. Ressaltando a grande variação entre as propriedades analisadas (1.961 propriedades com área total de 533.097 ha) em relação ao cumprimento do Código antigo, os autores observaram que as APPs ocupadas representavam somente $1,6 \%$ da área total ocupada pela cultura. Já o déficit de Reserva Legal totalizava $6,4 \%$ da área ocupada pela cultura, que ainda assim poderiam ser compensados dentro da mesma microbacia. Os autores atentam ainda para o fato de que os recentes ganhos em produtividade no setor permitiriam manter o mesmo nível de produção em áreas menores, portanto possibilitando o pleno atendimento ao Código anterior. Sparovek et al. (2010) utilizaram dados de um mapeamento do desmatamento de 2002, e concluíram que o déficit de Reserva Legal varia entre os Biomas, indo de 
menos que $0,1 \%$ no Pantanal a $34 \%$ na Amazônia Legal, evidenciando uma grande variação no estado da vegetação das Reservas Legais nos Biomas. O estudo demonstra que em um Bioma com intensa ocupação agrícola como o Cerrado o déficit de Reserva Legal na data analisada era de apenas 3,4\%. Importante frisar que os autores consideraram para os cálculos apresentados que toda a área fora de UC's e Terras Indígenas constituem-se em áreas particulares, o que nem sempre é verdade, principalmente na região Amazônica. Soares Filho et al. (2014) demonstraram que menos de $1 \%$ da área agrícola do país ocupa APPs. Já Martinelli et al. (2010) realizaram um estudo sobre a agropecuária brasileira comparando-a com a praticada nos Estados Unidos e União Européia, a fim de analisar se o antigo Código Florestal realmente se configurava como um entrave ao desenvolvimento do setor. Os autores concluíram que diversos aspectos como a distribuição desigual de terras, restrição de crédito agrícola e falta de investimentos em infraestrutura para escoamento da produção, entre outros, seriam mais deletérios à produção agropecuária nacional do que a aplicação da legislação. Ressaltaram ainda que um pequeno aumento na baixa produtividade das pastagens brasileiras, tornando áreas de pastagens disponíveis para ocupação da agricultura sem diminuir a produção pecuária, poderia aumentar em quase 100\% a área atualmente ocupada pelo setor agrícola, sem necessidade de desmatamento em áreas preservadas. Compartilhando desta mesma ideia, Sparovek et al. (2011) enfatizam que a tecnologia necessária para este aumento de produtividade nas pastagens é de simples adesão, porém afirmam que a supressão de florestas para implantação de pastagens pouco produtivas é rentável no país, e que portanto a suposta restrição do Código ao desenvolvimento da agropecuária serve apenas para justificar a manutenção destes espaços pouco produtivos e acobertar as verdadeiras razões que levam ao aumento da expansão agrícola. A ocupação das terras com pastagem, prosseguem os autores, é a 
consequência e não a verdadeira causa do desmatamento, que teria outros reais vetores como o mercado dos produtos madereiros (lenha, carvão e toras), valorização imobiliária de terras desmatadas, ausência de valorização da vegetação nativa, entre outros. Para os autores, o discurso da inviabilidade da atividade agropecuária proporcionada pela legislação visa criar uma ideia mais aceitável para a mudança da legislação, ocultando as verdadeiras razões acima elencadas.

Desta forma, pode-se depreender destes estudos que o déficit de Reserva Legal em algumas regiões não é tão significativo a ponto de uma possível recuperação destas áreas inviabilizar a agricultura, e que a expansão agropecuária pode não ser a única razão pela qual se pretendeu mudar a legislação. Certamente uma análise mais detida sobre a realidade do cumprimento da antiga legislação prescindiria de uma malha fundiária completa do país (SPAROVEK et al. 2011), o que ainda não existe.

Os impactos das alterações realizadas no Código Florestal de fato não se restringem somente aos recursos naturais. Conforme o Comunicado $\mathrm{n}^{\circ} 96$ do Instituto de Pesquisas Econômicas Aplicadas (IPEA 2011), órgão governamental responsável por realizar pesquisas sobre o impacto de políticas públicas, a anistia promovida pelo Novo Código irá beneficiar economicamente o proprietário rural que desmatou inteiramente sua propriedade, pois esta terá um maior valor de mercado do que uma propriedade com parte da vegetação nativa preservada (que cumpriu a antiga legislação), e ainda estará igualmente regularizada. Isto pode alimentar uma sensação de impunidade e inclusive levar os proprietários a acharem que se não cumprirem a legislação poderão ser novamente anistiados no futuro (SOARES FILHO et al. 2014). Já segundo Silva et al. (2011), o mecanismo de compensação de Reserva Legal deverá perpetuar a atual desigualdade na ocupação das terras, sendo que áreas onde o setor agrícola é plenamente desenvolvido (com altas taxas de desmatamento), irão assim permanecer, ao 
passo de que outras áreas, onde a implantação da agricultura poderia trazer algum tipo de desenvolvimento para a região, irão permanecer sem atividades econômicas, abrigando as Reservas compensadas. Esta tendência, se confirmada, irá produzir também outra consequência indesejável: as áreas de Reserva Legal irão se concentrar justamente em locais com baixa pressão de desmatamento, ao invés de protegerem os locais mais desmatados, se tornando assim uma opção mais barata para os proprietários, mas menos efetiva na conservação dos ambientes (SPAROVECK et al. 2012).

Por fim, ressalta-se o consenso de que a alteração do Código Florestal se realizou sem base científica (LEWINSOHN 2010, MAGALHÃES 2010, METZGER et al. 2010, TOLEDO et al. 2010, SILVA et al. 2011, TRINDADE 2011, SPAROVECK 2012, LAUDARES et al. 2013). Este último ponto é compartilhado por muitos autores e muitos dos possíveis impactos advindos da implementação do Novo Código estão amplamente descritos, portanto é necessário que pesquisas sejam continuamente realizadas para um monitoramento e avaliação constantes das mudanças nas dinâmicas de uso dos recursos naturais deste período posterior à promulgação da nova lei. Estas análises se tornam indispensáveis à medida que novas bases cartográficas de dados ambientais são disponibilizadas, o que permite com que as análises feitas sejam qualitativamente cada vez mais acuradas. Ignorada na concepção da legislação, a ciência se torna indispensável para uma constante avaliação que possa apontar melhorias e, mais importante, alertar para os primeiros indícios reais de alguns dos impactos já previstos pelos pesquisadores. O envolvimento da sociedade civil e da comunidade científica são essenciais para o futuro dos recursos naturais do país, que começou a ser definido pelo governo em 25 de Maio de 2012. 


\section{CONCLUSÕES}

Em todos os estudos sobre os impactos em grupos específicos e sobre aspectos negativos provenientes das mudanças no Código Florestal, ressaltam-se quatro dos principais pontos convergentes sobre os impactos da nova legislação:

1. Compensação da RL na escala de bioma: isto pode levar ao estabelecimento de regiões inteiras desmatadas e outras bem distantes preservadas, o que em diversos grupos de organismos pode levar a extinções locais, de acordo com a distribuição geográfica das espécies.

2. Incorporação das APPs dentro da área de Reserva Legal: Também pode afetar algumas espécies, visto que são dois ambientes distintos e algumas espécies ocorrem somente em um destes habitats.

3. Uso de espécies exóticas na Reserva Legal: deverá diminuir o habitat disponível para organismos com relações espécie-específicas desenvolvidas com táxons nativos.

4. Diminuição de cobertura florestal: irá proporcionar a diminuição dos serviços ecossistêmicos como polinização, controle biológico e oferta de água, o que deverá afetar a produção agropecuária.

Por fim, é consenso que a alteração do Código Florestal se realizou sem base científica, apesar de inúmeros estudos analisando diversos aspectos da legislação. 


\section{REFERÊNCIAS BIBLIOGRÁFICAS}

AB'SÁBER, A. N. Do Código Florestal para o Código da Biodiversidade. Biota Neotropica, v. 10, n. 4, p. 332-335, 2010.

BENJAMIN, A. H. DE V. E. A proteção das florestas brasileiras: ascensão e queda do código florestal. Revista de Direito Ambiental, v. 18, p. 21-37, 2000.

BRANCALION, P. H. S.; RODRIGUES, R. R. Implicações do cumprimento do Código Florestal vigente na redução de áreas agrícolas: um estudo de caso da produção canavieira no Estado de São Paulo. Biota Neotropica, v. 10, n. 4, p. 63-66, 2010.

BRASIL. Decreto n. 23.793 de 23 de Janeiro de 1934. Institui o Código Florestal Brasileiro. Rio de Janeiro (RJ), 1934.

Lei n. 4.771 de 15 de Setembro de 1965. Institui o novo Código Florestal. Brasília(DF), 1965.

Lei n. 7.803 de 18 de Julho de 1989. Altera a redação da Lei n. 4.771. Brasília(DF), 1989.

Lei n. 8.171 de 17 de Janeiro de 1991. Dispõe sobre a política agrícola. Brasília(DF), 1991.

Lei n. 12.651 de 25 de Maio de 2012. Dispõe sobre a proteção da vegetação nativa.... Brasília(DF), 2012.

CASATTI, L. Alterações no Código Florestal Brasileiro: impactos potenciais sobre a ictiofauna. Biota Neotropica, v. 10, n. 4, p. 31-34, 2010.

DEVELEY, P. F.; PONGILUPPI, T. Impactos potenciais na avifauna decorrentes das alterações propostas para o Código Florestal Brasileiro. Biota Neotropica, v. 10, n. 4, p. 43-45, 2010.

FEARNSIDE, P. M. Código Florestal: o perigo de abrir brechas. Ciência Hoje, v. 28, p. 62-63, 2000.

FREITAS, A. V. L. Impactos potenciais das mudanças propostas no Código Florestal Brasileiro sobre as borboletas. Biota Neotropica, v. 10, n. 4, p. 53-57, 2010.

GALETTI, M. et al. Mudanças no Código Florestal e seu impacto na ecologia e diversidade dos mamíferos no Brasil. Biota Neotropica, v. 10, n. 4, p. 47-52, 2010.

IMPERATRIZ-FONSECA, V. L.; NUNES-SILVA, P. As abelhas, os serviços ecossistêmicos e o Código Florestal Brasileiro. Biota Neotropica, v. 10, n. 4, p. 59-62, 2010.

INCRA. Índices básicos 2005. Disponível em: <http://www.incra.gov.br/estruturafundiaria/regularizacao-fundiaria/indices-cadastrais/file/113-indices-basicos-200512042007>. Acesso em: 20 nov. 2014.

IPEA. Código florestal: Implicações do PL 1876/99 nas áreas de reserva legal. Comunicados do IPEA, n. 96, junho de 2011. Disponível em <www.ipea.gov.br>. Acesso em 20 nov. 2014. 
LAUDARES, S. S. DE A.; OLIVEIRA, A. L. DE; BORGES, L. A. C. Novo código florestal: O que deixa a desejar? Periódico eletrônico do Fórum Ambiental da Alta Paulista, v. 9, n. 5, p. 113-125, 2013.

LEWINSOHN, T. M. A ABECO e o Código Florestal Brasileiro. Natureza \& Conservação, v. 08, n. 01, p. 100-102, 2010.

MAGALHÃES, V. G. O Código Florestal e o aquecimento global. In: LAVRATTI, P.; PRESTES, V. B. (Org.). DIREITO e MUDANÇAS CLIMÁTICAS 4: Reforma do Código Florestal: limites jurídicos. São Paulo: Instituto O Direito por um Planeta Verde, 2010. v. $4.4189 . \quad$ p. 4 Disponível em: $<$ http://www.planetaverde.org/mudancasclimaticas/index.php?ling=por\&cont=publicac oes $>$.

MARQUES, O. A. V. et al. Impactos potenciais das mudanças propostas no Código Florestal Brasileiro sobre os répteis brasileiros. Biota Neotropica, v. 10, n. 4, p. 39-41, 2010.

MARTINELLI, L. et al. A falsa dicotomia entre a preservação da vegetação natural ea produção agropecuária. Biota Neotropica, v. 10, n. 4, p. 323-330, 2010.

MEDEIROS, R.; IRVING, M.; GARAY, I. A proteção da natureza no Brasil: Evolução e conflitos de um modelo em construção. Revista de desenvolvimento econômico, v. 9, p. 83-93, 2004.

METZGER, J. P. Bases biológicas para a "reserva legal." Ciência Hoje, v. 31, n. 183, p. 48-49, 2002.

METZGER, J. P. O Código Florestal tem base científica? Natureza \& Conservação, v. 8 , n. 1, p. 1-5, 2010.

METZGER, J. P. et al. Brazilian law: full speed in reverse? Science, v. 329, p. 276-277, 2010.MONTEIRO FILHO, A. Exposição de motivos do Ministro de Estado dos Negócios da Agricultura. Brasília: [s.n.], 1962. Disponível em: <http://www.camara.gov.br/proposicoesWeb/prop_mostrarintegra;jsessionid=02907890 7911D5E3B413CB37239B7C8E.proposicoesWeb1?codteor $=1202085 \&$ filename $=$ Avuls o+-PL+4494/1962+CM>. Acesso em: 20 nov. 2014.

NEPSTAD, D. et al. Slowing Amazon deforestation through public policy and interventions in beef and soy supply chains. Science, v. 344, n. 6188, p. 1118-1123, 2014.

OLIVEIRA, S. J. DE M.; BACHA, C. J. C. Avaliação do cumprimento da reserva legal no brasil. Revista de economia e agronegócio, v. 1, n. 2, p. 177-204, 2003.

REBELO, A. Parecer do relator deputado federal Aldo Rebelo (PCdoB-SP) ao Projeto de Lei n ${ }^{\circ}$ 1876/99 e apensados (C. Nacional, Ed.) Brasília, 2010.

RIBEIRO, K. T.; FREITAS, L. Impactos potenciais das alterações no Código Florestal sobre a vegetação de campos rupestres e campos de altitude. Biota Neotropica, v. 10, n. 4, p. 239-246, 2010.

SAUER, S.; FRANÇA, F. C. DE. Código Florestal, função social da terra e soberania alimentar. Caderno CRH, v. 25, n. 65, p. 285-387, 2012. 
SENADO. Em discussão!. n. 9, dez de 2011. Disponível em < http://www.senado.gov.br/NOTICIAS/JORNAL/EMDISCUSSAO/upload/201105\%20$\% 20 d e z e m b r o / p d f / e m \% 20 d i s c u s s \% C 3 \%$ A3o!_dezembro_2011_internet.pdf $>$. Acesso em: 20 nov. 2014.

SILVA, J. A. A. et al. O Código Florestal e a Ciência: contribuições para o diálogo. São Paulo: SBPC, Sociedade Brasileira para o Progresso da Ciência ABC, Academia Brasileira de Ciências, 2011. p. 124.

SILVA, S. T. DA et al. CÓDIGO FLORESTAL: em defesa das nossas florestas e do nosso futuro. In: LAVRATTI, P.; PRESTES, V. B. (Org.). DIREITO e MUDANÇAS CLIMÁTICAS 4: Reforma do Código Florestal: limites jurídicos. São Paulo: Instituto O Direito por um Planeta Verde, 2010. v. 4. p. 189. Disponível em: <http://www.planetaverde.org/mudancasclimaticas/index.php?ling=por\&cont=publicac oes $>$.

SIQUEIRA, C. F. A.; NOGUEIRA, J. M. O Novo Código Florestal e A Reserva Legal: do preservacionismo desumano ao conservacionismo politicamente correto. 2004, Cuiabá: SOBER, 2004.

SOARES-FILHO, B. et al. Cracking Brazil's Forest Code. Science, v. 344, n. 6182, p. 363-364, 2014.

SPAROVEK, G. et al. Brazilian agriculture and environmental legislation: status and future challenges. Environmental science \& technology, v. 44, n. 16, p. 6046-53, 2010.

SPAROVEK, G. et al. A revisão do Código Florestal brasileiro. Novos Estudos CEBRAP, n. 89, p. 111-135, 2011.

SPAROVEK, G. et al. The revision of the Brazilian Forest Act: increased deforestation or a historic step towards balancing agricultural development and nature conservation? Environmental Science \& Policy, v. 16, p. 65-72, 2012.

STICKLER, C. M. et al. Defending public interests in private lands: compliance, costs and potential environmental consequences of the Brazilian Forest Code in Mato Grosso. Phil Trans R Soc B, v. 368, p. 13, 2013. Acesso em: 21 nov. 2014.

TOLEDO, L. F. et al. A revisão do Código Florestal Brasileiro: impactos negativos para a conservação dos anfíbios. Biota Neotropica, v. 10, n. 4, p. 35-38, 2010.

TRINDADE, G. Áreas de Preservação Permanente e Reserva Legal: Análise Comparativa entre o atual Código Florestal Federal (Lei ${ }^{0}$ 4.771/65) e o Substitutivo do PL n ${ }^{\circ}$ 1.876/1999 (novo Código Florestal). In: LAVRATTI, P.; PRESTES, V. B. (Org.). DIREITO e MUDANÇAS CLIMÁTICAS 4: Reforma do Código Florestal: limites jurídicos. São Paulo: Instituto O Direito por um Planeta Verde, 2010. v. 4. p. $189 . \quad$ Disponível em: $<$ http://www.planetaverde.org/mudancasclimaticas/index.php?ling=por\&cont=publicac oes $>$.

TUNDISI, J. G.; TUNDISI, T. M. Impactos potenciais das alterações do Código Florestal nos recursos hídricos. Biota Neotropica, v. 10, n. 4, p. 67-75, 2010. 


\section{CAPÍTULO 2}

Efeitos da anistia do Novo Código Florestal nas Reservas

Legais do Cerrado 


\section{Efeitos da anistia do Novo Código Florestal nas Reservas Legais do Cerrado}

\section{INTRODUÇÃO}

Com mais de 2 milhões de $\mathrm{km}^{2}$, o Cerrado é o segundo maior bioma Brasileiro, e é considerada a savana com maior biodiversidade do mundo (EITEN 1972 e 1994, MITTERMEIER et al. 1999, MITTERMEIER et al. 2004). Sua rica biodiversidade vem sendo ameaçada há décadas por altas taxas de desmatamento, em alguns períodos maiores do que na Amazônia (RATTER et al. 1997, KLINK \& MACHADO 2005, PEREIRA \& GAMA 2010, GANEM et al. 2013) e concentrados principalmente em áreas aptas para agropecuária (ROCHA et al. 2011, REDO et al. 2013, FERREIRA et al. 2013). Apesar desta intensa ocupação, o bioma apresenta aproximadamente 40 Mha de áreas que ainda podem ser legalmente desmatadas, concentrados nos estados ao norte do Cerrado (SOARES FILHO et al. 2014), indicando que o desmatamento está longe de ter um fim. Estimativas do Governo Brasileiro apontam que 48,45\% da vegetação nativa do bioma foi suprimida até o ano de 2010, segundo o último dado oficial publicado (MMA 2011). A legislação ambiental tem um papel essencial no controle e na regulação deste desmatamento (NEPSTAD et al. 2002), e no Brasil o Código Florestal (Lei 12.651/2012), lei federal que regula o uso da terra e dos recursos naturais do país, é considerado o principal marco legal ambiental (LEWINSOHN 2010).

O Código Florestal (CF) determina que todo imóvel rural privado deve manter uma área mínima de vegetação nativa em seu interior, que varia de acordo com o bioma no qual se insere. Esta área a ser preservada é denominada de Reserva Legal (RL). Existente desde o primeiro Código Florestal brasileiro (BRASIL 1934), a RL expressa uma característica peculiar da legislação brasileira, que é o compartilhamento da 
obrigação na proteção dos recursos naturais entre o poder público e os proprietários de imóveis privados (MEDEIROS et al. 2004, STICKLER et al. 2013). Sua importância para a preservação é imensa: aproximadamente $24 \%$ da vegetação nativa do Brasil é protegida por RLs (SPAROVECK et al. 2011). No Cerrado, 21\% de seu território é protegido por RLs, ao passo que somente $6,8 \%$ é protegido por Unidades de Conservação (espaços públicos destinados para conservação ambiental) e Terras Indígenas (SPAROVECK et al. 2011).

Em 2012 o Código Florestal foi mudado com a promulgação da Lei 12.651, que ficou conhecida como Novo Código Florestal (NCF). A RL foi alvo de algumas das mais polêmicas alterações perpetradas pelo NCF, principalmente em aspectos relacionados à anistia de sanções ambientais para proprietários que tivessem desmatado sua RL. Para a aplicação da anistia, a lei estabeleceu um tratamento diferente para proprietários com RL desmatada, de acordo com a época do desmatamento e o tamanho da propriedade. Também estabeleceu o conceito, inexistente nas versões anteriores do Código, de "Área Rural Consolidada”, que compreende as áreas em imóveis rurais desmatadas antes da data de 22 de Julho de 2008. Esta data foi escolhida por ser o dia da promulgação do Decreto 6.514, que regulamentou a Lei de Crimes Ambientais (Lei 9.605/98), e substituiu o decreto anterior (Decreto 3.179/99). A partir deste novo decreto, a falta de averbação de RL no cartório passou a ser considerada crime ambiental, apesar do desmatamento dessas áreas já ser tipificado como crime desde o primeiro decreto (de 1999) e a obrigação de se manter RL nas propriedades existir desde 1934. O critério, no mínimo controverso, adotado para a escolha desta data ensejou muitas discussões no Congresso Nacional (SENADO 2011).

A data escolhida (22 de Julho de 2008) foi então estabelecida como um marco temporal para aplicação da anistia das multas ambientais. Todo e qualquer 
desmatamento ocorrido antes desta data pode ser regularizado e ter suas multas suspensas, caso existam, de acordo com o NCF. No entanto a necessidade de recuperar a área desmatada (ou compensa-la mantendo uma área preservada em outra propriedade) depende do tamanho da propriedade. Foi estabelecido um critério baseado no tamanho das propriedades em relação ao módulo fiscal. O módulo fiscal é uma unidade de medida agrária determinada para cada município, expressa em hectares, que pode variar de 5 a 110 hectares em todo o país. O NCF estabelece que propriedades com tamanho igual ou inferior a quatro módulos fiscais não precisam recuperar as áreas de RL desmatadas antes do marco temporal, e estas serão constituídas pela vegetação existente em 22 de Julho de 2008, seja qual for o percentual. Portanto, uma propriedade com área igual ou menor que quatro módulos fiscais, e que tenha desmatado $98 \%$ da propriedade antes da data indicada, terá uma RL de apenas $2 \%$, seja qual for o bioma no qual se insere. Caso o proprietário seja considerado um pequeno produtor, plantios de espécies exóticas podem ser computados para o cálculo. Isto quer dizer que no exemplo anterior, caso estes $2 \%$ de vegetação seja um pomar com espécies exóticas frutíferas, este será considerado sua RL.

Se o imóvel possuir área maior do que quatro módulos fiscais (e tenha desmatado antes da data limite), o NCF prevê duas situações. Se o desmatamento foi realizado de acordo com a legislação vigente à época, sua RL será estabelecida com o percentual definido pela legislação antiga. Um exemplo seria de uma propriedade situada em uma área de Cerrado na Amazônia Legal. Em 1999, a RL estabelecida para esta propriedade era de $20 \%$. Atualmente, a RL exigida é de $35 \%$. O NCF estabelece que, caso a RL desta propriedade tenha sido desmatada em 1999, por exemplo, esta será considerada de acordo com o percentual vigente na época, ou seja, 20\%, mesmo que hoje se exija um percentual maior. Por outro lado, se o desmatamento tiver sido 
realizado em desacordo com a legislação vigente na época, o proprietário terá a multa suspensa mas deverá recuperar ou compensar a RL, que seria manter uma área de vegetação nativa em outra propriedade, através de diversos mecanismos previstos na legislação. Portanto, nota-se que a anistia depende de uma análise temporal do desmatamento realizado na RL de cada propriedade, o que certamente se constituirá em grande desafio para os órgãos ambientais (SPAROVECK et al. 2011).

Segundo o mapeamento realizado pelo IBAMA, através do Projeto de Monitoramento do Desmatamento dos Biomas Brasileiros por Satélite (PMDBBS) até o ano de 2008 já haviam sido desmatados no Cerrado $975.711 \mathrm{~km}^{2}$ de vegetação nativa (MMA 2009), sendo portanto áreas potenciais para enquadramento na anistia proporcionada pelo NCF. Este monitoramento constitui-se em uma excelente ferramenta para determinar, de forma abrangente, quais áreas poderão ter o benefício da anistia no bioma, porém as imagens de satélite utilizadas possuem diferentes datas de passagem, algumas anteriores a 22/07/2008 e outras posteriores (MMA 2009). É necessário que se analise a utilidade do mapeamento na identificação das Áreas Rurais Consolidadas, delimitando as regiões mapeadas que tenham sido analisadas com imagens anteriores a 22 de Julho de 2008, de forma a determinar as áreas aptas a receberem a anistia em uma escala ampla para o bioma.

Uma das justificativas para a flexibilização da legislação ambiental se baseou, de acordo com o relatório que subsidiou o debate no Congresso Nacional, na afirmação de que $90 \%$ dos proprietários rurais não cumpririam o Código Florestal anterior (REBELO 2010). Desta forma, admite-se um impacto negativo para o meio ambiente, por exemplo com a diminuição das áreas protegidas por meio da anistia, em detrimento a um impacto social positivo onde $90 \%$ dos proprietários seriam beneficiados. Existem pelo menos duas grandes questões que emergem desta lógica: os supostos $90 \%$ de proprietários que 
não cumpririam a legislação estariam em desacordo com qual dispositivo especificamente? Este número expressivo de proprietários está localizado uniformemente sobre todos os biomas? Para responder a estas questões deve-se analisálas de forma específica, buscando compreender quais dispositivos da lei não estão sendo cumpridos de forma tão generalizada e aonde isto está ocorrendo. Alguns estudos já apontaram uma distorção no cumprimento de diversos aspectos do CF entre os biomas (SOARES FILHO et al. 2014, SPAROVEK et al. 2010, 2011 e 2012). Em relação à RL, seu déficit no Cerrado (fora da Amazônia Legal) é estimado em 3,4\%, enquanto na Amazônia pode atingir 20\% (SPAROVECK et al. 2010). Assim, a concessão de anistia aos desmatamentos em RLs da Amazônia, onde a exigência é de 80\%, pode ser extremamente benéfica para a regularização dos empreendimentos da região (NEPSTAD et al. 2014). No Cerrado, onde na maior parte a exigência é de $20 \%$, a anistia pode ser inócua. Portanto, o mecanismo de concessão da anistia em áreas de RL deve ser analisado de forma específica para cada bioma, considerando a realidade de cada um.

Para esta análise do mecanismo da anistia, é necessário que se verifique o estado de preservação das RLs. Algumas publicações científicas se propuseram a estimar o passivo ambiental destas áreas. As pesquisas desenvolvidas ou se basearam em dados declaratórios do INCRA (OLIVEIRA \& BACHA 2003) ou utilizam proxys para simular os limites de propriedades rurais, como por exemplo microbacias hidrográficas (SOARES-FILHO et al. 2014) e grades regulares (FERREIRA et al. 2007), ou ainda realizaram a análise por município, considerando como propriedade particular toda área que não pertence à Unidade de Conservação ou Terra Indígena (SPAROVEK et al. 2010). As análises que utilizam limites reais de imóveis rurais normalmente abrangem uma escala pequena, já que utilizam uma malha fundiária local. Um exemplo é o estudo 
de Brancalion \& Rodrigues (2010), que ao analisar propriedades do setor canavieiro de São Paulo, aferiram que um total de $6,4 \%$ da área ocupada pela cultura deveria ser destinada à RL. Feltran-Barbieri \& Kassai (2008) delimitaram 121 propriedades rurais do Cerrado e concluíram que apenas $4 \%$ cumpriam o antigo Código totalmente. Alguns estudos não científicos também se propuseram a elucidar a questão. Em um estudo da ONG Instituto Socioambiental - ISA sobre o sistema de licenciamento do estado do Mato Grosso, foi apurado que em 6.116 propriedades analisadas havia um desmatamento de $1,75 \%$ em áreas de RL (LIMA 2005). Um estudo do Instituto de Pesquisas Aplicadas (IPEA), órgão governamental responsável pela condução de pesquisas que avaliem o impacto de políticas públicas, apontou que $61,7 \%$ da área de RL deveriam ser recuperadas para o cumprimento da legislação antiga (IPEA 2011). Este estudo baseou-se em dados declaratórios do INCRA.

Desta forma, percebe-se que a real estimativa do cumprimento da legislação pelos imóveis rurais brasileiros, pelo menos no que concerne à $\mathrm{RL}$, ainda precisa ser realizada com base em uma malha fundiária que abranja todo o território brasileiro, o que ainda não existe (SPAROVECK et al. 2011). O INCRA tem constituído uma ampla base fundiária através do processo de Certificação de Imóveis Rurais que, apesar de não cobrir todo o território brasileiro, tem uma grande amplitude geográfica, contando atualmente com 62.898 propriedades delimitadas, em um total de 97.981.570,49 hectares (http://certificacao.incra.gov.br/Certifica). No Cerrado, são mais de 36.000 propriedades delimitadas, possibilitando uma ampla análise do cumprimento da RL no bioma.

Com base no exposto, este estudo se propõe a responder as seguintes questões: 1) qual é o efeito potencial da anistia ambiental provocada pela mudança no Código Florestal para o Cerrado? 2) O mapeamento oficial da cobertura vegetal remanescente 
para o Cerrado é adequado para a identificação de áreas rurais consolidadas no bioma? e 3) O cumprimento da legislação ambiental varia conforme o tipo predominante de atividade agropecuária praticada em uma região?

Desta forma, são objetivos deste estudo i) analisar o cumprimento da RL no bioma Cerrado utilizando a base de imóveis certificados pelo INCRA, de forma a apontar uma estimativa da anistia proporcionada pelo NCF e ii) avaliar a utilidade do mapeamento empreendido pelo PMDBBS no ano de 2008 para a identificação das Áreas Rurais Consolidadas previstas no NCF. Adicionalmente, buscou-se também estimar a área de RL que foi desmatada após o marco temporal estabelecido com base nos dados do último mapeamento de áreas desmatadas do Cerrado, que refere-se ao ano de 2010. Por fim, utilizando dados das atividades agropecuárias praticadas no bioma, analisou-se se há alguma relação entre o cumprimento da legislação nas propriedades e o tipo de atividade agropecuária praticada.

\section{MÉTODOS}

Os procedimentos adotados no estudo foram divididos em duas partes: i) Avaliação do PMDBBS como instrumento para determinação de áreas passíveis de anistia de acordo com o NCF e ii) análise do cumprimento do CF especificamente em relação à RL em propriedades rurais certificadas pelo INCRA.

\section{Avaliação do PMDBBS}

As imagens de satélite utilizadas para a identificação das áreas desmatadas pelo projeto foram imagens Landsat, sensor TM, do ano de 2008. A data que ocorreu o desmatamento pode ser determinada através da consulta da data de passagem do satélite (disponível em http://siscom.ibama.gov.br/monitorabiomas/cerrado/index.htm) em cada imagem utilizada para o mapeamento. Desta forma, dividiu-se as imagens em quatro 
grupos: as que possuem data de passagem a) anterior à 22/07, b) posterior a 22/07, c) exatamente em 22/07 e d) as que têm duas datas indicadas, uma antes de 22/07 e outra depois, sendo portanto impossível determinar a data precisa do mapeamento.

Os dados do monitoramento especificam a data de desmatamento das áreas em dois períodos: anteriores a 2002 e entre 2002 e 2008. Assim, todo desmatamento anterior a 2002, em qualquer cena analisada, foi contabilizada como área anistiável. Foram realizadas diferentes análises para cada um dos grupos citados acima para os desmatamentos realizados entre 2002 e 2008 (Tabela 1), conforme descrito abaixo.

Tabela 1. Matriz de decisão para possibilidade de anistia nas áreas de Reserva Legal (RL).

Data de passagem da cena
Situação da RL

Antrópico

Remanescente em 2008 e

Antrópico em 2009

Remanescente em 2008 e

Remanescente em 2009

Antrópico antes de 2002

Antrópico 2002-2008

Remanescente
Passível de anistia?

Sim

Não determinado

Não

\begin{tabular}{ccc}
\hline & Antrópico antes de 2002 & Sim \\
Após 22/07 & Antrópico 2002-2008 & Não determinado \\
& Remanescente & Não \\
\hline Em 22/07 & Antrópico & Sim \\
& Remanescente & Não \\
\hline Data indeterminada & Antrópico antes de 2002 & Sim \\
& Antrópico 2002-2008 & Não determinado \\
& Remanescente em 2008 e \\
& Antrópico em 2009 & Não determinado \\
& $\begin{array}{c}\text { Remanescente em 2008 e } \\
\text { Remanescente em 2009 }\end{array}$ & Não \\
\hline
\end{tabular}


Regiões mapeadas antes de 22/07: as propriedades que apresentaram desmatamento entre 2002 e 2008 na RL nestas regiões foram classificadas como passíveis de anistia. As áreas remanescentes foram analisadas no mapeamento do PMDBBS de 2009. Caso as mesmas continuassem cobertas com vegetação nativa em 2009 foram consideradas não anistiáveis, caso estivessem desmatadas foram consideradas não determinadas (já que foram desmatadas entre uma data não determinada entre 2008 e o ano de 2009).

Regiões mapeadas após 22/07: as áreas desmatadas entre 2002 e 2008 nestas regiões não tiveram a data determinada, pois o desmatamento pode ter ocorrido após 22/07. Áreas com vegetação nativa foram consideradas não passíveis de anistia.

Regiões mapeadas em 22/07: Toda área antropizada foi considerada passível de anistia, já as áreas remanescentes não passíveis.

Regiões com data indeterminada: somente o passivo anterior a 2002 pode ser considerado anistiável e o que estivesse com vegetação em 2009 não anistiável, outras situações foram consideradas indeterminadas.

\section{Análise do cumprimento do CF quanto à RL nas propriedades rurais}

O Cerrado foi delimitado utilizando-se a base vetorial do IBGE (2004). Foi utilizada a base vetorial das propriedades certificadas pelo INCRA (2014). Esta base representa um total de 3,8\% das propriedades rurais do bioma, porém 29,3\% da área coberta por elas, conforme dados do IPEA (2011) sobre os imóveis rurais do Cerrado. Para a correta determinação da RL exigida nas propriedades, foram utilizadas somente as porções das propriedades rurais que se encontram dentro do limite do Cerrado. Sendo assim, se um propriedade localizava-se parte dentro dos limites do bioma e parte nos limites da Amazônia, foi analisada somente a parte pertencente ao Cerrado. Esta 
abordagem decorre do fato de que os órgãos ambientais assim procedem para a determinação da RL em propriedades que ocupam dois biomas, sendo calculada a porcentagem de RL separadamente para cada porção da propriedade dentro de cada um deles. Este procedimento também foi realizado no caso de propriedades que se encontram parte dentro da Amazônia Legal e parte fora, resultando para efeitos desta análise em duas propriedades distintas, cada uma com a porcentagem de RL definida de forma diferente.

A RL das propriedades do bioma Cerrado fora da Amazônia Legal foi considerada como $20 \%$ para todos os estados, exceto para o Piauí, que foi de $30 \%$ (de acordo com a Lei Estadual 5.699/2007). Na Amazônia Legal foi adotado o percentual de $35 \%$. Os remanescentes em cada propriedade foram determinados a partir do mapeamento do PMDBBS do ano de 2008. Visto que o NCF institui a incorporação das Áreas de Preservação Permanente (APP) no cálculo das áreas de RL, este estudo não delimitou as APPs das propriedades, de forma a incorpora-las no cálculo da RL. As APPs são as áreas que tem a função, dentre outras, de preservar os recursos hídricos e garantir a estabilidade geológica (BRASIL 2012), sendo constituídas por matas ciliares, de topo de morro, veredas, áreas declivosas, entre outras. As propriedades foram divididas em dois grupos: maiores do que quatro módulos fiscais e menores do que quatro módulos fiscais, a fim de se analisar as situações específicas previstas pelo NCF para cada classe de tamanho. Para esta classificação foi utilizada a tabela disponível na página do INCRA (http://www.incra.gov.br/estrutura-fundiaria/regularizacaofundiaria/indices-cadastrais/file/113-indices-basicos-2005-204200 7), que apresenta a área dos módulos fiscais por município brasileiro. Dentro de cada propriedade foi determinada a quantidade de vegetação remanescente (caso houvesse) de sua RL, e esta foi classificada nos diferentes grupos apontados na Tabela 1. De posse do mapeamento 
das áreas desmatadas até 2010, analisou-se a área de RL desmatada até este ano e que não é passível de anistia, com o objetivo de quantificar a área total que deverá ser efetivamente recuperada nas propriedades. Os resultados obtidos nesta etapa referem-se, portanto, especificamente às áreas de RL das propriedades, sem abordar as demais áreas das propriedades, passíveis de desmatamento legal. Após estes cálculos, realizou-se uma análise de regressão a fim de verificar a relação entre a porcentagem de imóveis com RL preservada e a quantidade de vegetação remanescente em cada estado. Para isso foi utilizado o software R Core Team (2014), versão 3.1.1.

Para obtenção dos dados relativos às atividades agropecuárias utilizou-se dados do SIDRA IBGE (http://www.sidra.ibge.gov.br), que disponibiliza informações acerca das atividades econômicas por município. Inicialmente utilizou-se somente a tabela com o número de estabelecimentos por atividade agropecuária em 2008 (tabela codificada no SIDRA como 1011). Visto que na imensa maioria dos municípios a atividade de bovinocultura é predominante, o que impediria uma comparação com as demais atividades, optou-se por agregar à análise a tabela 1612 (código do SIDRA), que referese à área plantada de lavoura temporária em 2008. Desta forma, pode-se obter o tipo principal de atividade agropecuária combinada com a lavoura temporária com maior área plantada em cada município. Das 53 combinações resultantes, excluímos as que estivessem presentes em menos de 50 municípios, considerando que estas eram muito pouco representativas. Desta forma, foram utilizadas as quatro principais, que juntas correspondem a $63 \%$ dos municípios e $83 \%$ das propriedades. Visto que os dados do SIDRA são disponibilizados por município, foi calculada uma média do número de propriedades com RL preservada de cada município para a análise proposta. 


\section{RESULTADOS E DISCUSSÃO}

A análise das datas de passagem das imagens utilizadas no PMDBBS de 2008 indicou que das 118 cenas analisadas, 32 (27\%) possuem data posterior a 22/07/2008, $76(65 \%)$ data anterior, 6 cenas (5\%) são exatamente da data de 22/07/2008 e 4 (3\%) possuem duas datas distintas identificadas (Figura 1).

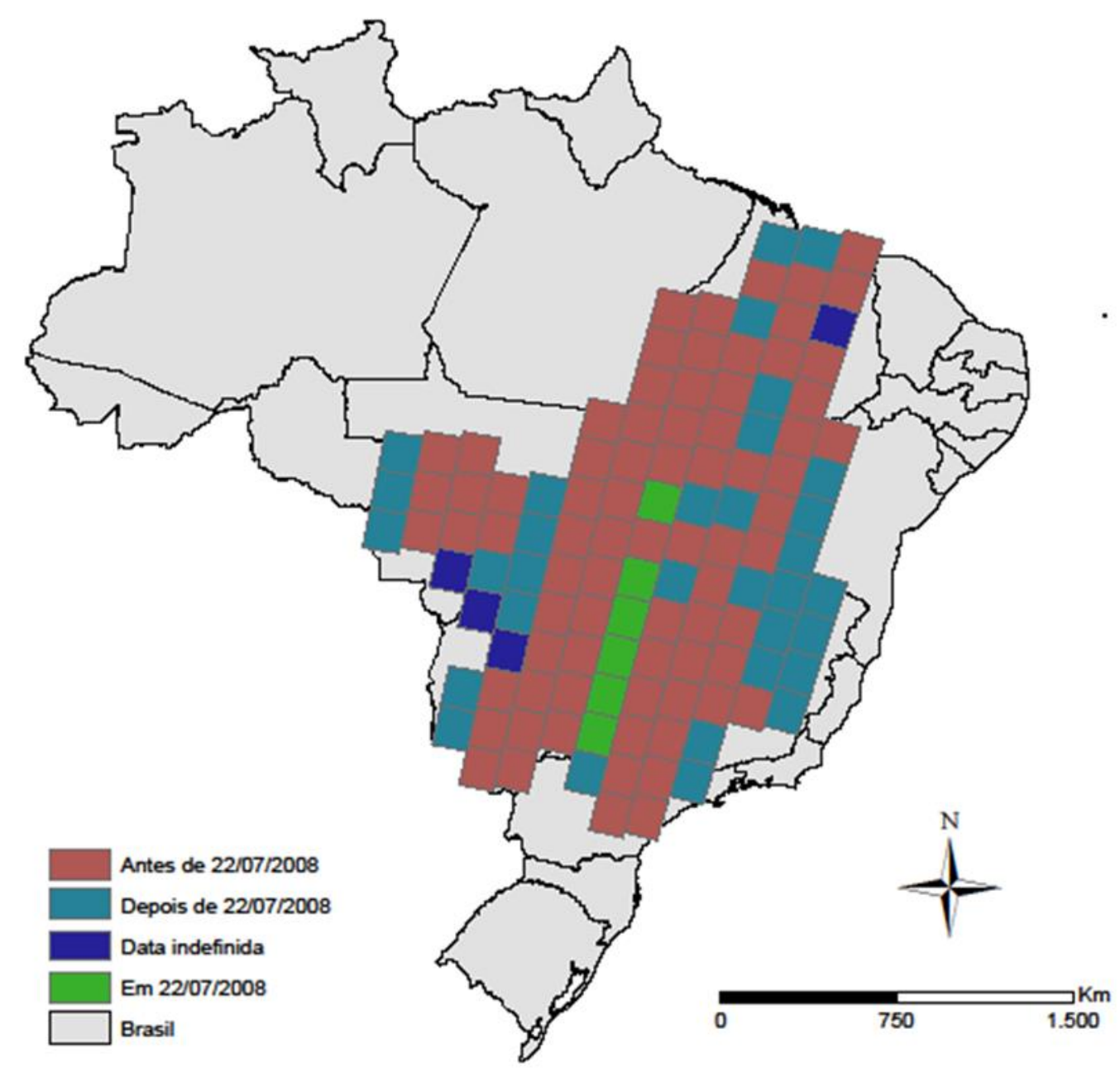

Figura 1. Cenas do satélite LANDSAT utilizadas no Projeto de Monitoramento dos Biomas Brasileiros por Satélite, de acordo com a data da anistia.

Visto que os dados do PMDBBS separam os desmatamento ocorridos antes de 2002 e os ocorridos entre 2002 e 2008, mesmo áreas no interior de cenas com datas de 
passagem após 22/07 (ou sem data identificada) podem ser consideradas anteriores a 22/07, desde que classificadas como anteriores a 2002. Sendo assim, $98 \%$ da área total antropizada no Cerrado $\left(948.428 \mathrm{~km}^{2}\right)$ foram desmatadas até $22 / 07$, constituindo-se em área passível de anistia. Os $2 \%$ restantes $\left(22.945 \mathrm{~km}^{2}\right)$ prescindem outra análise, visto que o desmatamento pode ter ocorrido tanto antes quanto após 22/07/2008. Ressalta-se que existe uma pequena diferença $(0,4 \%)$ entre esta área e a contida no relatório do PMDBBS (MMA 2009), possivelmente devido à pequenas alterações na base vetorial. O resultado demonstra que o PMDBBS é uma boa ferramenta para análise quanto à possibilidade de anistia dos desmatamentos em RL, já que a grande maioria da área antropizada identificada tem a data de ocorrência bem definida, ressaltando-se as situações elencadas no quadro acima.

Em relação à análise do cumprimento do percentual mínimo de RL estabelecido pelo $\mathrm{CF}$, descreveremos o resultado em três partes, uma para propriedades localizadas no bioma Cerrado fora da Amazônia Legal, a qual a RL foi estabelecida em 20\%, outra para as propriedades localizadas no estado do Piauí (RL de 30\%) e mais uma para propriedades localizadas no bioma Cerrado dentro dos limites da Amazônia Legal, nas quais a RL considerada foi de $35 \%$. As 37.275 propriedades analisadas perfazem um total de $511.767 \mathrm{~km}^{2}$ de área, com área média de $13,83 \mathrm{~km}^{2}$ e mediana de $7,03 \mathrm{~km}^{2}$. Destas, 29.943 (80\%) possuem área maior do que quatro módulos fiscais, e 7.332 área menor $(20 \%)$.

\section{Cerrado fora da Amazônia Legal (20\% de RL)}

Foram analisadas 28.526 propriedades localizadas no Cerrado fora da Amazônia Legal, sendo que 22.340 (78\%) possuem área superior a quatro módulos fiscais e 6.186 (22\%) área inferior. Nas propriedades com área superior verificou-se nas RLs um total 
de $13.704 \mathrm{~km}^{2}(21 \%)$ de áreas desmatadas antes de 22/07/2008, $51.083 \mathrm{~km}^{2}(78 \%)$ de áreas remanescentes após a data e 399 km² (1\%) de áreas que foram desmatadas em data não determinada. Desta área remanescente, um total de $517 \mathrm{~km}^{2}$ (1\%) foram desmatados até 2010, constituindo-se em áreas que devem ser recuperadas.

Nas propriedades com menos de quatro módulos fiscais, observou-se que 330 $\mathrm{km}^{2}(49 \%)$ foram desmatados antes de 22/07, $343 \mathrm{~km}^{2}(50 \%)$ se constituem como remanescentes após a data e $7 \mathrm{~km}^{2}(1 \%)$ não tiveram a data de desmate determinada. Um total de $7 \mathrm{~km}^{2}(2 \%)$ da área remanescente foram desmatados até 2010, devendo ser recuperados.

\section{Cerrado no estado do Piauí (30\% de RL)}

Um total de 806 propriedades foram analisadas na porção localizada no bioma Cerrado do estado do Piauí. Destas, 734 possuem área superior e 72 inferior a quatro módulos fiscais. Nos imóveis com área superior a quatro módulos fiscais, somente 154 $\mathrm{km}^{2}(2 \%)$ da área de RL foi desmatada antes do marco temporal. Um total de $7.078 \mathrm{~km}^{2}$ (97\%) permaneciam como remanescente após a data e $78 \mathrm{~km}^{2}(1 \%)$ não tiveram a data de desmate determinada. Verificou-se que até 2010 uma área de $85 \mathrm{~km}^{2}$ (1\%) de RL foram desmatados depois do marco temporal, devendo ser recuperados.

Nas 72 propriedades que apresentaram área inferior a quatro módulos ficais, observou-se que na área de RL destas $6 \mathrm{~km}^{2}$ (23\%) foram desmatados antes de 22/07, $18 \mathrm{~km}^{2}(68 \%)$ permaneciam como remanescentes após esta data e em $2 \mathrm{~km}^{2}(9 \%)$ desmatados não foi possível a determinação da data. Até 2010 um total de $0,06 \mathrm{~km}^{2}$ $(0,3 \%)$ haviam sido desmatados da área remanescente após 22/07, sendo áreas aptas para recuperação. 


\section{Cerrado na Amazônia Legal (35\% de RL)}

Na porção do bioma Cerrado localizada nos limites da Amazônia Legal foram analisados 7.943 imóveis. Deste total, 6.869 possuem área superior a quatro módulos fiscais e 1.074 área inferior. Na área de RL dos imóveis com área superior, 7.103 km² (13\%) foram desmatados antes do marco temporal, $47.071 \mathrm{~km}^{2}$ (86\%) estavam preservados após esta data e $377 \mathrm{~km}^{2}$ (1\%) não tiveram a data de desmatamento definida Um total de $350 \mathrm{~km}^{2}(0,7 \%)$ haviam sido desmatados em área de RL após 22/07/2008 até o ano de 2010, constituindo-se em áreas a serem recuperadas.

Já nos imóveis com área inferior a quatro módulos, verificou-se que 186 km² (32\%) de áreas de RL haviam sido desmatadas antes do marco temporal, enquanto 384 $\mathrm{km}^{2}(67 \%)$ constituíam remanescentes florestais após esta data. Apenas $5 \mathrm{~km}^{2}(1 \%)$ não puderam ter a data de desmatamento definida. As áreas desmatadas em RL de 22/07/2008 a 2010 perfazem um total de $4 \mathrm{~km}^{2}(1 \%)$.

Desta forma, observamos que um total de $522 \mathrm{~km}^{2}(40,7 \%)$ da área analisada de RL em propriedades com menos de quatro módulos fiscais foram desmatadas antes do marco temporal, portanto são áreas onde não há a exigência legal para suas recuperações ou compensações, o que implica em diminuição da área protegida do bioma. Nas propriedades acima de quatro módulos fiscais, $20.961 \mathrm{~km}^{2}(16,5 \%)$ da área analisada de RL foram desmatados antes do marco temporal, portanto poderão ser compensadas ou recuperadas. Uma síntese da quantificação das áreas anistiáveis encontra-se na Tabela 2. 
Tabela 2. Análise das áreas de Reserva Legal (RL) no Cerrado, sem incluir as áreas com data não determinada.

\begin{tabular}{cccccc}
\hline $\begin{array}{c}\text { Porção do } \\
\text { bioma }\end{array}$ & $\begin{array}{c}\text { Reserva } \\
\text { Legal } \\
\text { exigida }\end{array}$ & $\begin{array}{c}\text { Número de } \\
\text { imóveis } \\
\text { analisados }\end{array}$ & $\begin{array}{c}\text { Área } \\
\text { passível de } \\
\text { anistia nas } \\
\text { RLs }\left(\mathbf{k m}^{2}\right)\end{array}$ & $\begin{array}{c}\text { Área não } \\
\text { passível de } \\
\text { anistia nas } \\
\text { RLs }\left(\mathbf{k m}^{2}\right)\end{array}$ & $\begin{array}{c}\text { Área não } \\
\text { passível de } \\
\text { anistia } \\
\text { desmatada } \\
\text { nas RLs de } \\
\mathbf{2 0 0 8 - 2 0 1 0} \\
\left.\mathbf{k m}^{2}\right)\end{array}$ \\
\hline $\begin{array}{c}\text { Cerrado da } \\
\text { Amazônia } \\
\text { Legal }\end{array}$ & $35 \%$ & 7.943 & $7.289(13 \%)$ & $47.455(86 \%)$ & 354 \\
$\begin{array}{c}\text { Cerrado } \\
\text { Estado do } \\
\text { Piauí }\end{array}$ & $20 \%$ & 28.526 & $14.034(21 \%)$ & $51.426(78 \%)$ & 524 \\
\hline
\end{tabular}

A análise quantitativa das áreas que devem ser anistiadas e das áreas que deverão ser recuperadas nos dão uma ideia do tamanho do impacto e dos desafios das novas regras instituídas pelo NCF. Um total de $963 \mathrm{~km}^{2}$ foi desmatado somente nas RLs das propriedades analisadas neste estudo após o MT, sendo os proprietários obrigados, de acordo com o NCF, a recompor a vegetação suprimida. Se extrapolarmos para todo o bioma, considerando que somente uma pequena parte de seus imóveis foi aqui analisada, temos uma dimensão do tamanho do esforço necessário para promover a recuperação ambiental destas áreas. A questão é especialmente importante considerando a falta de conhecimento suficiente sobre os mecanismos de recuperação da vegetação nativa do Cerrado, em comparação a outros biomas (VIEIRA \& SCARIOT 2006).

Uma análise da quantidade de imóveis que cumpriam na íntegra o antigo $\mathrm{CF}$, antes do marco temporal de 22/07/2008 (MT) nos permite avaliar o número de proprietários que deverão ser afetados pelo NCF, tanto sendo beneficiados (através da anistia) ou não (se já tivessem cumprindo o antigo $\mathrm{CF}$ e portanto não receberão qualquer tipo de benefício), como demonstra a Tabela 3. 
Tabela 3. Número de imóveis com áreas de Reserva Legal (RL) preservadas (cumprindo o Código Florestal - CF) em relação ao Marco Temporal de 22/07/2008 (MT).

\begin{tabular}{|c|c|c|c|c|c|}
\hline $\begin{array}{l}\text { Porção do } \\
\text { bioma }\end{array}$ & $\begin{array}{l}\text { Número de } \\
\text { imóveis que } \\
\text { cumpriam o } \\
\text { CF antes do } \\
\text { MT }\end{array}$ & $\begin{array}{l}\text { Número de } \\
\text { imóveis que } \\
\text { desmataram } \\
\text { parcialmente } \\
\text { a RL antes } \\
\text { do MT }\end{array}$ & $\begin{array}{l}\text { Número de } \\
\text { imóveis que } \\
\text { desmataram } \\
\text { totalmente a } \\
\text { RL antes do } \\
\text { MT }\end{array}$ & $\begin{array}{l}\text { Número de } \\
\text { imóveis com } \\
\text { desmate em } \\
\text { RL entre } \\
2008-2009 \\
\text { sem data } \\
\text { determinada }\end{array}$ & Total \\
\hline $\begin{array}{l}\text { Cerrado da } \\
\text { Amazônia }\end{array}$ & $\begin{array}{l}4.886 \\
(61 \%)\end{array}$ & $\begin{array}{l}2.685 \\
(34 \%)\end{array}$ & $\begin{array}{l}244 \\
(3 \%)\end{array}$ & $\begin{array}{l}128 \\
(2 \%)\end{array}$ & 7.943 \\
\hline Cerrado & $\begin{array}{c}12.252 \\
(43 \%)\end{array}$ & $\begin{array}{c}11.352 \\
(40 \%)\end{array}$ & $\begin{array}{l}4.572 \\
(16 \%)\end{array}$ & $\begin{array}{l}350 \\
(1 \%)\end{array}$ & 28.526 \\
\hline Piauí & $\begin{array}{c}671 \\
(83 \%)\end{array}$ & $\begin{array}{c}63 \\
(8 \%)\end{array}$ & $\begin{array}{c}16 \\
(2 \%)\end{array}$ & $\begin{array}{c}56 \\
(7 \%)\end{array}$ & 806 \\
\hline $\begin{array}{c}\text { Bioma } \\
\text { Cerrado }\end{array}$ & $\begin{array}{c}17.809 \\
(48 \%)\end{array}$ & $\begin{array}{c}14.100 \\
(38 \%)\end{array}$ & $\begin{array}{l}4.832 \\
(13 \%)\end{array}$ & $\begin{array}{r}534 \\
(1 \%) \\
\end{array}$ & 37.275 \\
\hline
\end{tabular}

Destes resultados depreende-se que mesmo nas regiões onde as exigências de RL são maiores, como na Amazônia Legal e no Piauí, a maioria dos proprietários dos imóveis analisados cumpriam as exigências de RL do CF na íntegra antes do MT. No Cerrado, um pouco menos do que a metade (43\%) também as cumpriam. Importante ressaltar que na categoria dos imóveis que desmataram parcialmente a RL fazem parte os que possuem qualquer área de desmatamento na RL, desde uma área mínima à sua quase totalidade. Esses resultados permitem afirmar que o conjunto de propriedades analisadas reflete uma realidade bem distinta, pelo menos no que se refere ao cumprimento da RL, da realidade descrita na relatoria do Novo Código Florestal. No documento que apresenta a exposição de motivos para embasar a mudança do Código consta que $90 \%$ das propriedades não cumpriam o antigo CF. Este argumento era um dos principais para defender a mudança na legislação, sob a justificativa de que, visto que a imensa maioria dos proprietários não a cumpriam, a antiga legislação seria praticamente impossível de ser cumprida, e que uma mudança através de sua flexibilização beneficiaria a grande maioria dos produtores. 
Os resultados deste estudo mostram que o cumprimento total da legislação da RL foi observado em quase a metade (48\%) dos 37.275 imóveis analisados, o que demonstra que para este conjunto de propriedades o cumprimento da RL não é algo tão raro. Cabe ressaltar ainda que este número pode ser maior, visto que propriedades que estejam com as RLs corretamente averbadas fora da propriedade foram aqui consideradas não adequadas à lei (ao passo que propriedades que abriguem duas RLs foram consideradas como somente uma). Ainda deve-se atentar para o fato de que propriedades com apenas $1 \%$ de sua RL desmatada são classificadas como não adequadas à lei. A anistia, além da óbvia ampliação da área destinada à atividade agropecuária pode ter ainda outras dimensões. Propriedades inteiramente desmatadas que venham a se regularizar com a anistia irão se valorizar face a propriedades que cumpriram a legislação e, portanto, destinam parte de sua área para conservação de vegetação nativa (IPEA 2011).Isto aponta para um fato preocupante: se somente metade dos proprietários não cumpriram a antiga legislação, e a mudança supostamente iria beneficiar estes proprietários, ao invés de uma política pública que beneficiaria $90 \%$ dos proprietários rurais, podemos ter produzido uma política que beneficia apenas $52 \%$. Com isto, o respaldo do impacto social positivo propalado pelos defensores do NCF diminui sobremaneira.

Consequências negativas advindas de uma flexibilização da legislação ambiental onde $90 \%$ dos proprietários seriam beneficiados poderiam ser minimizadas diante do benefício mais amplo para a sociedade. O que o conjunto de dados deste estudo demonstra é que tais consequências podem ter beneficiado um número bem menor de proprietários do que se imaginava, pelo menos em relação à RL. Para entendermos melhor o alcance do benefício promovido pela anistia, também devemos analisar sua distribuição no bioma Cerrado. Onde se localizam as propriedades que terão os 
desmatamentos realizados em suas RLs anistiados? A distribuição das propriedades desmatadas não apresenta uma distribuição espacial uniforme, havendo uma maior concentração de propriedades com a RL desmatada no centro-sul do bioma (Figura 2).

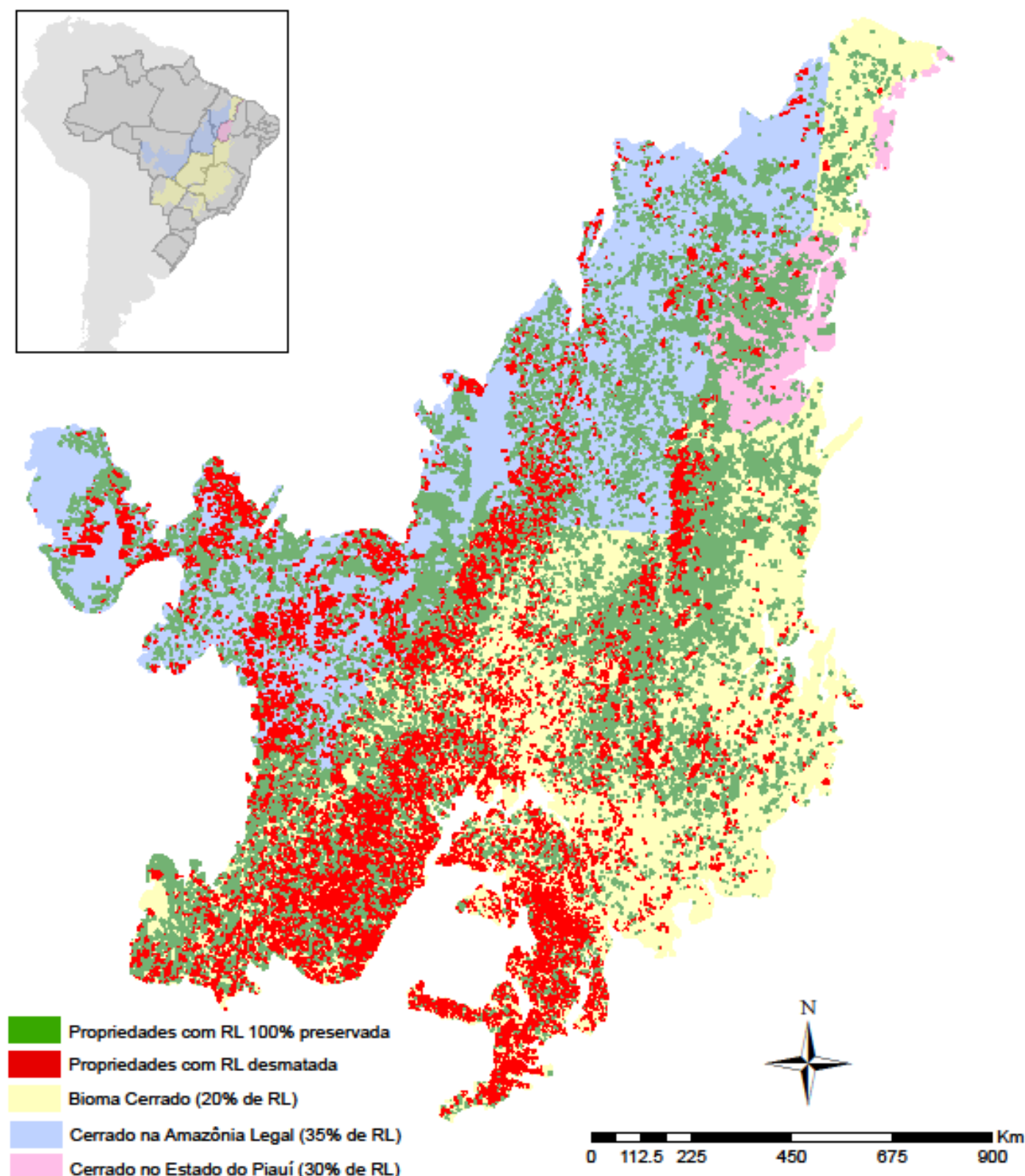

Figura 2. Distribuição das propriedades com Reserva Legal preservada e com algum desmate no bioma Cerrado

A Tabela 4 resume a distribuição das propriedades do bioma de acordo com o grau de desmatamento da RL e a UF na qual se localiza, por ordem de preservação. Para 
uma análise somente das propriedades nas quais se tem certeza da data desmatamento de sua RL, esta tabela não inclui as propriedades com desmatamento sem data definida.

Tabela 4. Número de imóveis com Reserva Legais (RL) em diferentes condições por Unidade de Federação, em relação ao Marco Temporal de 22/07/2008 (MT). Esta lista não inclui as propriedades com desmatamento da RL sem data definida.

\begin{tabular}{|cccccc}
\hline UF & $\begin{array}{c}\text { RL 100\% } \\
\text { preservada } \\
\text { antes do } \\
\text { MT }\end{array}$ & $\begin{array}{c}\text { RL 100\% } \\
\text { desmatada } \\
\text { antes do MT }\end{array}$ & $\begin{array}{c}\text { RL com algum } \\
\text { desmate antes } \\
\text { do MT }\end{array}$ & $\begin{array}{c}\text { Total } \\
\text { de } \\
\text { imóveis }\end{array}$ & $\begin{array}{c}\text { Remanescent } \\
\text { e de } \\
\text { vegetação } \\
\text { nativa em } \\
\mathbf{2 0 0 8} *\end{array}$ \\
\hline PA & $3(100 \%)$ & 0 & 0 & 3 & $\begin{array}{c}\text { Sem dado } \\
\text { PI }\end{array}$ \\
\hline $671(90 \%)$ & $16(2 \%)$ & $63(8 \%)$ & 750 & $84 \%$ \\
\hline MA & $1.129(83 \%)$ & $28(2 \%)$ & $198(15 \%)$ & 1.355 & $77 \%$ \\
\hline TO & $2.163(75 \%)$ & $33(1 \%)$ & $706(24 \%)$ & 2.902 & $73 \%$ \\
\hline BA & $1.725(71 \%)$ & $309(13 \%)$ & $404(16 \%)$ & 2.438 & $63 \%$ \\
\hline MG & $2.262(53 \%)$ & $445(10 \%)$ & $1.572(37 \%)$ & 4.279 & $43 \%$ \\
\hline GO & $3.956(51 \%)$ & $581(7 \%)$ & $3.264(42 \%)$ & 7.801 & $34 \%$ \\
\hline MT & $1.855(48 \%)$ & $183(5 \%)$ & $1.791(47 \%)$ & 3.829 & $57 \%$ \\
\hline PR & $38(42 \%)$ & $20(22 \%)$ & $33(36 \%)$ & 91 & $30 \%$ \\
\hline MS & $2.993(41 \%)$ & $1.067(14 \%)$ & $3.289(45 \%)$ & 7.349 & $24 \%$ \\
\hline DF & $91(28 \%)$ & $180(55 \%)$ & $56(17 \%)$ & 327 & $29 \%$ \\
\hline SP & $923(16 \%)$ & $1.970(35 \%)$ & $2.724(49 \%)$ & 5.617 & $9 \%$ \\
\hline Média & $58 \%$ & $14 \%$ & $28 \%$ & 36.741 & $48 \%$ \\
\hline (\%) & & & & & \\
\hline adaptado do PMDBBS (MMA 2009$)$ & & & & \\
\hline
\end{tabular}

Ressalvando-se o fato do estado do Pará apresentar um baixo número de propriedades (somente três) devido à pequena porção do bioma Cerrado que se localiza naquele estado, o Piauí apresenta a maior proporção de propriedades cumprindo o CF. Ressalta-se que naquele estado a exigência de RL (30\%) é ainda maior que na maioria dos estados do bioma (20\%). O Maranhão e o Tocantins também apresentaram altos índices de cumprimento da RL. Estes três estados têm também a maior área de remanescentes nativos do bioma Cerrado (MMA 2009, SANO et al. 2010).

Já São Paulo apresentou um número expressivamente baixo de propriedades com a RL mínima exigida em comparação aos demais, sendo verificada esta condição em somente $16 \%$ dos imóveis. Essa situação reflete a condição de unidade da federação 
com a menor cobertura florestal do bioma Cerrado (MMA 2009, SANO et al. 2010), possivelmente reflexo de sua ocupação mais antiga no bioma (SANO et al. 2010). Foi também observado no Distrito Federal um baixo índice de cumprimento da RL, porém o pequeno número de propriedades analisadas (327) em comparação aos demais pode ter influenciado este resultado.

Apesar do Mato Grosso e da Bahia serem apontados com as maiores taxas de desmatamento no período 2002-2009 (ROCHA et al. 2011), estes não apresentaram neste estudo uma taxa baixa de cumprimento do CF (48 e $71 \%$ respectivamente), sendo que na Bahia a maioria dos imóveis cumpriam a legislação. Isto pode refletir, em uma visão mais otimista, uma ocupação recente com maior respeito à legislação, ou mesmo que o desmatamento apontado ocorreu fora das propriedades analisadas.

Estes fatores podem ser observados em uma análise de regressão entre a porcentagem do número de imóveis com a RL preservada e a cobertura vegetal remanescente em cada UF, em 2008. A alta relação positiva verificada entre estas duas variáveis, com $\mathrm{r}^{2} 0,88(\mathrm{p}<0,001, \mathrm{gl}=10)$ era esperada, porém alguns estados apresentaram um interessante desajuste da linha de regressão, sendo que MT, DF e GO apresentaram os maiores resíduos (-14.5, -9.7 e 8.2 respectivamente). Ressalvando o DF, cujo baixo número de propriedades analisadas impede uma comparação com os demais, observamos dois cenários distintos entre GO e MT. Ao passo de que a maior porcentagem de propriedades com RL preservada do Goiás (51\%) contrasta com sua baixa porcentagem de remanescente da vegetação nativa (34\%), no MT ocorre justamente o contrário (48\% de propriedades com RL preservada e 57\% de vegetação remanescente). Alguns dos possíveis motivos para estes resultados podem ser reflexo de uma ocupação menos predatória no Goiás, a exigência de uma RL maior no Mato Grosso (visto que se localiza na Amazônia Legal), ou ainda a existência de extensas 
Terras Indígenas neste último, que se constituem em grandes maciços de vegetação nativa preservada, inflando o dado de vegetação remanescente. Obviamente o conjunto de propriedades analisadas também pode influenciar neste resultado, visto que pode haver uma realidade distinta nas demais propriedades não analisadas das UFs, o que só poderia ser verificado de forma inequívoca a partir de uma malha fundiária completa.

A análise dos imóveis com RL desmatada por UF também aponta uma preocupante distorção regional da aplicação do benefício da anistia. Este resultado corrobora o estudo apontado em Sparoveck et al. (2010), que já demonstrou uma grande disparidade no déficit de RL dentro dos diferentes biomas. Assim como discutido acima em relação à abrangência da anistia para o total de imóveis do Cerrado, um benefício oriundo de uma mudança na legislação que beneficia de forma seletiva alguns estados em detrimento a outros também deve ter seu impacto social questionado. O estado de São Paulo parece ser o principal beneficiário da anistia, visto que a maior parte (84\%) de suas propriedades poderão ter esse benefício. Soma-se isto ao fato de que a maioria da vegetação nativa do Cerrado deste estado encontra-se em Áreas de Preservação Permanente (SANO et al. 2010), indicando que a incorporação destas áreas na RL já beneficiaria a maioria dos proprietários. Já em Estados como Piauí, Maranhão e Tocantins, por outro lado, somente uma minoria dos proprietários analisados serão beneficiados com a nova legislação. Esta distorção no cumprimento da legislação entre os estados integrantes do Cerrado aponta a necessidade de se realizar esta investigação para cada bioma, pois estes também podem apresentar o mesmo cenário. Apesar da anistia ser considerada benéfica para a Amazônia (NEPSTAD et al. 2014), seus aspectos positivos em áreas desmatadas de RL do bioma Cerrado podem ser bem menores do que se esperava em alguns estados. 
A atividade agropecuária certamente é o principal vetor do desmatamento no Cerrado (RATTER et al. 1997, KLINK \& MACHADO 2005, FERREIRA et al. 2013) e os diferentes tipos de atividades podem causar níveis de impacto diferentes sobre a paisagem (SPAROVECK et al. 2010). Por exemplo, em Goiás, paisagens dominadas por pastagens tendem a ser menos fragmentadas e possuem maior cobertura florestal do que as dominadas por atividades agrícolas (CARVALHO et al. 2009). Portanto, deve-se esperar que os diferentes tipos de atividades agropecuárias praticada nas propriedades também apresentem diferentes graus de cumprimento da legislação. Esta análise é importante para se entender quais setores do agronegócio mais contribuem para o quadro de inadequabilidade à legislação. Obteve-se para isto a média de número de propriedades que possuem a RL preservada dos municípios com as principais atividades agrícolas do bioma (Tabela 5).

Tabela 5. Principal atividade agropecuária seguida da lavoura temporária com maior área plantada nos municípios e a média da porcentagem de propriedades que preservam a Reserva Legal (RL).

\begin{tabular}{lccc}
\hline $\begin{array}{c}\text { Principal atividade } \\
\text { agropecuária e lavoura } \\
\text { temporária com maior }\end{array}$ & $\begin{array}{c}\text { Média de preservação } \\
\text { da RL }\end{array}$ & $\begin{array}{c}\text { Número de } \\
\text { municípios }\end{array}$ & $\begin{array}{c}\text { Número de } \\
\text { propriedades }\end{array}$ \\
\hline $\begin{array}{l}\text { Bovinocultura e arroz } \\
\text { Bovinocultura e soja }\end{array}$ & $75 \%^{\text {a }}$ & 68 & 1.668 \\
Bovinocultura e milho & $54 \%^{\mathrm{b}}$ & 262 & 18.063 \\
Bovinocultura e cana & $53 \%^{\mathrm{b}}$ & 357 & 5.847 \\
\hline *Letras ao lado das porcentagens indicam as médias diferentes entre si $(\mathrm{p}<0,001)$ &
\end{tabular}

*Letras ao lado das porcentagens indicam as médias diferentes entre $\mathrm{si}(\mathrm{p}<0,001)$.

A atividade de rizicultura apresentou a maior média, com $75 \%$ das propriedades analisadas com a RL inteiramente preservada. A atividade se concentra quase exclusivamente no Tocantins e Norte do Maranhão, UFs que concentraram altos índices de preservação de RL, o que pode explicar este resultado. Além disso, grande parte da rizicultura no Maranhão ocupa áreas de inundação temporária, que são áreas de distribuição restrita, tornando-se uma atividade que gera pouco desmatamento (FILHO 
\& JUNIOR 2009). As atividades de soja e milho obtiveram médias semelhantes de propriedades preservando a RL, provavelmente por serem culturas com manejo semelhante e que muitas vezes são plantadas alternadamente na mesma propriedade, dependendo do preço que atingem no ano. A cultura da cana obteve a menor média, possivelmente devido à sua ocupação mais antiga, e de sua maior parte se concentrar em São Paulo. Porém, não deve-se atribuir o estado de baixa preservação exclusivamente a esta cultura, pois uma recente expansão desta ocorreu em áreas já desmatadas, principalmente pela atividade de pastagem (SPAROVECK et al. 2008).

\section{CONCLUSÕES}

A anistia proporcionada em propriedades com área inferior a quatro módulos fiscais vai diminuir a área de Reserva Legal do Cerrado.

Os resultados apresentados demonstram que dois aspectos são especialmente preocupantes em relação à anistia do desmatamento de RLs no Cerrado: somente pouco mais da metade dos imóveis analisados irá receber o benefício da anistia, e a distribuição deste no bioma Cerrado possui uma grande distorção entre as Unidades de Federação.

Também apontam que há uma necessidade de investigar individualmente os diversos mecanismos de flexibilização ambiental que geram diretamente uma diminuição das áreas particulares protegidas advindos do NCF. O caso aqui investigado demonstra que a anistia na RL, além de possuir uma grande desigualdade regional, favorece somente um pouco mais da metade dos imóveis analisados. Há a necessidade de futuras investigações específicas dos demais mecanismos a fim de determinar se todos são realmente efetivos em se promover uma maior adequação à legislação ambiental. 


\section{REFERÊNCIAS BIBLIOGRÁFICAS}

BRANCALION, P. H. S.; RODRIGUES, R. R. Implicações do cumprimento do Código Florestal vigente na redução de áreas agrícolas: um estudo de caso da produção canavieira no Estado de São Paulo. Biota Neotropica, v. 10, n. 4, p. 63-66, 2010.

BRASIL. Decreto n. 23.793 de 23 de Janeiro de 1934. Institui o Código Florestal Brasileiro. Rio de Janeiro (RJ), 1934.

Lei n. 12.651 de 25 de Maio de 2012. Dispõe sobre a proteção da vegetação nativa.... Brasília(DF), 2012.

CARVALHO, F. M. V; JÚNIOR, P. D. M.; FERREIRA, L. G. The Cerrado into-pieces: Habitat fragmentation as a function of landscape use in the savannas of central Brazil. Biological Conservation, v. 142, n. 7, p. 1392-1403, 2009.

EITEN, G. The Cerrado vegetation of Brazil. The Botanical Review, v. 38, n. 2, p. 201-341, 1972.

EITEN, G. Vegetação do Cerrado. In: PINTO, M. N. (Org.). Cerrado: caracterização, ocupação e perspectivas. Brasília: Editora da UNB, 1994. p. 17-73.

FELTRAN-BARBIERI, R.; KASSAI, J. R. Passivo ambiental das reservas legais inexistentes no Cerrado. In: IX Simpósio Nacional do Cerrado. EMBRAPA. Brasília/DF 2008.

FERREIRA, M. E. et al. Base de dados territoriais necessárias à análise de um sistema de Reserva Legal extra-propriedade no estado de Goiás. Boletim Goiano de Geografia, v. 27, n. 1, p. 28-46, 2007.

FERREIRA, M. E. et al. Considerations about the land use and conversion trends in the savanna environments of Central Brazil under a geomorphological perspective. Journal of Land Use Science, 2013.

FILHO, M. S. F.; JÚNIOR, A. S. DE L. F. A cultura do arroz em sistema de vazante na baixada maranhense, periferia do sudeste da Amazônia. Pesquisa Agropecuária Tropical, v. 39, n. 2, p. 82-91, 2009.

GANEM, R. S.; DRUMMOND, J. A.; FRANCO, J. L. D. A. Conservation polices and control of habitat fragmentation in the brazilian Cerrado biome. Ambiente \& Sociedade, v. 16, n. 3, p. 99-118, 2013.

IBGE. Instituto Brasileiro de Geografia e Estatística. Mapa de Biomas do Brasil. Escala 1:5.000.000. IBGE, 2004.

INCRA. Imóveis Certificados - Lei 10267/2001 - Privado. Disponível em < http://acervofundiario.incra.gov.br/i3geo/interface/incra.html>. Acesso em 20 fev. 2014.

IPEA. Código florestal: Implicações do PL 1876/99 nas áreas de reserva legal. Comunicados do IPEA, n. 96, junho de 2011. Disponível em <www.ipea.gov.br>. Acesso em 20 nov. 2014.

KLINK, C. A.; MACHADO, R. B. A conservação do Cerrado brasileiro. Megadiversidade, v. 1, n. 1, p. 147-155, 2005.

LEWINSOHN, T. M. A ABECO e o Código Florestal Brasileiro. Natureza \& Conservação, v. 08, n. 01, p. 100-102, 2010. 
LIMA, A. Mato Grosso, Amazônia (i)Legal Desmatamentos de florestas em propriedades rurais integradas ao Sistema de Licenciamento Ambiental Rural entre 2001 e 2004. Instituto Socioambiental. Brasília. 2005

MEDEIROS, R.; IRVING, M.; GARAY, I. A proteção da natureza no Brasil: Evolução e conflitos de um modelo em construção. Revista de desenvolvimento econômico, v. 9, p. 83-93, 2004.

MITTERMEIER, R.A., MEYERS, N., ROBLES GIL, P. \& MITTERMEIER, C.G. Hotspots Earth's biologically richest and most endangered terrestrial ecoregions. CEMEX/Conservation International, The University of Chicago Press, Chicago. 1999.

MITTERMEIER, R.A., ROBLES GIL, P., HOFFMANN, M., PILGRIM, J., BROOKS, T., MITTERMEIER, C.G., LAMOREUX, J. \& FONSECA, G.A.B. (2004) Hotspots Revisited. CEMEX, Mexico City.

MMA. Relatório técnico de monitoramento do desmatamento no bioma Cerrado, 2002 a 2008: Dados revisados. Ministério do Meio Ambiente. Brasília: Centro de informação, documentação ambiental e editoração Luís Eduardo Magalhães: 69 p. 2009.

MMA. Monitoramento do desmatamento nos biomas brasileiros por satélite. Ministério do Meio Ambiente. Brasília: Centro de informação, documentação ambiental e editoração Luís Eduardo Magalhães: 65 p. 2011.

NEPSTAD, D. et al. Frontier governance in Amazonia. Science, v. 295, n. 5555, p. 629-631, 2002.

NEPSTAD, D. et al. Slowing Amazon deforestation through public policy and interventions in beef and soy supply chains. Science, v. 344, n. 6188, p. 1118-1123, 2014.

OLIVEIRA, S. J. DE M.; BACHA, C. J. C. Avaliação do cumprimento da reserva legal no Brasil. Revista de economia e agronegócio, v. 1, n. 2, p. 177-204, 2003.

PEREIRA, A. C.; GAMA, V. F. Anthropization on the Cerrado biome in the Brazilian UruçuíUna Ecological Station estimated from orbital images. Brazilian Journal of Biology, v. 70, n. 4, p. 969-976, 2010.

R CORE TEAM. $R$ : A language and environment for statistical computing. Vienna, Austria: $\mathrm{R}$ Foundation for Statistical Computing. Disponível em: <http://www.r-project.org/>. 2014

RATTER, J. A.; RIBEIRO, J. F.; BRIDGEWATER, S. The Brazilian Cerrado Vegetation and Threats to its Biodiversity. Annals of Botany, v. 80, p. 223-230, 1997.

REBELO, A. Parecer do relator deputado federal Aldo Rebelo (PCdoB-SP) ao Projeto de Lei ${ }^{\circ}$ 1876/99 e apensados. Congresso Nacional. Brasília: 270 p. 2010.

REDO, D.; AIDEA, T. M.; CLARK, M. L. Vegetation change in Brazil's dryland ecoregions and the relationship to crop production and environmental factors: Cerrado, Caatinga, and Mato Grosso, 2001-2009. Journal of Land Use Science, v. 8, n. 2, p. 123-153, 2013.

ROCHA, G. F. et al. Detecção de desmatamentos no bioma Cerrado entre 2002 e 2009: Padrões, tendências e impactos. Revista Brasileira de Cartografia, v. 03, n. 63, p. 341-349, 2011.

SANO, E. E. et al. Land cover mapping of the tropical savanna region in Brazil. Environ Monit Assess, v. 166, n. 1-4, p. 113-124, 2010. 
SENADO. Em discussão!. n. 9, dez de 2011. Disponível em < http://www.senado.gov.br/NOTICIAS/JORNAL/EMDISCUSSAO/upload/201105\%20-

$\% 20 d e z e m b r o / p d f / e m \% 20 d i s c u s s \% C 3 \%$ A3o!_dezembro_2011_internet.pdf $>$. Acesso em: 20 nov. 2014.

SOARES-FILHO, B. et al. Cracking Brazil's Forest Code. Science, v. 344, n. 6182, p. $363-$ 364, 2014.

SPAROVEK, G. et al. Environmental, land-use and economic implications of Brazilian sugarcane expansion 1996-2006. Mitigation and Adaptation Strategies for Global Change, v. 14 , n. 3, p. $285-298,2008$

SPAROVEK, G. et al. Brazilian agriculture and environmental legislation: status and future challenges. Environmental science \& technology, v. 44, n. 16, p. 6046-53, 2010.

SPAROVEK, G. et al. A revisão do Código Florestal brasileiro. Novos Estudos - CEBRAP, n. 89, p. 111-135, 2011.

SPAROVEK, G. et al. The revision of the Brazilian Forest Act: increased deforestation or a historic step towards balancing agricultural development and nature conservation? Environmental Science \& Policy, v. 16, p. 65-72, 2012.

STICKLER, C. M. et al. Defending public interests in private lands: compliance, costs and potential environmental consequences of the Brazilian Forest Code in Mato Grosso. Phil Trans $R$ Soc B, v. 368, p. 13, 2013.

VIEIRA, D. L. M.; SCARIOT, A. Principles of natural regeneration of tropical dry forests for restoration. Restoration Ecology, v. 14, n. 1, p. 11-20, 2006. 


\section{CAPÍTULO 3}

Mudanças na compensação de Reserva Legal no Cerrado: resolvendo um problema para criar outro? 


\section{Mudanças na compensação de Reserva Legal no Cerrado: resolvendo um problema para criar outro?}

\section{INTRODUÇÃO}

O Código Florestal brasileiro é a principal legislação ambiental do país (LEWINSOHN 2010, SPAROVECK et al. 2012). Um dos seus elementos básicos é a Reserva Legal (RL), um percentual mínimo que todo proprietário deve destinar em seu imóvel rural para a conservação da vegetação nativa. A RL existe desde o primeiro Código Florestal de 1934, e segundo a legislação, apenas seu uso sustentável é permitido. Até o final da década de 90, os proprietários que tivessem desmatado toda a propriedade, sem deixar o percentual mínimo, deveriam revegetar as áreas a fim de compor suas RLs. Porém, com o crescente número de proprietários sem RL, o governo decidiu flexibilizar a legislação naquela época (BONNET et al. 2006).

Em 1998 foi editada uma Medida Provisória (MP 1.605/98) permitindo que ao invés de recuperar a área requerida em sua propriedade, o proprietário poderia manter uma área de igual tamanho em outra propriedade, por meio do mecanismo de compensação. A compensação de RL pode ser entendida como um mecanismo de ‘transferência dos direitos de desenvolvimento' - TDR (do inglês Transferable development rights) (CHOMITZ 2004, BONNET et al. 2006), onde uma restrição imposta a uma propriedade pode ser exercida em outro local. No caso, o proprietário que abriga uma RL de outro proprietário não perde o direito de explorar a sua propriedade, só não pode exercê-lo em sua propriedade, podendo vender este direito para que outra propriedade explore além do permitido, o que torna economicamente viável a manutenção da vegetação nativa (PANAYOTOU 1994). 
Quatro critérios foram definidos na época para a escolha da área receptora da RL: (i) estar localizada na mesma microbacia hidrográfica, (ii) pertencer ao mesmo ecossistema, (iii) ter igual importância ecológica e (iv) possuir a mesma extensão da área a ser compensada. Além disso, foi estabelecido um marco temporal no qual somente propriedades com RL desmatada antes de 14 de Dezembro de 1998 poderiam realizar a compensação (BRASIL 1965). Estas regras perduraram até 2012, quando o governo, pressionado pelo setor do agronegócio, editou o Novo Código Florestal (NCF) (NEPSTAD et al. 2014). A partir da nova lei, novos critérios foram definidos para permitir a compensação extra-propriedade da RL: a) a propriedade deveria pertencer ao mesmo bioma, b) deveria localizar-se em área prioritária para conservação se fora da unidade da federação em questão, c) deveria ter a mesma extensão, e d) a propriedade deveria estar na condição inadimplente até 22 de Julho de 2008 (Tabela 1).

Tabela 1. Mudanças nas regras para compensação de Reserva Legal (RL).

\begin{tabular}{|c|c|} 
Versões do Código & $\begin{array}{c}\text { Data limite para } \\
\text { o desmatamento } \\
\text { da RL }\end{array}$ \\
\hline
\end{tabular}

\begin{tabular}{cll} 
& \multicolumn{2}{c}{ propriedade } \\
\hline \multirow{2}{*}{$\begin{array}{cl}\text { Antigo Código Florestal } \\
\text { Lei 4.771/65 }\end{array}$} & Equivalente em importância \\
& & ecológica \\
& Equivalente em extensão \\
& Pertencer ao mesmo ecossistema \\
& Localizada na mesma microbacia \\
\hline \multirow{2}{*}{ Novo Código Florestal } & $22 / 07 / 2008$ & Equivalente em extensão \\
Lei 12.651/12 & & Localizada no mesmo bioma \\
& & Se fora do Estado, localizada em \\
& áreas prioritárias \\
\hline
\end{tabular}

Critérios para escolha da área onde será alocada a RL da propriedade 
a) Aumento da data limite do desmatamento de RL: antes, somente proprietários com RL desmatada até 14/12/1998 poderiam compensar a RL, agora admitem-se desmatamentos realizados até 22/07/2008.

b) Eliminação dos dois critérios que garantiam similaridade ecológica entre as áreas, que eram pertencer ao mesmo ecossistema e serem equivalentes em importância ecológica. Novas compensações não precisam atender a estes critérios.

c) Aumento da escala espacial admitida para compensação: antes as propriedades deveriam localizar-se na mesma microbacia hidrográfica, agora podem localizar-se no mesmo bioma.

Estas três mudanças promoveram uma flexibilização notável nas regras instituídas para compensação. $\mathrm{O}$ aumento da data limite beneficia todos os proprietários que ignoraram a lei e continuaram desmatando a RL após 1998, e certamente frustra quem a cumpriu no período, além de reforçar uma sensação de impunidade em relação à legislação (SOARES-FILHO et al. 2014). A eliminação dos dois critérios ecológicos permite que áreas completamente distintas do ponto de vista ecológico possam ser utilizadas para compensação, podendo levar à extinção de ecossistemas mais ameaçados em detrimento da preservação de outros. Por outro lado, o aumento da escala espacial poderá concentrar as RLs em locais com baixa pressão de desmatamento, ao invés de proteger justamente os locais mais ameaçados. Com isto, a mudança acabou se tornando uma solução mais barata para os proprietários rurais, mas menos efetiva na conservação das áreas (SPAROVECK et al. 2012). Com a nova lei, um proprietário que possui uma área de Floresta Estacional Semidecídua em São Paulo poderia desmatar completamente sua propriedade e manter sua RL em uma área de floresta em Pernambuco, por exemplo (SILVA et al. 2011). 
Visto que a função das áreas de Reserva Legal, conforme estabelecido pela lei, deve ser a de promover a conservação da biodiversidade, os mecanismos envolvidos na escolha das áreas devem respeitar primariamente esta condição (METZGER 2010). Portanto, a mudança de regra para a compensação, explicitada acima, em especial a mudança da escala espacial admissível, deve ser objeto de análise quanto à sua manutenção da função da Reserva Legal, qual seja, a de promover a conservação da biodiversidade.

Para promover a conservação da biodiversidade, a questão chave na compensação de Reserva Legal é determinar se a área onde esta será abrigada tem biodiversidade similar à da propriedade original, de forma a não haver perda da representatividade da diversidade biológica no processo de compensação. Estudos sobre biodiversidade apontam que esta varia de acordo com as diversas condições ambientais locais, como latitude, longitude, altitude e isolamento (e.g. GASTON 2000), e que os ambientes ocorrem em mosaicos, formando diferentes habitats (HUTCHINSON 1959). A diversidade pode ser de forma geral distinta em três níveis: a diversidade alfa (diversidade local), beta (entre locais) e gama (regional), segundo a definição clássica de Whittaker (1960). O estudo da diversidade beta, ou diversidade composicional, é muito importante para a conservação, devido à sua influência na diversidade em escalas maiores (CONDIT et al. 2002). Se duas áreas são idênticas, a diversidade beta deve ser zero; quanto menos similares, maior será a diversidade beta. Portanto, as áreas de compensação de Reserva Legal devem ter baixa diversidade beta em relação às áreas originais.

Um dos biomas que pode apresentar perda de biodiversidade com a nova regra de compensação é o Cerrado, visto que este bioma apresenta alta diversidade beta para diversos grupos, em especial as plantas (RATTER et al. 1997; FELFILI et al. 2004; 
CARVALHO \& FELFILI 2011). De acordo com Eiten (1994), em um único hectare podem ser encontradas até 450 espécies de plantas, o que torna o Cerrado a savana tropical mais diversificada do mundo. Ratter et al. (2003), em um extenso estudo em 376 áreas no Cerrado, observaram esta variação na riqueza de plantas de porte arbóreo dentro do bioma. Utilizando análises multivariadas, o estudo identificou seis grandes grupos de acordo com a similaridade florística, demonstrando a grande diversidade entre locais do bioma. O mesmo estudo apontou que, na área central do Cerrado, das 914 espécies levantadas, 300 ocorreram em menos de 2,5\% do total de locais estudados e 309 (33\%) ocorreram em apenas um sítio, evidenciando uma grande especificidade local das espécies. Em outro estudo em 15 áreas localizadas em três regiões fisiográficas distintas dentro do bioma, Felfili et al. (2004) concluíram que as áreas apresentaram alta diversidade beta, sendo que a densidade das espécies foi um fator preponderante para este resultado. Silva et al. (2006) observaram 15 unidades ecologicamente diferentes em todo o bioma, utilizando dados de solo, topografia e vegetação. A alta diversidade beta apresentada pelo bioma é portanto de extrema importância para o planejamento de áreas protegidas (RATTER et al. 1997; BRIDGEWATER et al. 2004, FELFILI et al. 2004; LEGENDRE et al. 2005), sendo assim um fator chave na definição da localização das áreas de Reserva Legal. Visto que a diversidade beta varia de acordo com a distância das áreas comparadas (CONDIT et al. 2002; CACERES et al. 2012), deve-se investigar se a escala de bioma, instituída pelo Novo Código Florestal, cumpre o objetivo de conservação da biodiversidade no Cerrado.

Também é necessário que se investigue qual a escala de microbacia, adotada pela legislação anterior, seria adequada. Bacias hidrográficas são, de forma geral, delimitações topográficas que concentram a água da chuva em um rede de drenagem (TEODORO et al. 2007). Porém, o conceito de microbacia não possui um consenso 
(TEODORO et al. 2007), podendo variar desde a área de contribuição individual de uma nascente até áreas maiores compreendendo várias nascentes. Desta forma, é necessário analisar qual dos diferentes níveis de microbacia seria adequado para a compensação de RLs.

Sendo assim, este estudo teve como objetivos a) analisar se a mudança da escala espacial admitida para compensação de RL irá promover a conservação da biodiversidade no bioma Cerrado, b) analisar a compensação de RL em diferentes escalas espaciais de microbacia e c) apresentar métricas que auxiliem na escolha da melhor escala espacial para a compensação de RL.

\section{MÉTODOS}

a) Delimitação das escalas espaciais

O bioma Cerrado foi delimitado utilizando o Mapa dos Biomas do Brasil do Instituto Brasileiro de Geografia e Estatística (IBGE 2004), que é o mapa oficial do governo brasileiro. Importante destacar que o mapa não compreende os enclaves de Cerrado localizados em outros biomas.

As microbacias foram delimitadas conforme a Agência Nacional de Águas (ANA), órgão do Governo Federal responsável pela gestão dos recursos hídricos do país. Foi utilizada uma base cartográfica que dividiu o território em seis níveis de bacias hidrográficas, adotando a codificação de Otto Pfafstetter, compondo assim as Ottobacias (ANA 2006). No nível mais detalhado (Ottobacia 6), as microbacias são delimitadas na menor área de contribuição de uma nascente; conforme vai se aumentando (Ottobacia 5, 4 e etc.), a delimitação vai compreendendo uma área maior, podendo incluir diversas nascentes. A figura 1 demonstra diversas microbacias do nível Otto5 contidas no 
interior de uma microbacia do nível Otto3, evidenciando a grande quantidade de nascentes contidas em uma única microbacia do nível 3.

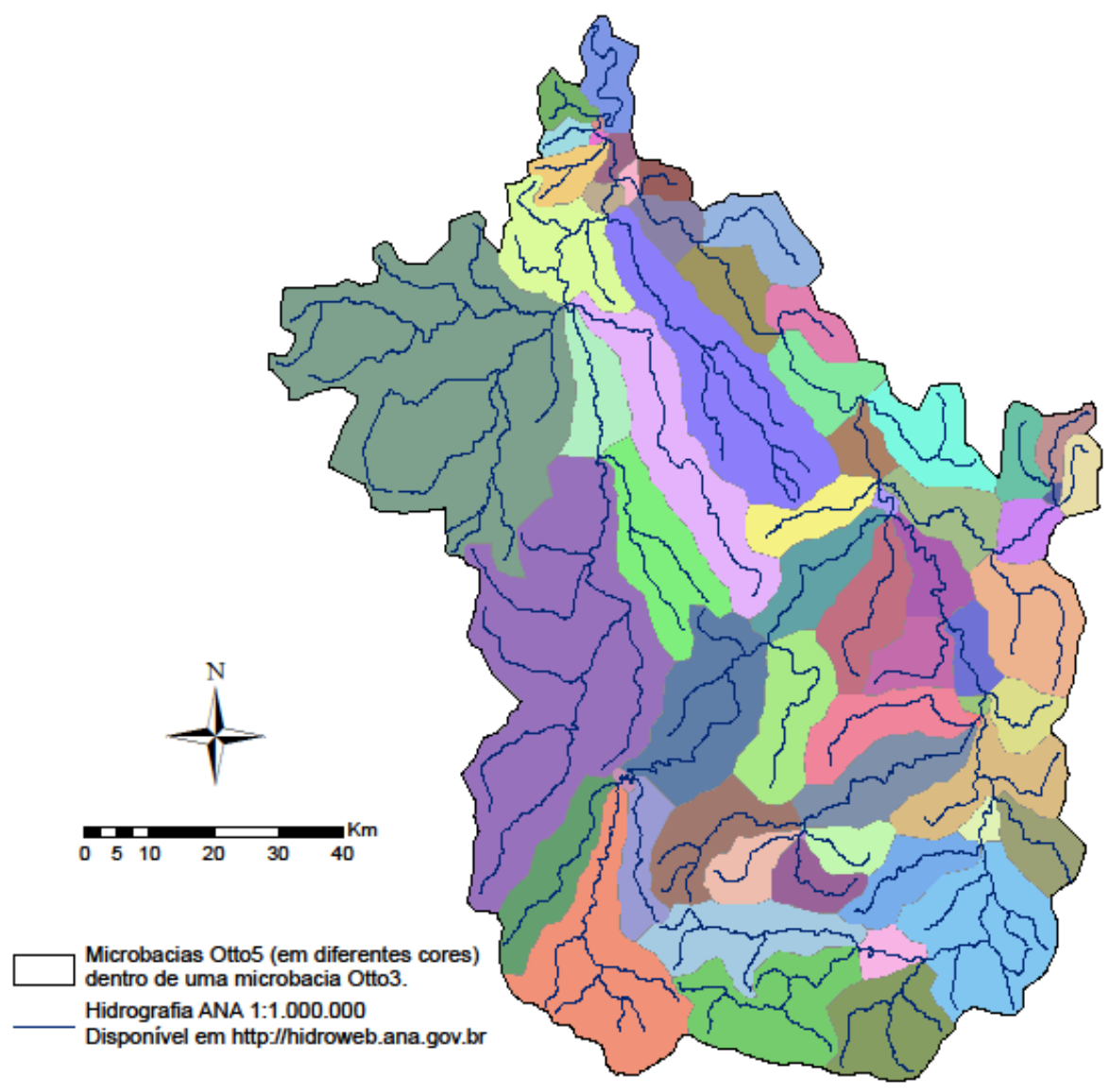

Figura 1. Microbacias do nível Otto5 (em diferentes cores) contidas em uma única microbacia do nível Otto3.

b) Cálculo da diversidade beta

A diversidade beta foi calculada através do Índice de Jaccard, que calcula a similaridade entre as microbacias 1 e 2 com a fórmula $\beta=\frac{a}{a+b+c}$, onde "a" é a quantidade de espécies comuns aos dois locais, "b" a quantidade de espécies encontradas somente na microbacia 1 e "c" a quantidade de espécies encontradas somente na microbacia 2 (MAGURRAN 2004). Considerando que não há atualmente um levantamento florístico de cada uma destas microbacias, empreender este esforço amostral demandaria anos de pesquisa para conhecer a distribuição atual das espécies. 
Porém o bioma possui, em estudos publicados e bancos de dados de herbários, milhares de pontos de ocorrência georreferenciados de espécies arbóreas, distribuídos de forma dispersa sobre o território. Uma boa ferramenta para obter dados da distribuição potencial destas espécies sobre todo o bioma, utilizando estes dados de ocorrência, é a modelagem de nicho climático (MNC) (ELITH \& LEATWICK 2009).

A MNC utiliza dados climáticos obtidos a partir de pontos de ocorrência de uma espécie para estimar seu nicho climático e delimita este nicho modelado no espaço geográfico, provendo desta forma uma delimitação da distribuição potencial desta espécie (ELITH \& LEATWICK 2009, GIANNINI et al. 2012). A MNC é uma ferramenta com crescente uso na literatura (ELITH \& LEATWICK 2009), com ampla utilização para fins conservacionistas (DE MARCO-JUNIOR \& SIQUEIRA 2009, TÔRRES \& VERCILLO 2012).

b.1) Dados de espécies

A base de dados utilizada constitui-se de levantamentos florísticos realizados no Cerrado, compilado por Françoso (2015). A base possui 50.480 registros georreferenciados de espécies vegetais lenhosas com ocorrência no Cerrado. Visto que o presente estudo objetiva levantar espécies que de forma geral representem a vegetação das Reservas Legais, as espécies de ambientes de Matas Ciliares não foram utilizadas. Assim, foram selecionadas somente as espécies com hábito arbóreo e que ocorrem em formações savânicas do bioma (RIBEIRO \& WALTER 2008), o que resultou em uma base com 17.466 registros de 124 espécies. A esta base foi acrescido o estudo desenvolvido por Mews et al. (2014), que possui um total de 1.386 registros de 243 espécies, onde foi realizado o mesmo filtro mencionado acima. Após juntar as duas bases, e selecionando somente as espécies que apresentavam mais do que 10 pontos de ocorrência, para possibilitar uma melhor performance da MNC (PEARSON et al. 2007), 
a base final apresentou um total de 17.889 pontos de ocorrência de 127 espécies. Essa escolha de um número mínimo baixo de ocorrências é importante, pois no bioma Cerrado as espécies menos frequentes é que determinam as diferenças significativas entre regiões fitogeograficamente distintas (BRIDGEWATER et al. 2004). Verificou-se para cada ponto se a localização geográfica era compatível com as informações disponíveis na base acerca de sua localização, e também se os pontos mais distantes da maioria dos outros (outliers) eram compatíveis com a distribuição geográfica da espécie disponível na literatura. Foram eliminados todos os pontos que apresentaram incompatibilidade entre as informações sobre sua localização e os pontos distantes que não condiziam com sua distribuição relatada na literatura. Após estas análises espaciais restaram 17.720 registros de 126 espécies.

b.2) Variáveis ambientais

Foram obtidas 35 variáveis ambientais no CliMond Project (KRITICOS et al. 2014) e 5 no Consortium for Spatial Information (ZOMER et al. 2007, JARVIS et al. 2008, ZOMER et al. 2008). As 40 variáveis foram submetidas a um teste de correlação para verificar a colinearidade entre elas, sendo descartadas aquelas que possuíam mais que $80 \%$ de correlação com outras (KRAMER-SHADT et al. 2013). Desta forma, as modelagens foram criadas com um total de 16 variáveis ambientais (Tabela 2). 
Tabela 2. Variáveis ambientais utilizadas na Modelagem de Nicho Climático. As duas primeiras foram obtidas no CGIAR-CSI, as restantes no CliMond.

\section{Nome Descrição}

\begin{tabular}{ll}
\hline AI & Índice Global de Aridez \\
SRTM Digital Elevation Data & Altitude \\
Bio02 & Faixa de temperatura diurna média \\
Bio03 & Oscilação diária de temperatura \\
Bio05 & Temperatura máxima da semana mais quente \\
Bio13 & Precipitação da semana mais úmida \\
Bio14 & Precipitação da semana mais seca \\
Bio15 & Sazonalidade da precipitação \\
Bio18 & Precipitação do trimestre mais quente \\
Bio19 & Precipitação do trimestre mais frio \\
Bio20 & Radiação média anual \\
Bio22 & Radiação semanal mais baixa \\
Bio24 & Radiação do trimestre mais úmido de umidade sazonal \\
Bio25 & Radiação do trimestre mais seco \\
Bio26 & Radiação do trimestre mais quente \\
\hline
\end{tabular}

Como forma de padronização, todas as variáveis foram redimensionadas para uma resolução espacial de 20 x $20 \mathrm{~km}$. Este redimensionamento estabeleceu o tamanho mínimo do pixel analisado pela modelagem, o que quer dizer que as informações ambientais extraídas para cada ponto de ocorrência são as informações de 
aproximadamente um raio de $10 \mathrm{~km}$, o que possibilita diminuir possíveis erros de coordenadas ou do georreferenciamento da base de espécies. Tais erros são comuns em bases muito extensas e retiradas de diversas fontes (SANTANA et al. 2008). Importante ressaltar que durante o processo de modelagem os pontos de ocorrência de uma espécie que estivessem localizados na mesma célula das variáveis ambientais foram considerados como um só, aspecto que diminui a autocorrelação espacial dos dados (LEGENDRE 1993, BORIA et al. 2014). Outro fator positivo da escala utilizada é que nela se diminui o efeito das interações biológicas na distribuição das espécies, visto que duas espécies podem ocorrer no mesmo pixel sem necessariamente ocorrer no mesmo local (ARAÚJO \& GUISAN 2006).

\section{b.3) Modelagem de Nicho Climático}

O algoritmo utilizado para a modelagem foi o Maxent (PHILLIPS et al. 2006) versão 3.3.3k, que produz modelos mais precisos mesmo com poucos pontos de ocorrência (PEARSON et al. 2007, WISZ et al. 2008) e também tem boa performance com maiores quantidades de pontos de ocorrência (WIZS et al. 2008). Foram geradas três unidades amostrais a partir do conjunto inicial de pontos (réplicas) para cada espécie com o objetivo de diminuir a dependência da acurácia do modelo em somente utilizar uma partição dos dados (FIELDING \& BELL 1997) e para a divisão do conjunto de dados foi utilizado o método de validação cruzada (Crossvalidate). A regra de corte (threshold) da adequabilidade ambiental utilizada foi a Maximum Training Sensitivity Plus Specificity. Esta regra de corte está adequada aos objetivos conservacionistas deste trabalho, pois diminui a sobreprevisão (LIU et al. 2005, CAO et al. 2013), que é considerada um erro importante nesta abordagem. Os modelos foram avaliados através do Teste Binomial e do cálculo do True Skill Statistics (TSS) (ALOUCHE et al. 2006). Apenas réplicas com resultado não aleatório (Teste Binomial 
com $p<0.01$ ) e TSS maior que 0.5 (OLIVEIRA et al. 2014) foram incorporadas no modelo final de cada espécie. O modelo final foi gerado a partir da multiplicação dos modelos das réplicas quando ao menos dois dos três gerados atendiam aos critérios especificados acima. Quando somente uma réplica atingia os critérios, a espécie foi eliminada do resultado final.

b.4) Análise espacial dos modelos

Após a produção dos modelos de cada espécie, foi realizada uma análise espacial no programa R Core Team (2014), versão 3.1.1, utilizando os pacotes rgeos (Bivand \& Rundel 2014), versão 0.3-6 6, maptools (Bivand \& Lewin-koh 2014), versão 0.8-30, rgdal (Bivand et al. 2014) versão 0.8-16 e raster (Hijmans 2014) versão 2.2-31. Cada modelo foi cruzado com os dados de cada microbacia, a fim de determinar quanta área de cada microbacia estava ocupada com o modelo de cada espécie. Para determinar se a espécie seria considerada presente em cada microbacia, foi estabelecido um limite de corte de $50 \%$ de presença, o que significa que somente microbacias onde o modelo da espécie ocupava ao menos $50 \%$ da área a espécie foi considerada presente.

Esta opção decorre de duas preocupações: a) visto que o pixel utilizado foi de $20 \mathrm{~km}$, somente uma parte de um pixel poderia estar no interior de uma microbacia, o que poderia indicar a presença da espécie sem que esta estivesse necessariamente presente. b) a espécie só deveria ser considerada presente em uma microbacia se ela ocorresse na maior parte da microbacia. Com isso procurou-se evitar que uma espécie que ocorresse, por exemplo, em uma área restrita de um $\mathrm{km}^{2}$ dentro de uma microbacia que possui 50 $\mathrm{km}^{2}$ fosse considerada presente. Visto que o objetivo deste estudo foi considerar cenários para troca de RLs, não faria sentido para a conservação de uma espécie se na microbacia desmatada ela ocorresse em toda a área e na microbacia compensada em 
somente uma pequena porção, pois teria a possibilidade da área compensada não abrigar a espécie.

Após esta etapa foi realizada uma análise de cluster com o uso do método de ligação Agrupamento pelas Médias Aritméticas Não Ponderadas - UPGMA (LEGENDRE \& LEGENDRE 2012), que apresentou coeficiente de correlação cofenética maior ( 0.90 em todos os cenários testados) do que os outros três métodos testados (Distância Mínima de Ward, Ligação Simples e Ligação Completa) em todos os níveis de microbacia Utilizou-se o índice de similaridade de Jaccard, a fim de verificar quais microbacias apresentavam similaridade florística entre si. Calcularam-se três níveis de similaridade (70, 80 e 90\%) em três níveis de Ottobacias (3, 4 e 5). Esta análise foi realizada utilizando o programa R Core Team (2014), versão 3.1.1, pacote vegan (Oksanen et al. 2013), versão 2.0-10.

c) Análise da perda de espécies por cenário

Realizou-se uma análise das possíveis combinações de compensação de RLs segundo as novas regras. De acordo com o NCF, a compensação pode ser realizada em qualquer local do Bioma e se fora da Unidade de Federação da propriedade original, deve se localizar em áreas consideradas prioritárias para conservação. Como forma de simular as possibilidades de compensação permitidas pelo NCF, foi utilizado o Mapa de Áreas Prioritárias para Conservação, elaborado pelo Ministério do Meio Ambiente (disponível em http://i3geo.mma.gov.br). Foram realizadas simulações em cada um dos três níveis de microbacias, considerando cada microbacia como a escala espacial delimitando as comunidades florísticas. Foi elaborada uma matriz de distância a partir do número de espécies compartilhadas entre cada microbacia, e calculada a riqueza de espécies para cada uma. Desta forma, obteve-se uma tabela Microbacia 1 (doadora) x Microbacia 2 (receptora), com o número de espécies compartilhadas entre as duas 
microbacias e a riqueza de ambas. Calculou-se quantas espécies são perdidas a cada troca de RL, a partir da subtração da riqueza da microbacia doadora pelo número de espécies compartilhadas entre as microbacias. Visto que o número de espécies perdidas depende da riqueza da microbacia doadora, realizou-se o mesmo procedimento trocando-se a ordem das microbacias, ou seja, através da relação Microbacia 2 (doadora) x Microbacia 1 (receptora). Foram analisados somente os casos nos quais, quando fora do estado da microbacia doadora, a microbacia receptora localizava-se no interior das áreas prioritárias mencionadas anteriormente. Foi calculada, para cada nível de microbacia, a porcentagem média de perda de espécies. Também se realizou o mesmo cálculo nos cenários obtidos após a análise do item anterior, simulando a compensação de RL dentro dos grupos formados a partir da análise de similaridade descrita anteriormente, sem considerar desta vez as áreas prioritárias. Por fim, foi realizada uma análise de variância para distinguir as médias significativamente diferentes. Todas as análises foram processadas no programa R Core Team (2014), versão 3.1.1, pacote vegan (Oksanen et al. 2013), versão 2.0-10.

d) Cálculo de métricas

Visto que são apresentadas nove diferentes combinações de microbacias e similaridade florística, procurou-se apresentar algumas métricas que auxiliem um eventual processo de tomada de decisão. Foram calculadas três diferentes métricas, sendo uma relacionada ao custo e duas relacionadas ao benefício ambiental de cada cenário proposto.

Para o cálculo do custo envolvido em cada cenário, buscou-se estimar o total de área a ser recuperada em cada cenário, visto que um dos maiores entraves ao cumprimento da legislação ambiental é o alto custo do reflorestamento de áreas desmatadas (SOARES-FILHO et al. 2014). Para isso, utilizaram-se os dados do Projeto 
de Monitoramento do Desmatamento dos Biomas Brasileiros por Satélite (MMA 2009), que apresenta as áreas desmatadas até 2008. Como cada cenário apresenta uma delimitação espacial onde serão admitidas as compensações de RL, foi assumido que cada região desta deveria ter o percentual mínimo de cobertura vegetal nativa exigida, conforme preconiza o NCF. Foram utilizados como percentuais 35\% para a Amazônia Legal, 30\% para o estado do Piauí (devido à Lei Estadual 5.699/2007) e 20\% para o resto do Cerrado. Assim, poderiam ocorrer possíveis trocas entre as propriedades localizadas em cada região. A área total que falta para atingir percentual mínimo deve ser reflorestada, portanto esta área foi apontada como a métrica de custo.

Para a métrica do benefício ambiental procurou-se demonstrar o quanto a recuperação das áreas pode ajudar na diminuição da fragmentação dos remanescentes florestais existentes. Espera-se que quanto maior for a área a ser recuperada, maior será a contribuição da ação para a diminuição da fragmentação da paisagem. Nesse sentido, foi aplicada uma métrica simples para avaliar esta contribuição, nomeada de Índice de Redução de Fragmentação (IRF). Em cada região que deveria ser recuperada, foi calculada a soma das distâncias mínimas entre os centróides de todos os fragmentos. Dividiu-se então o total da área a ser recuperada pela soma da distância multiplicada por 200. Como o cálculo resultou em um valor para cada região, estes foram somados para se obter um valor para cada cenário. Todas as etapas foram realizadas no programa $\mathrm{R}$ Core Team (2014), versão 3.1.1, pacotes rgeos (Bivand \& Rundel 2014) versão 0.3-6 e maptools (Bivand \& Lewin-koh 2014), versão 0.8-30. Esta métrica procurou representar o quanto a área a ser recuperada representa da quantidade de vegetação nativa necessária para implantação de corredores ecológicos com largura estipulada em 200 metros conectando todos os fragmentos. Visto que o IRF não pretende ser uma quantificação exata dos corredores ecológicos que poderiam ser implantados, mas 
somente uma métrica que compare os diferentes cenários aqui apresentados, esta largura foi estipulada de forma arbitrária. Desta forma, quanto maior o IRF, maior a diminuição da fragmentação que a vegetação a ser recuperada representa na paisagem. Também buscou-se apresentar o número de unidades de planejamento a serem recuperadas em cada cenário, o que reflete a proteção a um maior número de microbacias, produzindo um efeito positivo sobre os recursos hídricos.

\section{RESULTADOS E DISCUSSÃO}

Dos 372 modelos gerados, um total de $343(92,2 \%)$ atendeu aos critérios estabelecidos (APÊNDICE 2). Cinco espécies foram eliminadas nesta etapa. Restaram, portanto, 119 espécies (APÊNDICE 1), sendo 58 consideradas, segundo Bridgewater (2004), de ampla distribuição sobre todo bioma. As métricas apresentadas por cada modelo (TSS, Teste Binomial e AUC) seguem no APÊNDICE 2. As variáveis que apresentaram maior contribuição em cada modelo gerado foram Bio31 - Índice de umidade sazonal (em 37\% dos modelos), Bio13 - Precipitação da semana mais úmida (26\%) e Altitude (13\%). As duas primeiras, que apresentaram maior importância em mais da metade (63\%) dos modelos gerados, estão de acordo com estudos já publicados que ressaltam a importância da umidade na distribuição das espécies arbóreas do Cerrado (CASTRO \& MARTINS 1999, OLIVEIRA-FILHO \& RATTER 2002, ASSIS et al. 2011). Já a altitude é considerada um fator indireto na fisiologia das plantas, podendo na verdade representar, através de sua alta correlação, outros fatores como temperatura e precipitação (AUSTIN 2002).

A análise de cluster resultou em diferentes grupos, aqui chamados de GMI (Grupo de Microbacias Intercambiáveis) que representam o agrupamento de microbacias com a similaridade florística determinada, nos diferentes níveis analisados (Tabela 3). 
Tabela 3. Número de Grupo de Microbacias Intercambiáveis e área média de cada cenário.

\begin{tabular}{cccc}
$\begin{array}{c}\text { Microbacia } \\
\text { utilizada }\end{array}$ & $\begin{array}{c}\text { Índice de } \\
\text { Jaccard }\end{array}$ & $\begin{array}{c}\text { Número de } \\
\text { GMI }\end{array}$ & $\begin{array}{c}\text { Área média } \\
\left(\mathbf{k m}^{\mathbf{2}}\right)\end{array}$ \\
\hline Ottobacia 05 & $90 \%$ & 1.241 & $1.643,3$ \\
\hline $\begin{array}{c}\text { (4.017 } \\
\text { microbacias })\end{array}$ & $80 \%$ & 607 & $3.359,8$ \\
\hline Ottobacia 04 & $70 \%$ & 292 & $6.984,4$ \\
\hline (677 microbacias) & $80 \%$ & 392 & $5.202,6$ \\
\hline Ottobacia 03 & $70 \%$ & 250 & $8.157,8$ \\
\hline (102 microbacias) & $80 \%$ & 146 & $13.968,8$ \\
& $70 \%$ & 87 & $23.442,0$ \\
& & 66 & $30.900,8$ \\
\hline
\end{tabular}

Pode-se notar uma grande variação no número de GMIs gerados em cada cenário. Enquanto o cenário Ottobacia5 90\% apresentou 1.241 GMIs, com área média de 1.643,3 km², o cenário Ottobacia3 70\% apresentou somente 52 GMIs, com uma área média de 39.220,3 $\mathrm{km}^{2}$. Como era esperado, quanto maior foi a similaridade adotada, mais GMIs foram gerados, em todos os níveis de microbacia (Tabela 3).

A Figura 1 demonstra os GMIs agrupados por cor, evidenciando a distribuição espacial apresentada pelas unidades. Pode-se notar que os GMIs apresentam grande variação entre suas áreas, mesmo dentro de cada cenário. 


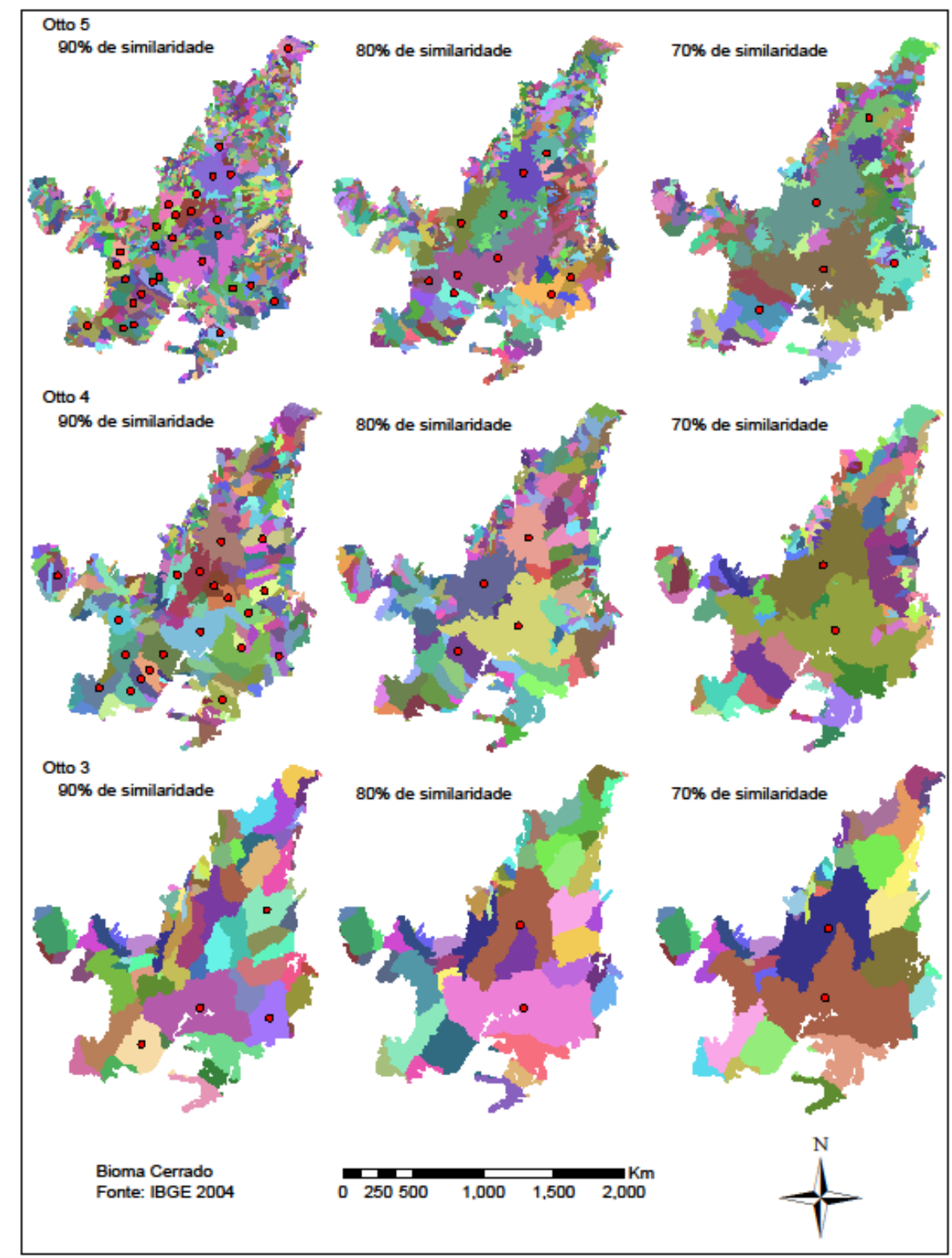

Figura 2. Cenários gerados para compensação de Reservas Legais. Cada Grupo de Microbacia Intercambiável (GMI) é representado por uma cor. Os pontos vermelhos representam GMIs com área maior do que a média $(\mathrm{p}<0,05)$.

Através do cálculo do valor de Z, identificamos as microbacias que diferem da média $(p<0,05)$ em tamanho, indicadas com um ponto vermelho nos mapas. Dois GMIs localizados no centro do bioma se destacam por apresentarem áreas maiores em praticamente todos os cenários, sendo que destes o GMI mais ao sul apresentou área maior em todos. Este fato indica que esta região do bioma possui uma área maior com alta similaridade florística. Isto pode ser explicado pela maior estabilidade climática 
apresentada durante milhares de ano por esta região central do bioma (WERNECK et al. 2012), o que pode ter produzido comunidades mais similares. O resultado em todos os cenários reforça o que já é amplamente relatado na literatura: a vegetação arbórea do Cerrado não ocorre de forma homogênea sobre toda a extensão do bioma (RATTER et al. 2003, FELFILI et al. 2004, OLIVEIRA-FILHO \& RATTER 2002, BRIDGEWATER et al. 2004).

Tabela 4. A porcentagem média e máxima de perda de espécies na compensação de Reservas Legais em cada cenário analisado. As letras diferentes ao lado das médias indicam diferença significativa entre elas $(\mathrm{p}<2 \mathrm{e}-16)$.

\begin{tabular}{lccc}
\hline \multicolumn{1}{c}{ Cenário } & $\begin{array}{c}\text { Porcentagem } \\
\text { Média }\end{array}$ & $\begin{array}{c}\text { Porcentagem } \\
\text { (número de vezes que ocorre) }\end{array}$ & $\mathrm{n}$ \\
\hline Otto3 & $53,1 \pm 30,3^{\mathrm{a}}$ & $100(491)$ & 10.158 \\
Otto4 & $50,5 \pm 30,7^{\mathrm{b}}$ & $100(13.498)$ & 411.208 \\
Otto5 & $47,7 \pm 30,3^{\mathrm{c}}$ & $100(421.297)$ & 12.472 .645 \\
Otto5 70\% & $11,3 \pm 7,2^{\mathrm{d}}$ & $50(1)$ & 1.153 .492 \\
Otto4 70\% & $11,2 \pm 7,0^{\mathrm{d}}$ & $42,4(2)$ & 28.908 \\
Otto3 70\% & $10,8 \pm 6,3^{\mathrm{de}}$ & $30(1)$ & 464 \\
Otto4 80\% & $8,4 \pm 5,5^{\mathrm{e}}$ & $32,6(1)$ & 17.260 \\
Otto5 80\% & $7,5 \pm 5,5^{\mathrm{e}}$ & $33,7(2)$ & 24.272 \\
Otto3 80\% & $7,3 \pm 4,8^{\text {ef }}$ & $20(2)$ & 44 \\
Otto3 90\% & $3,2 \pm 2,2^{\text {ef }}$ & $7,7(6)$ & 83.694 \\
Otto5 90\% & $3 \pm 2,4^{\mathrm{f}}$ & $16,4(2)$ & 2.570 \\
Otto4 $90 \%$ & $2,8 \pm 2,6^{\mathrm{f}}$ & $14,1(1)$ &
\end{tabular}

A regra instituída pelo NCF prevê que a compensação de RLs pode ser realizada em qualquer local do bioma, sendo que, se fora do estado, deve estar localizada em áreas prioritárias para conservação estaduais ou federais. Desta forma, não há qualquer mecanismo que garanta a similaridade entre as áreas. A análise das espécies compartilhadas entre possíveis trocas de RL apenas na escala de microbacia apresentou 
uma alta porcentagem média de perda de espécies (Tabela 4), atingindo maiores valores nos níveis 3 e 4 das Ottobacias $(53,1 \pm 30,3, \mathrm{n}=10.158$ e $50,5 \pm 30,7, \mathrm{n}=411.208$ respectivamente).

Já limitando as trocas dentro das GMIs, o valor foi marcadamente mais baixo, sendo as menores médias observadas nos cenários Otto5 90\% e Otto4 90\% (3 2 2,4, $\mathrm{n}=$ 83.694 e $, 2,8 \pm 2,6, \mathrm{n}=2.570$ respectivamente), sem diferença significativa entre estas $(\mathrm{p}<2$ e-16). Somente os três casos que representam a regra atual de compensação apresentaram valores máximos de perda de espécies de 100\% (Tabela 4), o que significa que nenhuma espécie presente na RL original existe na área compensada. Este fato evidencia como a atual regra de compensação pode causar sérios impactos na biodiversidade. Como as áreas doadoras da RL foram desmatadas, somente com a compensação em áreas similares se poderia garantir que a maior parte das espécies perdidas seriam conservadas na RL compensada. A conservação de espécies completamente diferentes através da compensação da RL em áreas distintas, pode levar inclusive à extinção de algumas espécies de ocorrência local (DEVELEY et al. 2010, FREITAS 2010, MARQUES et al. 2010, TOLEDO et al. 2010), principalmente em locais com poucas Unidades de Conservação (UC), onde as RLs se constituem nas únicas áreas protegidas. No Cerrado são raras as UCs em regiões de solos planos e chapadas, portanto nestes locais as RLs cumprem um papel ainda mais importante na conservação dos remanescentes nativos (MARQUES et al. 2010). Já a adoção de qualquer uma das escalas espaciais dos cenários aqui propostos garante a similaridade entre as áreas para compensação de RL, auxiliando na conservação das espécies que foram perdidas no processo de desmatamento das RLs originais. Estes resultados demonstram a importância de se incorporar uma análise de similaridade para o estabelecimento de escalas espaciais adequadas para a compensação de RLs. 
A escolha de qual cenário entre os nove apresentados é mais adequado para a compensação de RLs deve considerar diversos aspectos. Em relação ao nível de Ottobacia, a escolha certamente influenciará na qualidade e quantidade de recursos hídricos, já que cada microbacia pode abrigar uma ou dezenas de nascentes, dependendo do nível escolhido (conforme demonstrado no exemplo da Figura 1). A questão chave aqui é: qual dos três níveis permite a conservação dos recursos hídricos de forma satisfatória, considerando os cenários possíveis de localização espacial dos remanescentes florestais? Ao se escolher um nível menos detalhado, como o Otto3, deve-se considerar que cada microbacia deste nível abriga diversas nascentes. Como as áreas desmatadas tendem a se concentrar em determinadas regiões da paisagem (SPAROVECK et al. 2012), corre-se o risco de que áreas inteiras de recarga de nascentes sejam preservadas e outras permaneçam completamente desmatadas. Este fato pode causar impactos nestas nascentes, deixando-as mais suscetíveis a picos de vazão e inundações, devido à diminuição da infiltração e interceptação da água pela vegetação, além de terem seu canal diminuído pelo aumento de sedimentos (LIMA et al. 2013), impactando também a ictiofauna (CASATTI 2010). Por outro lado, em níveis mais detalhados, como o Otto5, onde cada microbacia representa poucas ou mesmo somente uma nascente (Figura 1), a proteção aos recursos hídricos é maior.

Além do nível de Ottobacia, o tamanho das GMIs também é um aspecto importante. Cada GMI deverá abrigar a porcentagem mínima exigida de RL para cada região. Considerando novamente a concentração do desmatamento em determinadas regiões da paisagem, quanto maior for a área do GMI, maior é o risco de fragmentação da vegetação remanescente, o que causa sérios impactos no Cerrado (CARVALHO et al. 2009). 
Em relação à similaridade florística a adotar, dois fatores são importantes nesta análise. Primeiro, é importante ressaltar que este estudo utilizou somente 119 espécies arbóreas e que ocorrem somente em formações savânicas do bioma. Este número é bem menor do que a quantidade estimada de espécies arbóreas desta fitofisionomia (MENDONÇA et al. 2008) e ainda menor se considerarmos as outras fitofisionomias. No entanto, também é preciso considerar que as comunidades formadas por essas espécies certamente abrigam muitas outras espécies da fauna e flora. Nas formações savânicas do Cerrado há uma predominância de espécies arbustivas-herbáceas, e sua proporção pode chegar a 5,6 para cada espécie arbórea (MENDONÇA et al. 2008). Além disso, em um hectare até 450 espécies de plantas podem ser encontradas (EITEN 1994). Isto permite afirmar que o potencial de conservação dos GMIs apresentados não se restringe somente às espécies analisadas, mesmo que comunidades formadas por espécies arbóreas possam não representar toda a diversidade de outros organismos (CUSHMAN et al. 2008). Portanto, longe de ser um mapa definitivo das microbacias com biodiversidade similar, estes resultados são uma base na qual futuros estudos, principalmente com outros organismos, possam acrescentar complexidade e estabelecer parâmetros cada vez mais confiáveis para a adoção de uma escala espacial para compensação de RL que busque uma perda mínima de biodiversidade. Segundo, a adoção de um critério de similaridade não resulta em perda efetiva desta magnitude na biodiversidade de cada microbacia. A regra atual prevê que somente RL desmatadas antes de 22/07/2008 podem realizar a compensação. Portanto os fragmentos de vegetação nativa de RL que foram desmatados após esta data terão que ser recuperados, e os que hoje existem não poderão ser desmatados, de acordo com o NCF.

Um outro aspecto importante deste estudo é que este mapeamento é realizado em uma escala regional ampla, e deve ser discutido localmente nos Comitês de Bacias 
Hidrográficas, que são fóruns com participação da sociedade civil e do governo para a gestão das bacias hidrográficas (ABERS \& JORGE 2005), ou em outras formas de organização local. Microbacias já extensamente desmatadas, ou que possuam áreas específicas com alta relevância ecológica que se encontram desmatadas podem adotar outras escalas espaciais, menores, que atendam a objetivos específicos dos Comitês. Neste caso este mapeamento também não deve ser definitivo: as condições locais devem ser consideradas para a adoção da escala espacial apropriada do GMI de cada local.

Como forma de quantificar as vantagens e desvantagens de cada cenário apresentado, as métricas são importantes para uma avaliação objetiva (Tabela 5).

Tabela 5. Métricas de cada cenário apresentado.

\begin{tabular}{c|c|c|c}
\hline \multicolumn{1}{c}{ Cenário } & Área a recuperar & Número de GMIs & Índice de Redução de \\
& $\left(\mathrm{km}^{2}\right)$ & a recuperar & Fragmentação (IRF) \\
\hline Otto5 90\% & 21.592 & 210 & 581,3 \\
\hline Otto5 80\% & 14.928 & 87 & 218,3 \\
\hline Otto5 70\% & 12.035 & 37 & 97,7 \\
\hline Otto4 90\% & 16.785 & 67 & 186,1 \\
\hline Otto4 80\% & 15.365 & 45 & 44,3 \\
\hline Otto4 70\% & 10.245 & 21 & 30,7 \\
\hline Otto3 90\% & 13.714 & 10 & 20,3 \\
\hline Otto3 80\% & 12.898 & 8 & 17,8 \\
\hline Otto3 70\% & 12.898 & 7 & \\
\hline
\end{tabular}

O cenário Otto5 90\% apresentou a maior quantidade de área a ser recuperada, o que representa um fator que é considerado um entrave para o cumprimento da legislação 
em qualquer cenário (SOARES-FILHO et al. 2014). Obviamente, sob um ponto de vista conservacionista, quanto maior a área a ser recuperada melhor, pois aumenta a quantidade de cobertura vegetal do bioma. O menor custo surpreendentemente não foi observado no cenário com GMIs de maior extensão (Otto3 70\%), mas no Otto4 $70 \%$. Os dois cenários do nível Otto3 80 e 70\% apresentaram custo idêntico. A maioria absoluta das GMIs a serem recuperadas encontram-se no sul do Cerrado, especialmente nos estados de São Paulo e Mato Grosso do Sul (Figura 3).

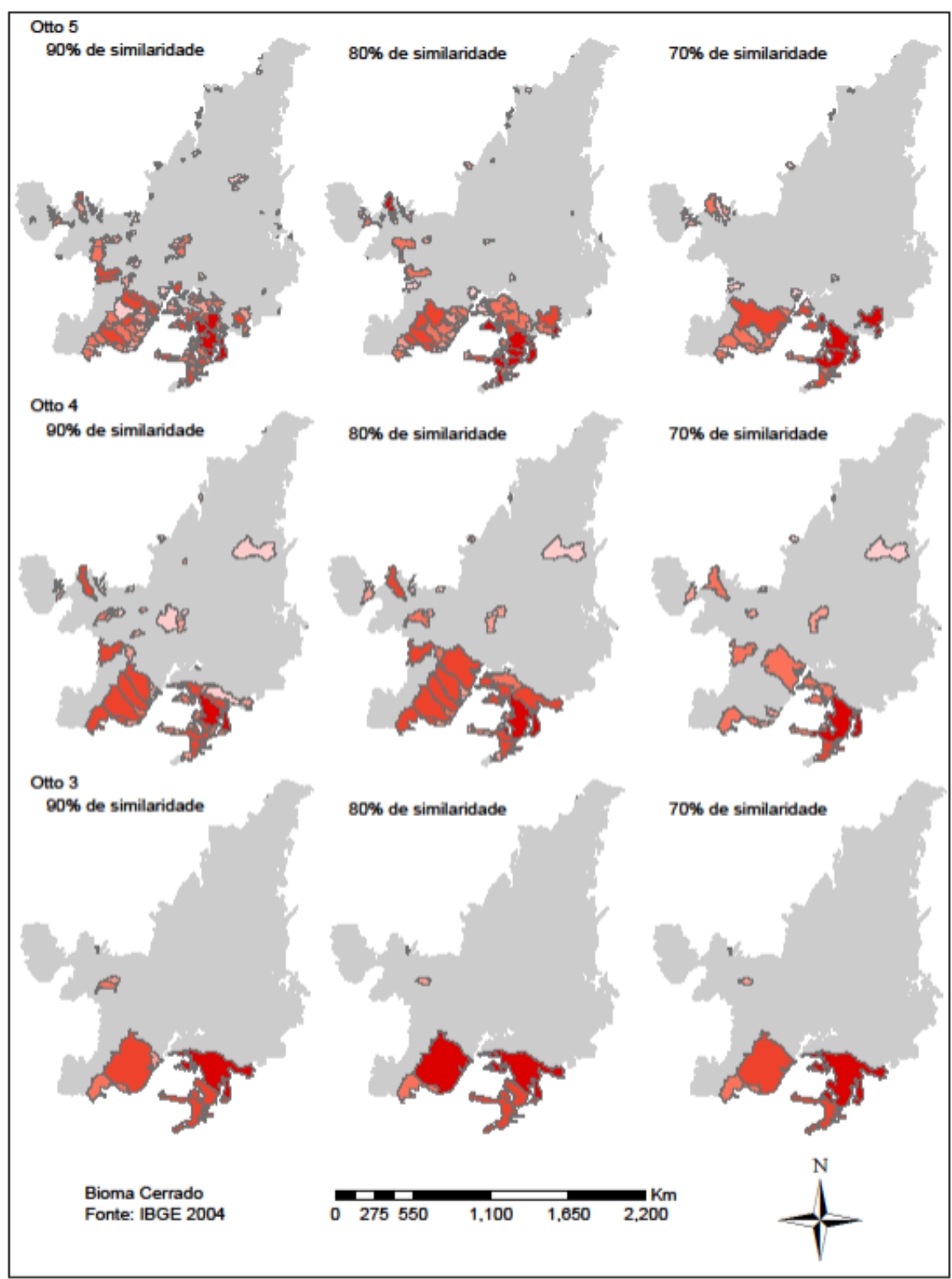

Figura 3. Grupos de Microbacias Intercambiáveis que deverão ser recuperados em cada cenário. Cores mais escuras representam áreas maiores. 
Isto reflete o padrão de desmatamento do Cerrado (MMA 2009), e também a ocupação mais antiga desta porção do bioma (SANO et al. 2010). O número de GMIs a recuperar foi marcadamente mais alto no cenário Otto5 90\%, obviamente devido às menores áreas apresentadas (Tabela 3). Esta métrica seguiu um padrão bem linear: quanto menor as áreas de GMI, menor seu número, dentro de cada nível de microbacia. Este número é importante para fornecer um indicativo da quantidade de corpos hídricos que terão aumento de cobertura vegetal em suas áreas individuais de contribuição.

O IRF seguiu exatamente o mesmo padrão do número de GMIs. Isto deve-se ao fato de que um maior número de GMIs a serem recuperados reflete uma maior subdivisão das GMIs, resultando em unidades menores, o que por sua vez aumenta a contribuição das áreas recuperadas na redução da fragmentação da paisagem. Novamente, o cenário Otto5 90\% apresentou o maior índice, sendo mais que o dobro do segundo cenário. Isto evidencia que, além de apresentar maior quantidade de área a ser recuperada, esta área está bem dividida entre as GMIs e tem uma contribuição muito maior para a redução da fragmentação do que os outros cenários. Como esperado, por apresentar os GMIs com maiores áreas, a vegetação a ser recuperada no cenário Otto3 $70 \%$ contribui de maneira bem menor para a paisagem.

Uma boa maneira de visualizar a relação de custo benefício entre os cenários é através de um fluxograma que represente a mudança de posição de cada cenário em cada um dos itens analisados (Figura 4). Neste esquema, o custo representa a quantidade de área a ser recuperada (quanto maior, mais alto o custo), o GMI representa o número de GMIs a serem recuperados (quanto maior, mais corpos hídricos protegidos) e IRF o índice calculado (quanto maior, mais redução na fragmentação). 


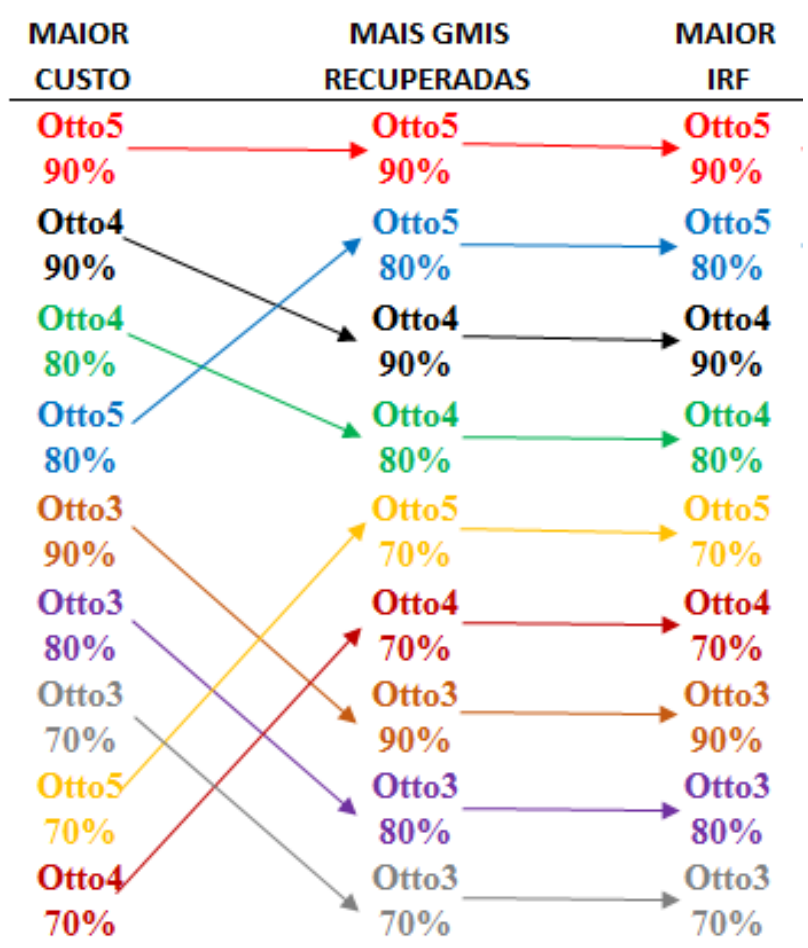

Figura 4. Posição de cada cenário em cada métrica analisada. Os cenários estão organizados em ordem decrescente de cima para baixo, e possuem a mesma cor em cada uma das métricas. Custo representa o total de área a ser recuperada, GMI, o número de GMIs a serem recuperadas e IRF o Índice de Redução da Fragmentação, para cada cenário.

O cenário que apresentou uma boa relação entre custo/benefício é o Otto5 80\%, pois apresenta somente a quarta maior área para recuperar porém o segundo maior número de GMIs a serem recuperadas e o segundo maior valor de IRF. Este cenário possui um total de 607 GMIs, com área média de 3.359,8 $\mathrm{km}^{2}$ (Tabela 3), um total de área a ser recuperada de $12.634 \mathrm{~km}^{2}$ (Tabela 5) e uma perda média de espécies de $7.5 \pm$ 5.5\% na compensação de RL (Tabela 4). Conforme já apontado, certamente a escolha do cenário ideal deve refletir uma discussão mais abrangente e é recomendável que se façam ajustes locais no desenho do cenário através dos Comitês de Bacia, porém as métricas utilizadas neste estudo permitem afirmar que este cenário pode aliar a conservação da biodiversidade e o manejo da paisagem com um menor custo para os proprietários, tornando-o adequado sob o ponto de vista social e ambiental. 


\section{CONCLUSÕES}

1. Os resultados deste estudo demonstram que a mudança de regra na compensação de Reservas Legais instituída pelo Novo Código Florestal irá permitir o estabelecimento de RLs em áreas que não tem nenhuma espécie em comum com a propriedade já desmatada, o que pode causar impactos na conservação da biodiversidade no bioma.

2. A adoção de um critério que inclua uma análise de similaridade como o apresentado neste estudo é essencial para a delimitação de escalas espaciais nas quais a compensação de RL resulte em uma perda mínima de espécies.

3. O cenário que se demonstrou mais viável, aliando maior proteção aos corpos hídricos, maior conservação de biodiversidade, maior redução da fragmentação da paisagem a um menor custo de implantação foi o nível 05 das Ottobacias com 80\% de similaridade.

4. Propõe-se que seja adotado este cenário, e que os Comitês de Bacias discutam adaptações ao desenho proposto de acordo com as especificidades locais. Espera-se que futuros estudos, principalmente com outros organismos, possam acrescentar complexidade à esta proposta, garantindo que a compensação de RLs seja realizada dentro de uma escala espacial que possa efetivamente conservar a biodiversidade do Cerrado. 


\section{REFERÊNCIA BIBLIOGRÁFICAS}

ABERS, R.; JORGE, K. Descentralização da gestão da água: por que os comitês de bacia estão sendo criados. Ambiente e Sociedade, v. 8, n. 2, p. 1-27, 2005.

ALLOUCHE, O.; TSOAR, A.; KADMON, R. Assessing the accuracy of species distribution models: prevalence, kappa and the true skill statistic (TSS). Journal of Applied Ecology, v. 43, n. 6, p. 1223-1232, 2006.

ANA. Topologia hídrica: método de construção e modelagem da base hidrográfica para suporte à gestão de recursos hídricos. Brasília, DF: Agência Nacional de Águas, 2006. p. 29

ARAÚJO, M. B.; GUISAN, A. Five (or so) challenges for species distribution modelling. Journal of Biogeography, v. 33, n. 10, p. 1677-1688, 2006.

ASSIS, A. C. C. et al. Water availability determines physiognomic gradient in an area of low-fertility soils under Cerrado vegetation. Plant Ecology, v. 212, n. 7, p. 11351147, 2011.

AUSTIN, M., Spatial prediction of species distribution: an interface between ecological theory and statistical modelling. Ecological Modelling, v. 157, n. 2-3, p. 101-118, 2002.

BIVAND, R.; KEITT, T.; ROWLINGSON, B. rgdal: Bindings for the Geospatial Data Abstraction Library. $\mathrm{R}$ package version 0.8-16: http://CRAN.Rproject.org/package=rgdal. 2014 .

BIVAND, R.; LEWIN-KOH, N. maptools: Tools for reading and handling spatial objects. R package version 0.8-30: http://CRAN.R-project.org/package=maptools. 2014.

BIVAND, R.; RUNDEL, C. rgeos: Interface to Geometry Engine - Open Source (GEOS). R package version 0.3-6: http://cran.r-project.org/package=rgeos. 2014.

BONNET, B. R. P.; FERREIRA, L. G.; LOBO, F. C. Sistema de Reserva Legal ExtraPropriedade no Bioma Cerrado: Uma Análise Preliminar no Contexto da Bacia Hidrográfica Extra-Property Legal Reserve in the Cerrado Biome: A preliminary Analysis within the Watershed Context Universidade Federal de Goiás -. v. 2, n. 58, p. 129-137, 2006.

BORIA, R. A. et al. Spatial filtering to reduce sampling bias can improve the performance of ecological niche models. Ecological Modelling, v. 275, p. 73-77, 2014.

BRASIL. Lei n ${ }^{\circ}$ 4.771, de 15 de Setembro de 1965. p. 1-8, 2014.

BRIDGEWATER, S.; RATTER, J. A.; RIBEIRO, J. F. Biogeographic patterns, bdiversity and dominance in the cerrado biome of Brazil. Biodiversity and Conservation, v. 13, p. 2295-2318, 2004.

CÁCERES, M. DE et al. The variation of tree beta diversity across a global network of forest plots. Global Ecology and Biogeography, v. 21, p. 1191-1202, 2012.

CAO, Y. et al. Using Maxent to model the historic distributions of stonefly species in Illinois streams: The effects of regularization and threshold selections. Ecological Modelling, v. 259, p. 30-39, 2013. 
CARVALHO, F. A.; FELFILI, J. M. Aplicação da diversidade alfa e beta para definição de áreas prioritárias para conservação: uma análise das florestas deciduais sobre afloramentos calcários no Vale do Paranã, Goiás. Bioscience Journal, v. 27, n. 5, p. 830-838, 2011.

CARVALHO, F. M. V; JÚNIOR, P. D. M.; FERREIRA, L. G. The Cerrado into-pieces: Habitat fragmentation as a function of landscape use in thse savannas of central Brazil. Biological Conservation, v. 142, n. 7, p. 1392-1403, 2009.

CASATTI, L. Alterações no Código Florestal Brasileiro: impactos potenciais sobre a ictiofauna. Biota Neotropica, v. 10, n. 4, p. 31-34, 2010.

CASTRO, A.; MARTINS, F. How rich is the flora of Brazilian cerrados? Annals of the Missouri ..., v. 86, n. 1, p. 192-224, 1999.

CHOMITZ, K. M. Transferable Development Rights and Forest Protection: An Exploratory Analysis. International Regional Science Review, v. 27, n. 3, p. 348-373, 2004.

CONDIT, R. et al. Beta-Diversity in Tropical Forest Trees. Science, v. 295, p. 666-669, 2002.

CUSHMAN, S. A et al. Do forest community types provide a sufficient basis to evaluate biological diversity? Frontiers in Ecology and the Environment, v. 6, n. 1, p. 13-17, 2008.

DE MARCO-JÚNIOR, P.; SIQUEIRA, M. Como determinar a distribuição potencial de espécies sob uma abordagem conservacionista. Megadiversidade, v. 5, n. 1-2, p. 65-76, 2009.

DEVELEY, P. F.; PONGILUPPI, T. Impactos potenciais na avifauna decorrentes das alterações propostas para o Código Florestal Brasileiro. Biota Neotropica, v. 10, n. 4, p. 43-45, 2010.

EITEN G. Vegetação do Cerrado. In: Cerrado: caracterização, ocupação $e$ perspectivas (ed M. N. Pinto) pp. 17-73. Editora da UnB, Brasília, D.F. 1994.

ELITH, J.; LEATHWICK, J. R. Species Distribution Models: Ecological Explanation and Prediction Across Space and Time. Annual Review of Ecology, Evolution, and Systematics, v. 40, n. 1, p. 677-697, 2009.

FELFILI, J. M. et al. Diversity, floristic and structural patterns of cerrado vegetation in Central Brazil. Plant Ecology, v. 175, p. 37-46, 2004.

FIELDING, A.; BELL, J. A review of methods for the assessment of prediction errors in conservation presence/absence models. Environmental conservation, v. 24, n. 1, p. 38-49, 1997.

FRANÇOSO, R. Padrões Biogeográficos do Cerrado. 185 p. Tese de doutorado. Brasília: Programa de Pós Graduação em Ecologia, Universidade de Brasília, 2015.

FREITAS, A. V. L. Impactos potenciais das mudanças propostas no Código Florestal Brasileiro sobre as borboletas. Biota Neotropica, v. 10, n. 4, p. 53-57, 2010.

GASTON, K. J. Global patterns in biodiversity. Nature, v. 405, p. 220-227, 2000. 
GIANNINI, T. C. et al. Desafios atuais da modelagem preditiva de distribuição de espécies. Rodriguésia, v. 63, p. 733-749, 2012.

HIJMANS, R. J. raster: Geographic data analysis and modeling. R package version 2.2-31: http://CRAN.R-project.org/package=raster. 2014.

HUTCHINSON, G. E. Homage to Santa Rosalia or Why Are There So Many Kinds of Animals? The American Naturalist, v. 93, n. 870, p. 145-159, 1959.

IBGE. Instituto Brasileiro de Geografia e Estatística. Mapa de Biomas do Brasil. Escala 1:5.000.000. IBGE, 2004.

JARVIS, A. et al. Hole-filled SRTM for the globe Version 4, available from the CGIARCSI SRTM 90m Database. 2008. Disponível em: <http://srtm.csi.cgiar.org>. Acesso em: 24 nov. 2014.

KRAMER-SCHADT, S. et al. The importance of correcting for sampling bias in MaxEnt species distribution models. Diversity and Distributions, v. 19, n. 11, p. 13661379, 2013.

KRITICOS, D. J. et al. CliMond: global high-resolution historical and future scenario climate surfaces for bioclimatic modelling. Methods in Ecology and Evolution, v. 3, n. 1, p. 53-64, 2012.

LEGENDRE, P. Spatial autocorrelation: trouble or new paradigm? Ecology, v. 74, n. 6, p. 1659-1673, 1993.

LEGENDRE, P.; BORCARD, D.; PERES-NETO, P. R. Analyzing beta diversity: Partitioning the spatial variation of community composition data. Ecological Monographs, v. 75, n. 4, p. 435-450, 2005.

LEGENDRE, P.; LEGENDRE, L. Numerical Ecology. Third Engl ed. Amsterdam, The Netherlands: Elsevier, 2012. p. 969

LEWINSOHN, T. M. A ABECO e o Código Florestal Brasileiro. Natureza \& Conservação, v. 08, n. 01, p. 100-102, 2010.

LIMA, L. S. et al. Feedbacks between deforestation, climate, and hydrology in the Southwestern Amazon: implications for the provision of ecosystem services. Landscape Ecology, v. 29, n. 2, p. 261-274, 2013.

LIU, C. et al. Selecting thresholds of occurrence in the prediction of species distributions. Ecography, v. 3, n. December 2004, p. 385-393, 2005.

MAGURRAN, A. E. Measuring Biological Diversity. Oxford, UK: Blackwell Science Ltd, 2004. p. 248

MARQUES, O. A. V. et al. Impactos potenciais das mudanças propostas no Código Florestal Brasileiro sobre os répteis brasileiros. Biota Neotropica, v. 10, n. 4, p. 39-41, 2010.

MENDONÇA, R. C. DE et al. Flora vascular do bioma Cerrado: checklist com 12.356 espécies. In: SANO, S. M.; ALMEIDA, S. P. DE; RIBEIRO, J. F. (Org.). Cerrado: ecologia e flora v.2. Brasília, DF: Embrapa Informação Tecnológica, 2008. p. 1279.

METZGER, J. P. O Código Florestal tem base científica? Natureza \& Conservação, v. 8 , n. 1, p. 1-5, 2010. 
MEWS, H. A. et al. Does size matter? Conservation implications of differing woody population sizes with equivalent occurrence and diversity of species for threatened savanna habitats. Biodiversity and Conservation, v. 23, p. 1119-1131, 2014.

MMA. Relatório técnico de monitoramento do desmatamento no bioma Cerrado, 2002 a 2008: Dados revisados. (M. do M. Ambiente, Org.). Brasília: Centro de informação, documentação ambiental e editoração Luís Eduardo Magalhães, 2009.

NEPSTAD, D. et al. Slowing Amazon deforestation through public policy and interventions in beef and soy supply chains. Science, v. 344, n. 6188, p. 1118-1123, 2014.

OKSANEN, J. et al. vegan: Community Ecology Package. R package version 2.0-10: http://CRAN.R-project.org/package=vegan. 2013.

OLIVEIRA, G. et al. Evaluating, partitioning, and mapping the spatial autocorrelation component in ecological niche modeling: a new approach based on environmentally equidistant records. Ecography, v. 37, n. 7, p. 637-647, 2014.

OLIVEIRA-FILHO, A.; RATTER, J. Vegetation physiognomies and woody flora of the cerrado biome. In: OLIVEIRA, P. S.; MARQUIS, R. J. (Org.). . The Cerrados of Brazil. Ecology and natural history of a .... New York: Columbia University Press, 2002. p. 91-120.

PANAYOTOU, T. Conservation of biodiversity and economic development: The concept of transferable development rights. Environmental and Resource Economics, v. 4, n. 1, p. 91-110, 1994.

PEARSON, R. G. et al. Predicting species distributions from small numbers of occurrence records: a test case using cryptic geckos in Madagascar. Journal of Biogeography, v. 34, n. 1, p. 102-117, 2007.

PHILLIPS, S. J.; ANDERSON, R. P.; SCHAPIRE, R. E. Maximum entropy modeling of species geographic distributions. Ecological Modelling, v. 190, p. 231-259, 2006.

R Core Team (2014). $R$ : A language and environment for statistical computing. Vienna, Austria: R Foundation for Statistical Computing. Disponível em: <http://www.rproject.org/>. Acesso em: 25 nov. 2014.

RATTER, J. A.; BRIDGEWATER, S.; RIBEIRO, J. F. Analysis of the floristic composition of the Brazilian cerrado vegetation III: comparison of the woody vegetation of 376 areas. Edinburgh Journal of ..., v. 60, n. 1, p. 57-109, 2003.

RATTER, J. A.; RIBEIRO, J. F.; BRIDGEWATER, S. The Brazilian Cerrado Vegetation and Threats to its Biodiversity. Annals of Botany, v. 80, p. 223-230, 1997.

RIBEIRO, J. F.; WALTER, B. M. T. As principais fitofisionomias do Bioma Cerrado. In: TECNOLÓGICA, E. I. (Org.). Cerrado: ecologia e flora. $1^{\text {a }}$ Edição ed. Brasília, DF: EMBRAPA, 2008. p. 153-212.

SANO, E. E. et al. Land cover mapping of the tropical savanna region in Brazil. Environ Monit Assess, v. 166, n. 1-4, p. 113-124, 2010.

SANTANA, F. S. et al. A reference business process for ecological niche modelling. Ecological Informatics, v. 3, n. 1, p. 75-86, 2008. 
SILVA, J. A. A. et al. O Código Florestal e a Ciência: contribuições para o diálogo. São Paulo: SBPC, Sociedade Brasileira para o Progresso da Ciência ABC, Academia Brasileira de Ciências, 2011. p. 124

SILVA, J. F. et al. Spatial heterogeneity, land use and conservation in the cerrado region of Brazil. Journal of Biogeography, v. 33, n. 3, p. 536-548, 2006.

SOARES-FILHO, B. et al. Cracking Brazil's Forest Code. Science, v. 344, n. 6182, p. 363-364, 2014.

SPAROVEK, G. et al. The revision of the Brazilian Forest Act: increased deforestation or a historic step towards balancing agricultural development and nature conservation? Environmental Science \& Policy, v. 16, p. 65-72, 2012.

TEODORO, V. L. I. et al. O conceito de bacia hidrográfica e a importância da caracterização morfométrica para o entendimento da dinâmica ambiental local. Revista Uniara, v. 20, p. 137-155, 2007.

TOLEDO, L. F. et al. A revisão do Código Florestal Brasileiro: impactos negativos para a conservação dos anfíbios. Biota Neotropica, v. 10, n. 4, p. 35-38, 2010.

TÔRRES, N.; VERCILLO, U. Como ferramentas de modelagem de distribuição de espécies podem subsidiar ações de governo. Natureza \& Conservação, v. 10, n. December, p. 228-230, 2012.

WERNECK, F. P. et al. Climatic stability in the Brazilian Cerrado: implications for biogeographical connections of South American savannas, species richness and conservation in a biodiversity hotspot. Journal of Biogeography, v. 39, n. 9, p. 16951706, 2012.

WHITTAKER, R. H. Vegetation of the Siskiyou Mountains, Oregon and California. Ecological Monographs, v. 30, p. 279-338, 1960.

WISZ, M. S. et al. Effects of sample size on the performance of species distribution models. Diversity and Distributions, v. 14, n. 5, p. 763-773, 2008.

ZOMER, R. J. et al. Climate change mitigation: A spatial analysis of global land suitability for clean development mechanism afforestation and reforestation. Agriculture, Ecosystems \& Environment, v. 126, n. 1-2, p. 67-80, 2008.

ZOMER, R. J. et al. Trees and water: smallholder agroforestry on irrigated lands in Northern India. (I. W. M. Institute, Org.). Colombo: [s.n.], 2007. Disponível em: <http://ageconsearch.umn.edu/bitstream/53067/2/RR122.pdf>. Acesso em: 24 nov. 2014 


\section{CONSIERAÇÕES FINAIS}

A principal legislação ambiental do país, o Código Florestal, foi modificada em 2012. Apesar das inúmeras críticas e sugestões apontadas em trabalhos científicos durante o processo de concepção da lei (ver Capítulo 1), a maior parte da legislação contrariou estes apontamentos. A Reserva Legal (RL), área protegida em propriedades privadas, se constitui hoje no dispositivo que conserva a maior parte da vegetação nativa do país (SPAROVECK et al. 2012), evidenciando sua grande importância para a conservação dos ecossistemas nativos. Mesmo assim, a nova legislação flexibilizou de maneira notável as formas de regularização dos imóveis que desmataram a RL antes de 22/07/2008. Estima-se que só no Cerrado haverá uma redução de 3,7 Mha nas exigências de RL com a nova legislação (SOARES-FILHO et al. 2014). Apesar do propalado benefício social da concessão de anistia nas RLs (ver Capítulo 1), demonstramos que no Cerrado os efeitos serão acentuadamente desiguais entre as Unidades da Federação, beneficiando algumas de forma ampla e outras de maneira bem menos expressiva (ver Capítulo 2). Ressalta-se que as Unidades de Conservação, áreas públicas de conservação, também vem sendo afetadas através de políticas públicas, com desafetações e diminuições de área, principalmente no período de 2008 a 2012 (BERNARD et al. 2014), e com a previsão de instalação de diversos projetos de mineração e geração de energia dentro de seus limites (FERREIRA et al. 2014).

Além da redução de área de RL, através da anistia, a flexibilização do mecanismo de compensação (através do qual um proprietário pode manter sua RL fora da propriedade) pode causar sérios impactos sobre a biodiversidade. A nova regra instituída pelo NCF permite que RLs com espécies completamente diferentes da propriedade original possam ser utilizadas para compensação, o que pode causar um expressivo impacto sobre a conservação da biodiversidade (ver Capítulo 3). Este 
aspecto do NCF foi amplamente criticado em publicações científicas (ver Capítulo 1), porém foi implementado assim mesmo, evidenciando de forma clara a falta de subsídios científicos em diversas mudanças do NCF (SPAROVECK et al. 2012). Isto ressalta a importância de se analisarem os impactos do NCF sobre a biodiversidade, e de se apontarem alternativas que possam ser viáveis para a conservação, como por exemplo os cenários propostos nesta pesquisa para a compensação de RL no Cerrado (ver Capítulo 3).

Evidentemente, a elaboração de uma legislação como o NCF é extremamente complexa, e deve atender a diversos interesses da sociedade. O próprio NCF foi criticado tanto por ambientalistas quanto por setores do agronegócio (SOARES-FILHO et al. 2014). Porém, deve-se atentar que a falta de critérios científicos para o estabelecimento das regras pode produzir benefícios pouco amplos com sérios impactos sobre a conservação da biodiversidade (vide os exemplos do Capítulo 2 e 3). Equacionar os benefícios demandados pelo setor ruralista com a necessidade da conservação de nossos ecossistemas é um desafio sobre o qual a ciência deve se debruçar de forma proativa. A falsa dicotomia entre conservação e produção agrícola (SPAROVECK et al. 2012) deve ser demonstrada com propostas concretas e viáveis, construindo de forma paulatina um consenso na sociedade. Portanto, é de extrema importância que sejam realizadas mais pesquisas como esta, investigando de forma minuciosa os efeitos que a nova legislação terá sobre os biomas brasileiros e apresentando propostas que possam aprimorar o NCF.

Por fim, ressalta-se que não é somente uma legislação equilibrada que garante a conservação dos recursos naturais. A experiência positiva da Amazônia na redução do desmatamento demonstra que a governança, acordos na cadeia produtiva, articulação interinstitucional, programas de incentivo, restrição ao crédito e fiscalização (ARIMA et 
al. 2014, NESPTAD et al. 2014) são fatores essenciais para garantir o cumprimento da lei de forma decisiva. Porém, devemos atentar para que o sucesso da política pública na Amazônia não transfira a pressão de desmatamento para outros biomas, particularmente o Cerrado (ARIMA et al. 2014), onde não há no momento este esforço governamental tão consolidado. Atualmente, a taxa de desmatamento do Cerrado já é maior do que da Amazônia (SOARES-FILHO et al. 2014). Espera-se que as iniciativas governamentais que obtiveram este grande êxito na Amazônia possam ser replicadas para os outros biomas, garantindo a proteção de cada ecossistema brasileiro.

\section{REFERÊNCIAS BIBLIOGRÁFICAS}

ARIMA, E. Y. et al. Public policies can reduce tropical deforestation: Lessons and challenges from Brazil. Land Use Policy, v. 41, p. 465-473, nov. 2014.

BERNARD, E.; PENNA, L. A O.; ARAÚJO, E. Downgrading, downsizing, degazettement, and reclassification of protected areas in Brazil. Conservation Biology, v. 28 , n. 4, p. 939-50, 2014.

FERREIRA, J. C. et al. Brazil's environmental leadership at risk mining and dams threaten protected areas. Science, v. 346, n. 6210, p. 706-707, 2014.

NEPSTAD, D. et al. Slowing Amazon deforestation through public policy and interventions in beef and soy supply chains. Science, v. 344, n. 6188, p. 1118-1123, 2014.

SOARES-FILHO, B. et al. Cracking Brazil's Forest Code. Science, v. 344, n. 6182, p. 363-364, 2014.

SPAROVEK, G. et al. The revision of the Brazilian Forest Act: increased deforestation or a historic step towards balancing agricultural development and nature conservation? Environmental Science \& Policy, v. 16, p. 65-72, 2012. 


\section{APÊNDICE 1}

Lista das 119 espécies utilizadas na modelagem, ordenadas por família.

\section{Anacardiaceae}

Anacardium occidentale L.

Astronium fraxinifolium Schott

Annonaceae

Annona crassiflora Mart.

Cardiopetalum calophyllum Schltdl.

Xylopia aromatica (Lam.) Mart.

\section{Apocynaceae}

Aspidosperma macrocarpon Mart.

Aspidosperma multiflorum A.DC.

Aspidosperma nobile Müll.Arg.

Aspidosperma tomentosum Mart.

Hancornia speciosa Gomes

\section{Araliaceae}

Schefflera macrocarpa (Cham. \& Schltdl.) Frodin

\section{Asteraceae}

Eremanthus arboreus (Gardner) MacLeish

Eremanthus glomeratus Less.

Eremanthus glomerulatus Less.

Eremanthus incanus (Less.) Less.

Wunderlichia mirabilis Riedel ex Baker

Bignoniaceae

Cybistax antisyphilitica (Mart.) Mart.

Handroanthus ochraceus (Cham.) Mattos

Jacaranda brasiliana (Lam.) Pers.

Tabebuia aurea (Silva Manso) Benth. \& Hook.f. ex S.Moore

Boraginaceae

Cordia glabrata (Mart.) A.DC.

Burseraceae

Protium heptaphyllum (Aubl.) Marchand

Caryocaceae

Caryocar brasiliense Cambess.

Caryocar coriaceum Wittm.

Caryocar cuneatum Wittm.

\section{Celastraceae}

Plenckia populnea Reissek

\section{Chrysobalanaceae}

Couepia grandiflora (Mart. \& Zucc.) Benth.

Hirtella ciliata Mart. \& Zucc.

Hirtella glandulosa Spreng.

Licania sclerophylla (Hook.f.) Fritsch

\section{Clusiaceae}


Kielmeyera coriacea Mart. \& Zucc.

Kielmeyera grandiflora (Wawra) Saddi

Kielmeyera lathrophyton Saddi

Platonia insignis Mart.

\section{Combretaceae}

Combretum mellifluum Eichler

Terminalia argentea Mart.

Terminalia fagifolia Mart.

\section{Dilleniaceae}

Curatella americana $\mathrm{L}$.

\section{Ebenaceae}

Diospyros hispida A.DC.

Diospyros sericea A.DC.

\section{Erythroxylaceae}

Erythroxylum deciduum A.St.Hil.

\section{Euphorbiaceae}

Mabea fistulifera Mart.

Sapium haematospermum Müll.Arg.

\section{Fabaceae}

Andira cordata Arroyo ex R.T.Penn. \& H.C.Lima

Andira cujabensisBenth.

Andira vermifuga (Mart.) Benth.

Bowdichia virgilioides Kunth

Cenostigma macrophyllum Tul.

Copaifera langsdorffii Desf.

Dalbergia miscolobium Benth.

Dimorphandra gardneriana Tul.

Dimorphandra mollis Benth.

Dipteryx alata Vogel

Enterolobium gummiferum (Mart.) J.F.Macbr.

Hymenaea stigonocarpa Mart. ex Hayne

Leptolobium dasycarpum Vogel

Leptolobium elegans Vogel

Luetzelburgia auriculata (Allemão) Ducke

Machaerium acutifolium Vogel

Parkia platycephala Benth

Peltogyne confertiflora (Mart. ex Hayne) Benth.

Plathymenia reticulata Benth.

Pterodon emarginatus Vogel

Pterodon pubescens (Benth.) Benth.

Senna silvestris (Vell.) H.S.Irwin \& Barneby

Tachigali aurea Tul.

Tachigali subvelutina (Benth.) Oliveira-Filho

Tachigali vulgaris L.G.Silva \& H.C.Lima

Vatairea macrocarpa (Benth.) Ducke

\section{Icacinaceae}


Emmotum nitens (Benth) Miers

Lecythidaceae

Eschweilera nana (O.Berg) Miers

Loganiaceae

Strychnos pseudoquina A.St.-Hil.

Lythraceae

Lafoensia pacari A.St.-Hil.

Malpighiaceae

Heteropterys campestris A.Juss.

Malvaceae

Eriotheca gracilipes (K.Schum.) A.Robyns

Eriotheca pubescens (Mart. \& Zucc.) Schott \& Endl.

Pseudobombax longiflorum (Mart. \& Zucc.)

Pseudobombax tomentosum (Mart. \& Zucc.)

Meliaceae

Cedrela fissilis Vell.

Moraceae

Ficus citrifolia Mill.

Myristicaceae

Virola sebifera Aubl.

Myrtaceae

Blepharocalyx salicifolius (Kunth) O.Berg

Eugenia dysenterica DC.

Myrcia multiflora (Lam.) DC.

Myrcia tomentosa (Aubl.) DC.

Psidium myrtoides O.Berg

Nyctaginaceae

Guapira graciliflora (Mart. ex Schmidt) Lundell

Guapira noxia (Netto) Lundell.

\section{Opiliaceae}

Agonandra brasiliensis Miers ex Benth. \& Hook. f.

Primulaceae

Cybianthus detergens Mart.

Myrsine guianensis (Aubl.) Kuntze

Proteaceae

Roupala montana Aubl.

Rosaceae

Prunus myrtifolia (L.) Urb.

Rubiaceae

Alibertia edulis (Rich.) A.Rich.

Cordiera sessilis (Vell.) Kuntze

Rutaceae

Zanthoxylum rhoifolium Lam.

Zanthoxylum riedelianum Engl.

Salicaceae

Casearia grandiflora Cambess. 
Casearia sylvestris $\mathrm{Sw}$.

Sapindaceae

Cupania vernalis Cambess.

Magonia pubescens A.St.-Hil.

Sapotaceae

Pouteria ramiflora (Mart.) Radlk.

Pouteria torta (Mart.) Radlk.

Styracaceae

Styrax ferrugineus Nees \& Mart.

Symplocaceae

Symplocos rhamnifolia A.DC.

Urticaceae

Cecropia pachystachya Trécul

Vochysiaceae

Callisthene fasciculata Mart.

Qualea cordata (Mart.) Spreng.

Qualea dichotoma (Mart.) Warm.

Qualea grandiflora Mart.

Qualea multiflora Mart.

Qualea parviflora Mart.

Salvertia convallariodora A.St.Hil.

Vochysia cinnamomea Pohl

Vochysia elliptica Mart.

Vochysia gardneri Warm.

Vochysia haenkeana Mart.

Vochysia rufa Mart.

Vochysia thyrsoidea Pohl 


\section{APÊNDICE 2}

Modelos finais já cortados pelo threshold, com o valor de TSS, AUC e valor de p do teste binomial.


Anacardium occidentale TSS. 0.76

AUC. 0.95

Bin. prob. 5.63333973333333e-58
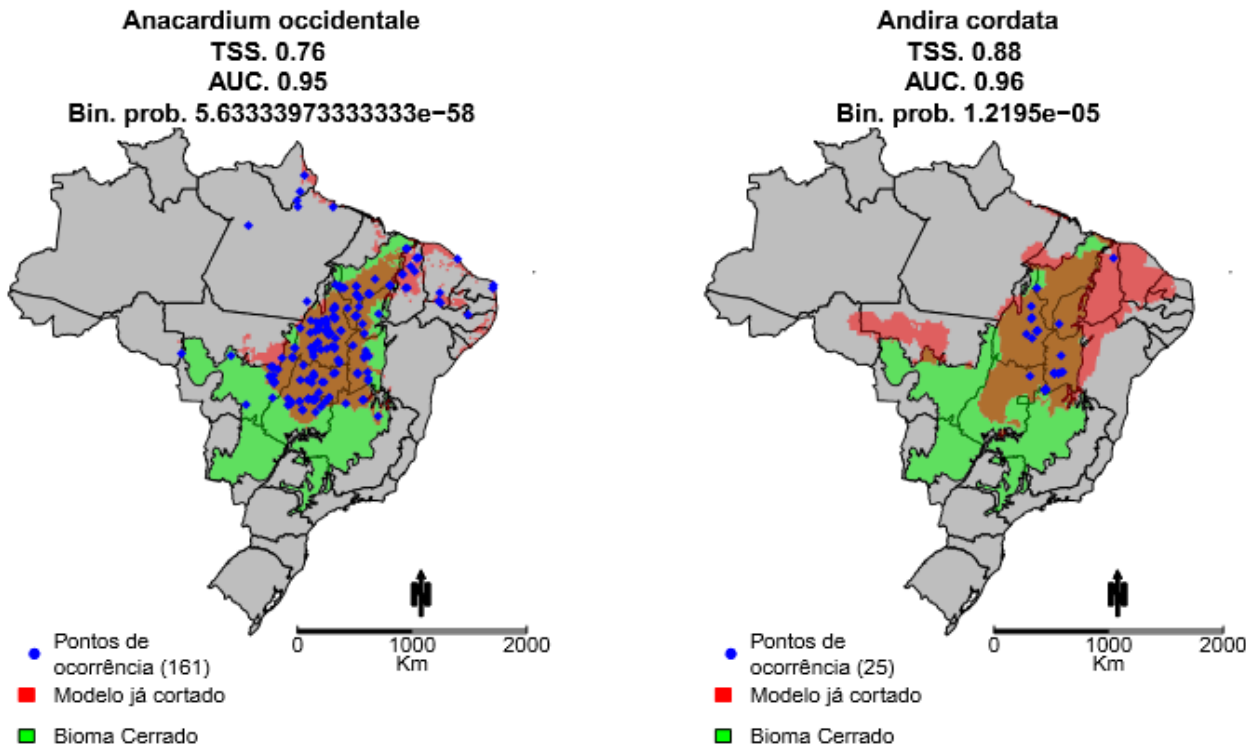
Andira cujabensis

TSS. 0.76

AUC. 0.94

Bin. prob. 1.76480000014533e-35

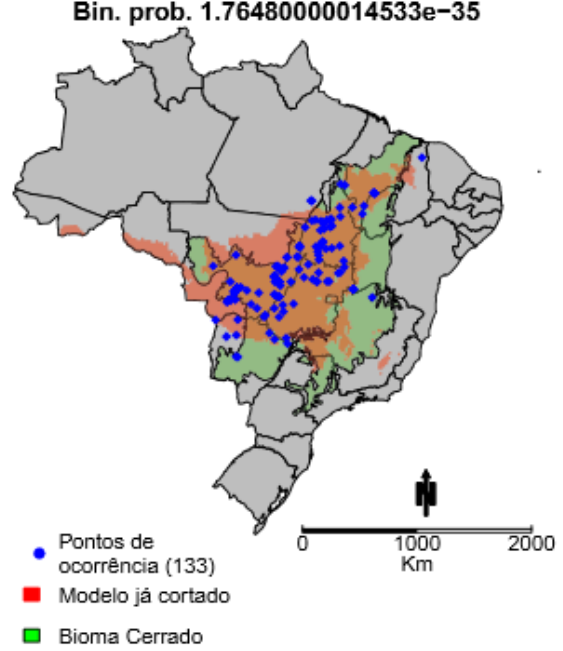

Bioma Cerrado

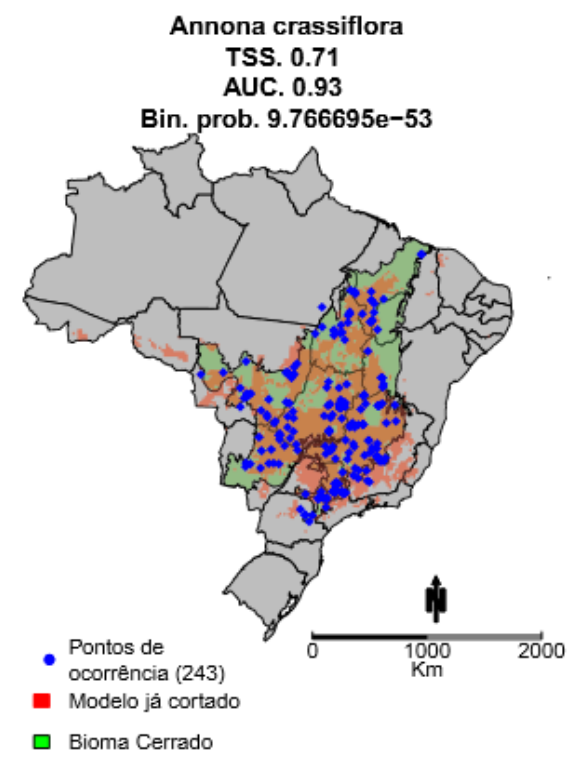

Andira vermifuga

TSS. 0.61

AUC. 0.94

Bin. prob. 4.77832333333333e-57



Aspidosperma macrocarpon

TSS. 0.75

AUC. 0.94

Bin. prob. 0

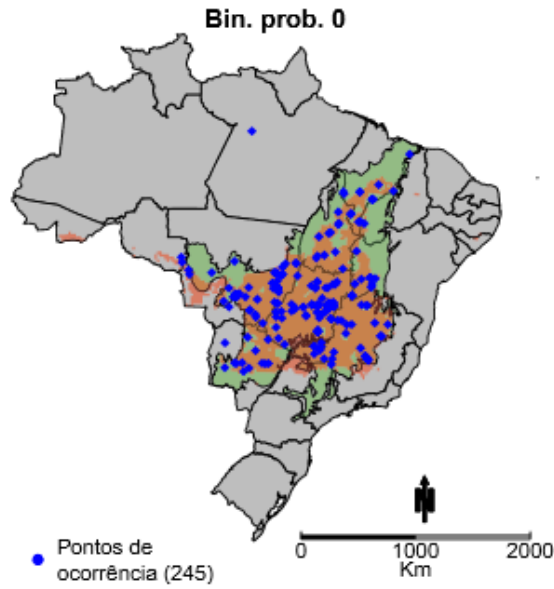

- ocorrencia (245)

- Modelo já cortado

$\square$ Bioma Cerrado 
Aspidosperma multiflorum

$$
\text { TSS. } 0.70
$$

AUC. 0.95

Bin. prob. $\mathbf{0 . 0 0 0 1 5 1 2 2 9 6 3 3 3 3 3 3 3 3}$

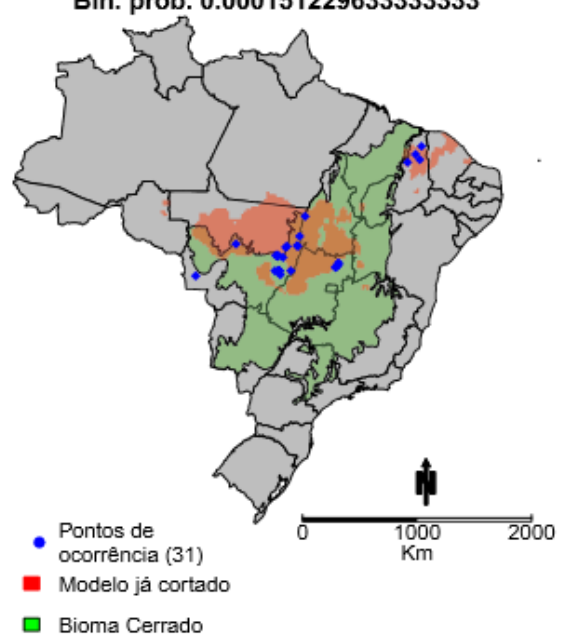

ㅁ Bioma Cerrado



Aspidosperma nobile

TSS. 0.80

AUC. 0.96

Bin. prob. 2.735666954e-42

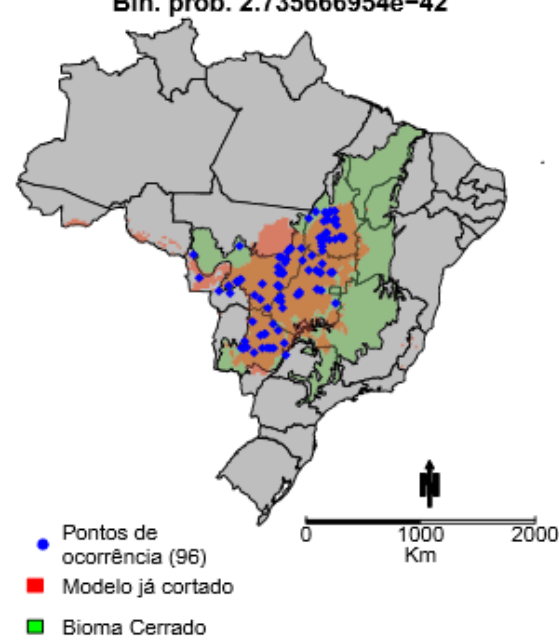

Astronium fraxinifolium TSS. 0.59

AUC. 0.92

Bin. prob. 1.00333604666667e-59

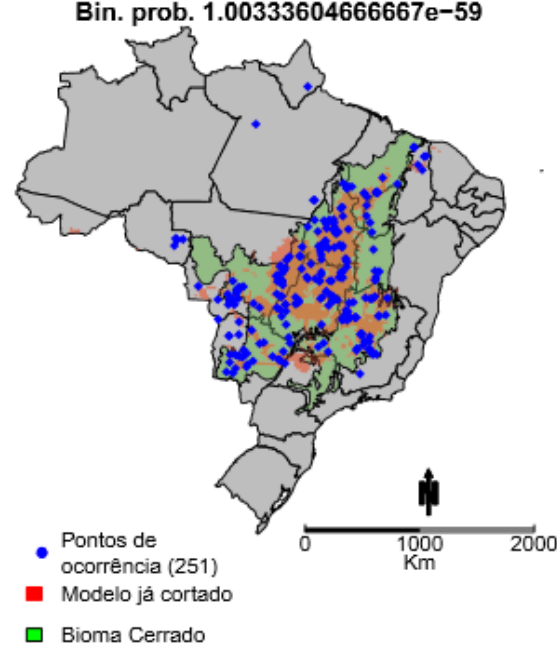


Blepharocalyx salicifolius

TSS. 0.72

AUC. 0.93

Bin. prob. 3.78666666666667e-08

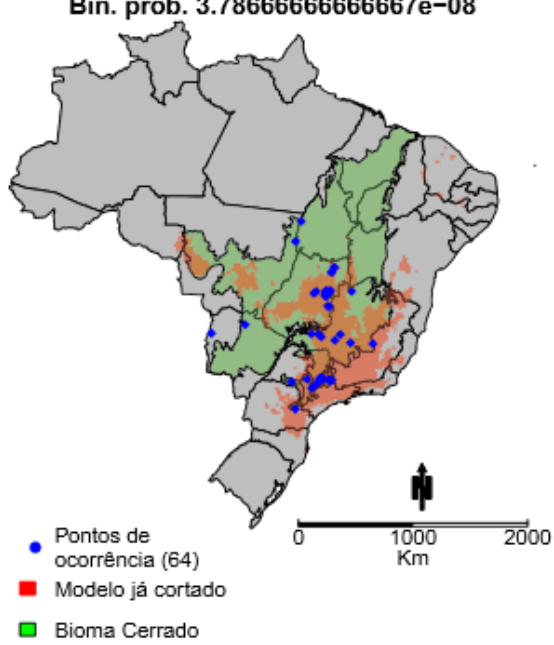

Callisthene fasciculata

TSS. 0.66

AUC. 0.93

Bin. prob. 4.76400170333333e-22

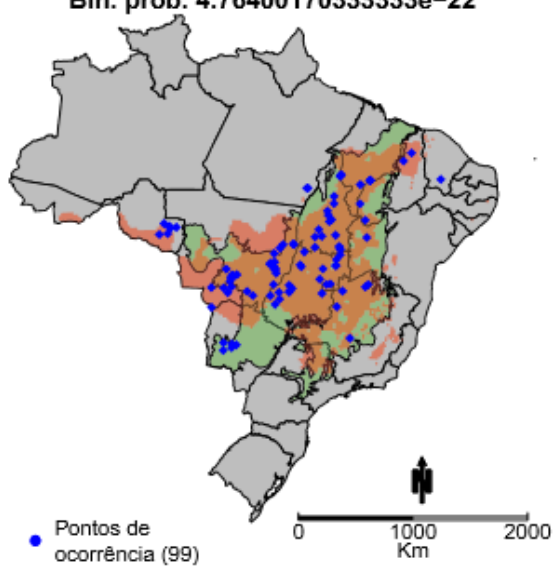

- ocorrencia (99)

2000

- Modelo já cortado

$\square$ Bioma Cerrado

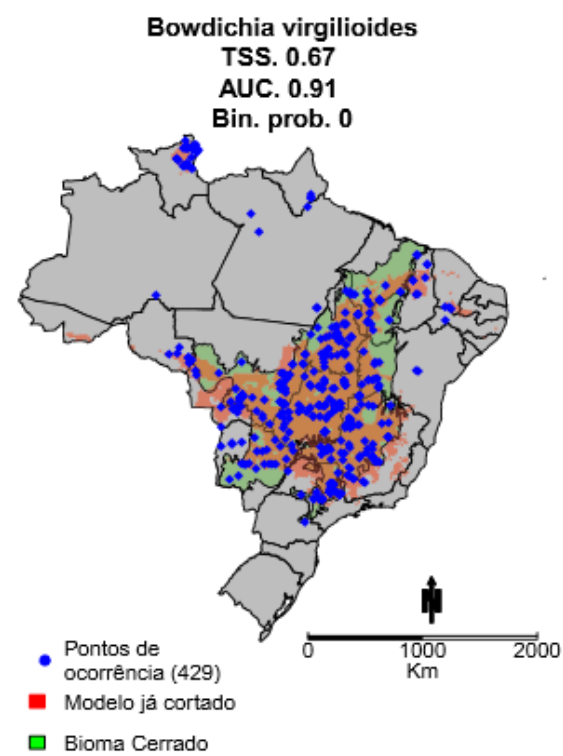

Cardiopetalum calophyllum

$$
\text { TSS. } 0.77
$$$$
\text { AUC. } 0.94
$$

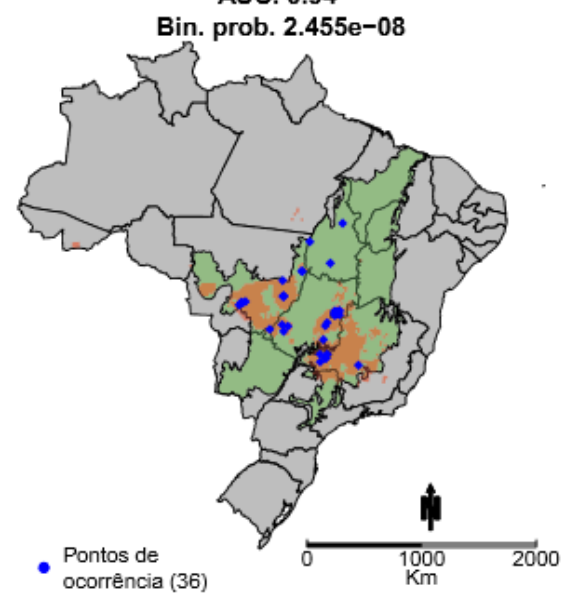

- ocorrência (36)

- Modelo já cortado

$\square$ Bioma Cerrado 



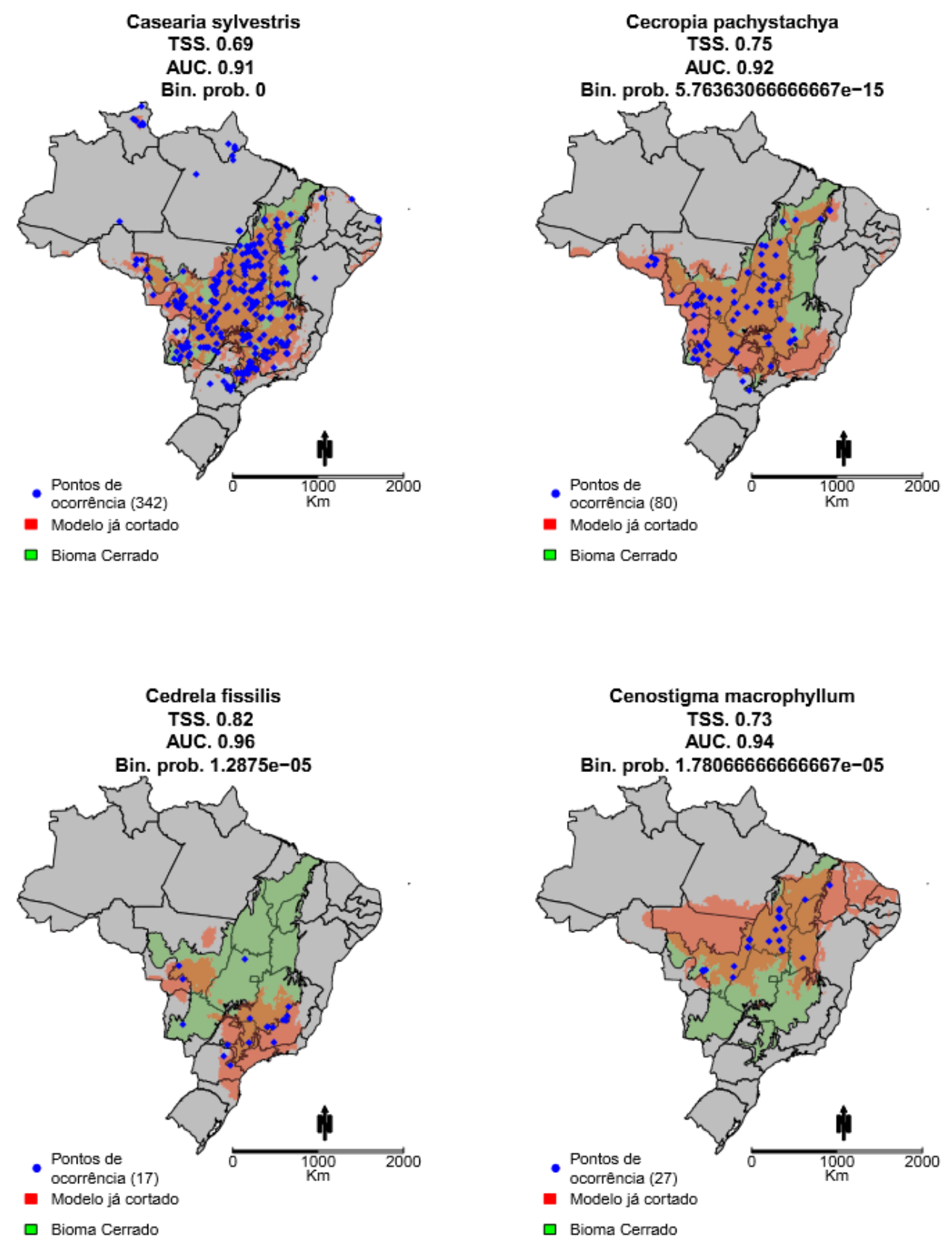

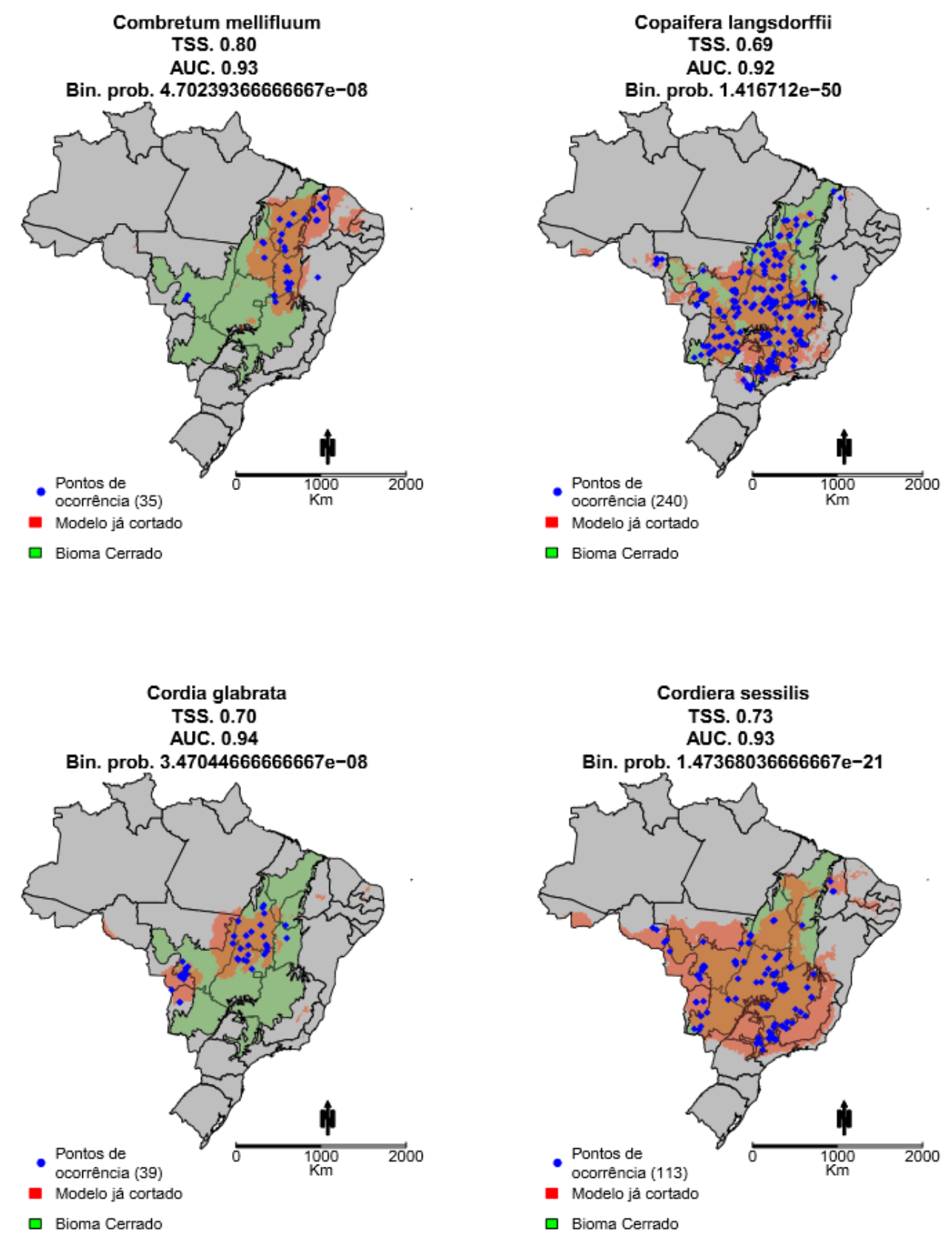

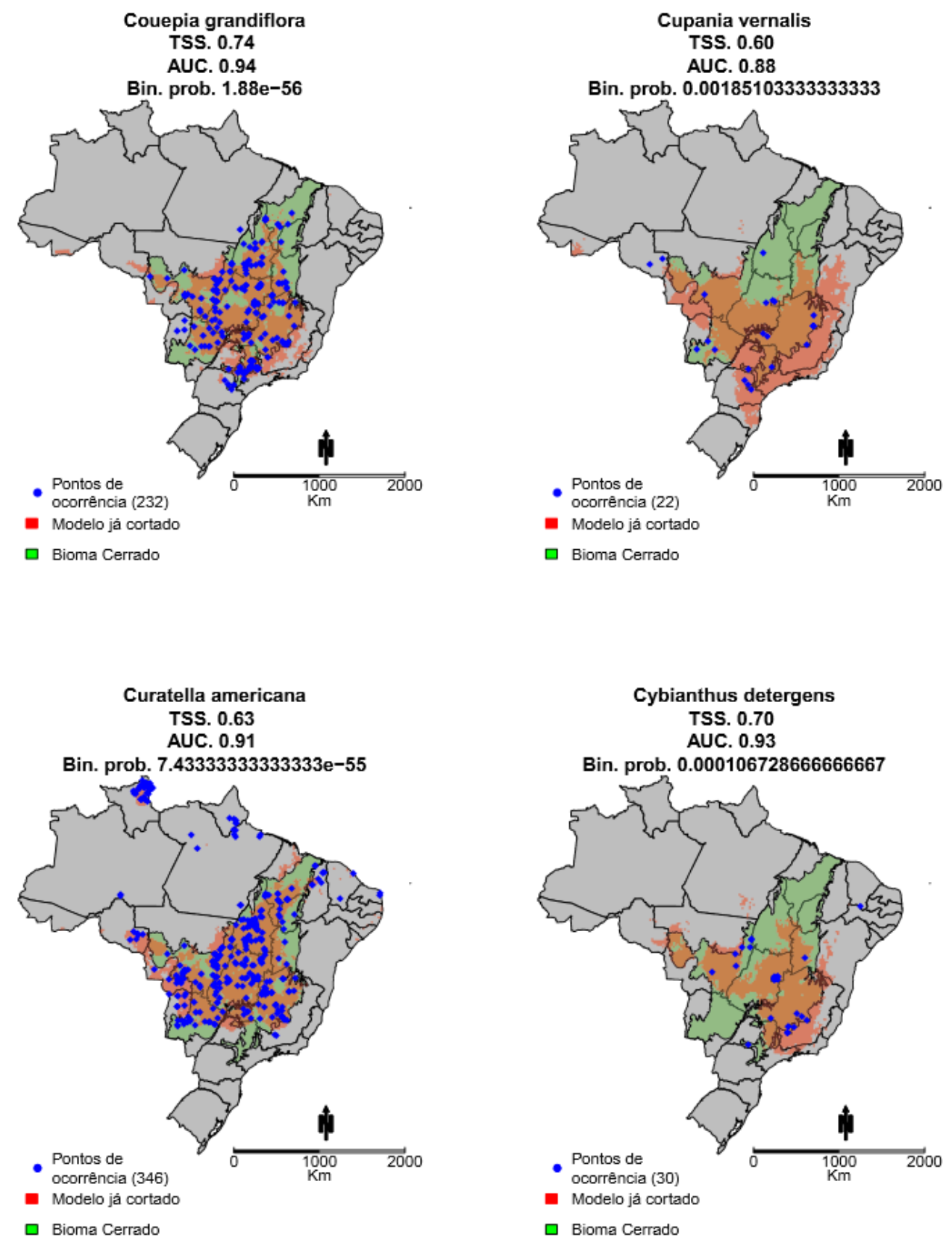
Cybistax antisyphilitica

TSS. 0.73

AUC. 0.92

Bin. prob. 1.05822333333333e-38

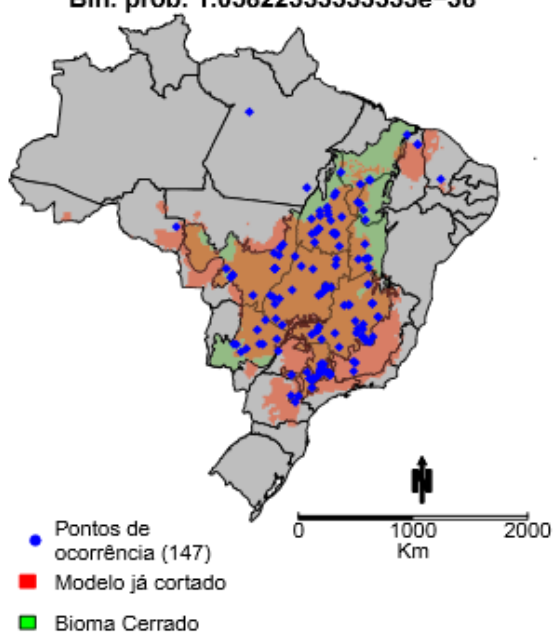

口 Bioma Cerrado

Dimorphandra gardneriana

$$
\text { TSS. } 0.81
$$

AUC. 0.95

Bin. prob. 0.00161693333333333

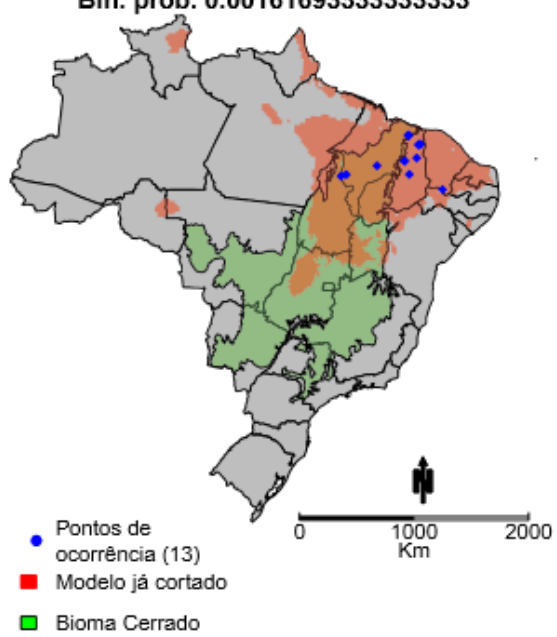

Dalbergia miscolobium

TSS. 0.72

AUC. 0.93

Bin. prob. 2.25666864666667e-54

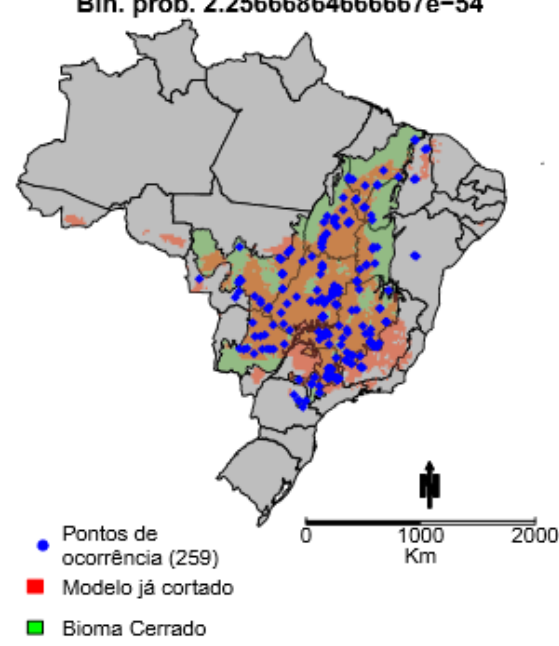

Dimorphandra mollis

TSS. 0.77

AUC. 0.94

Bin. prob. 0

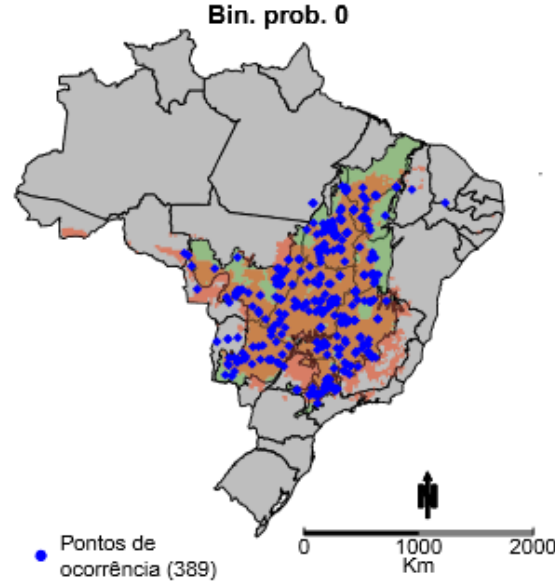

- Modelo já cortado

๑ Bioma Cerrado 

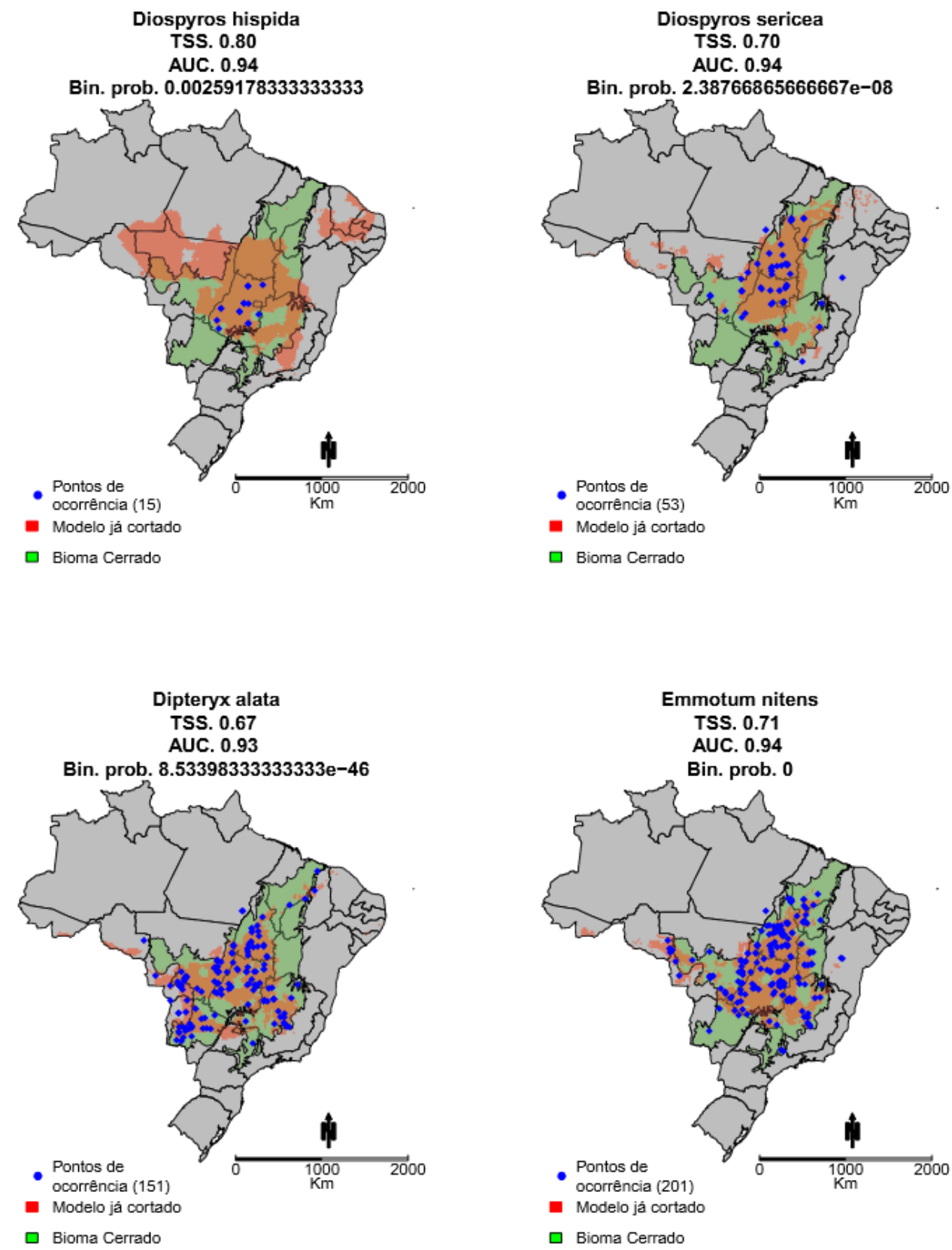

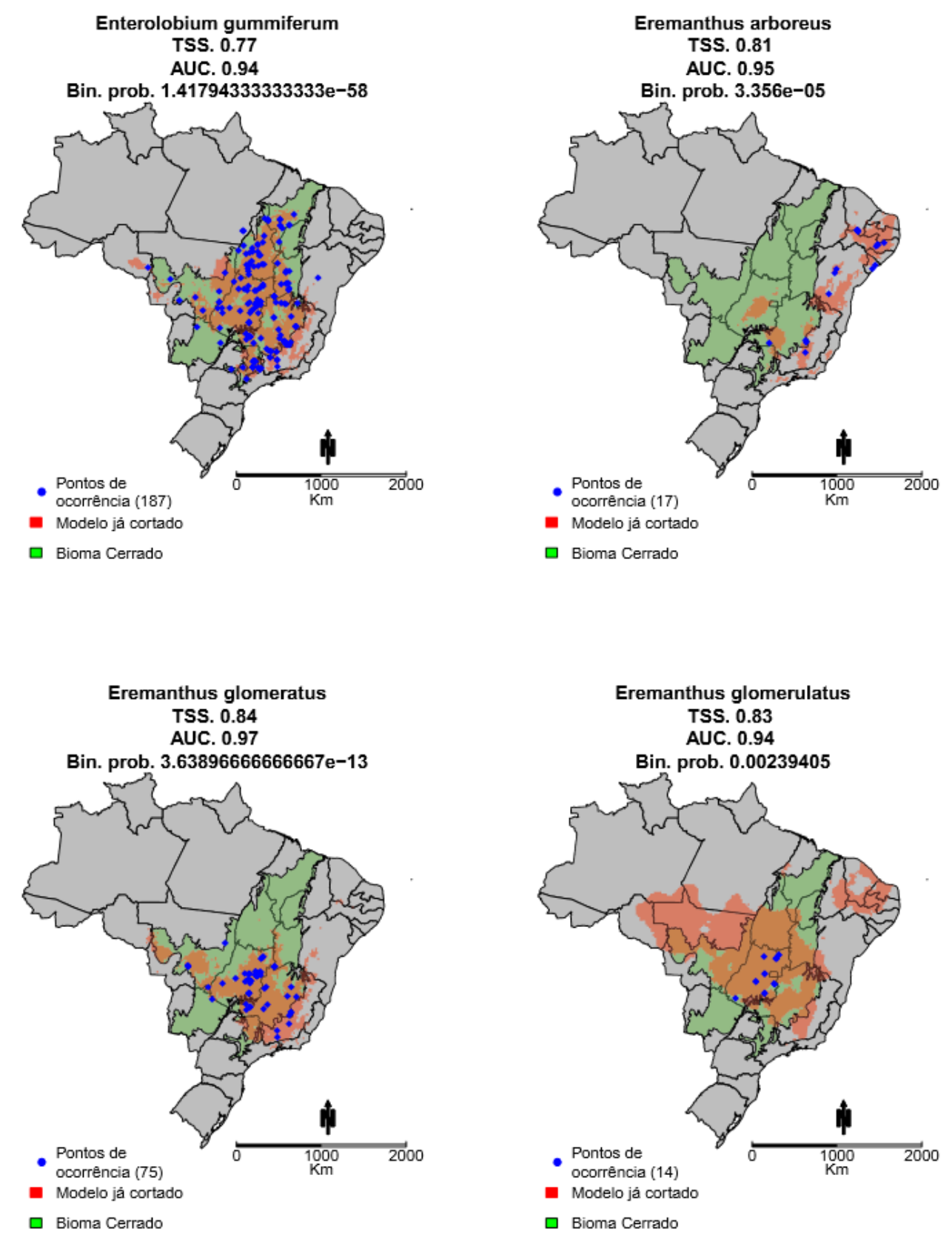



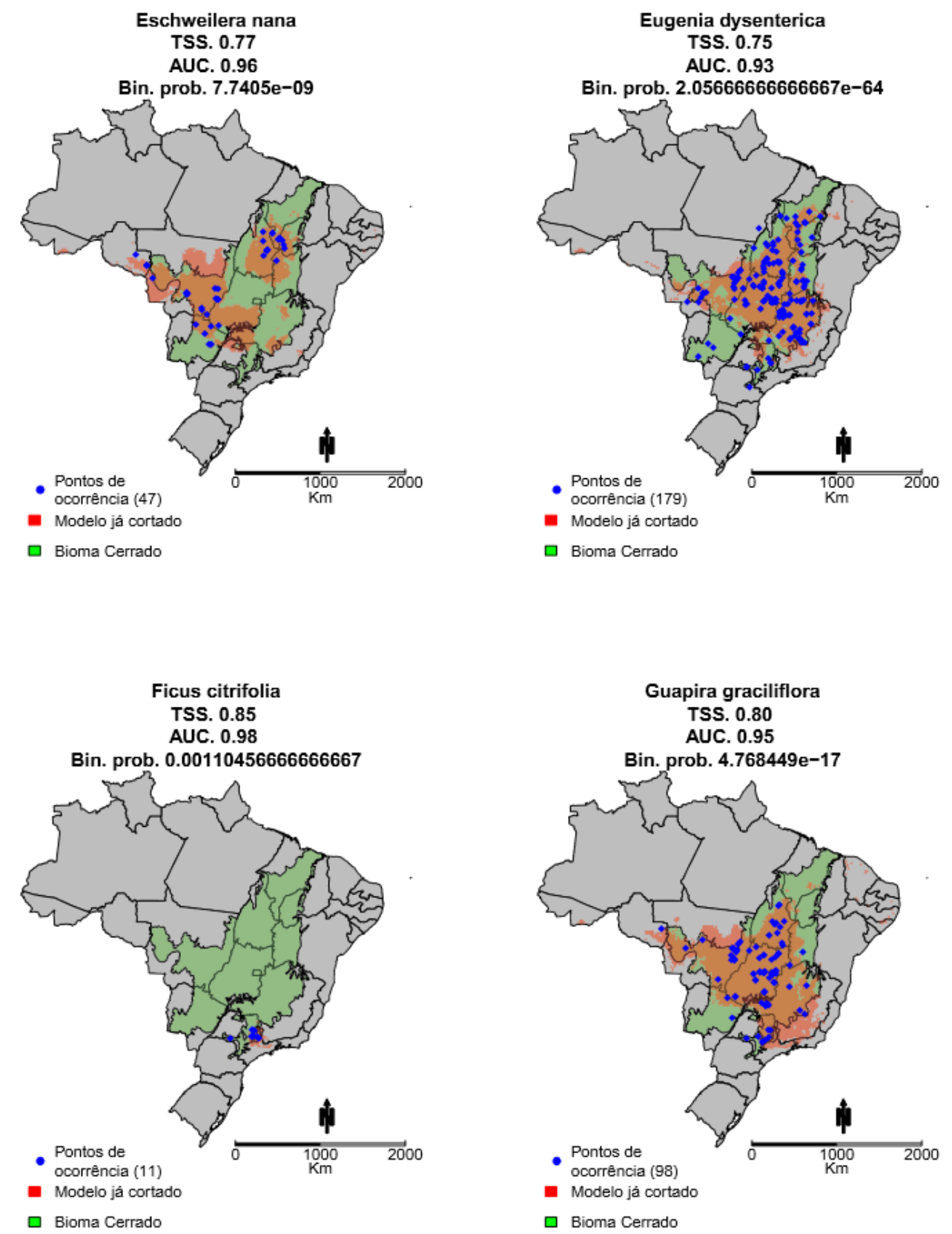

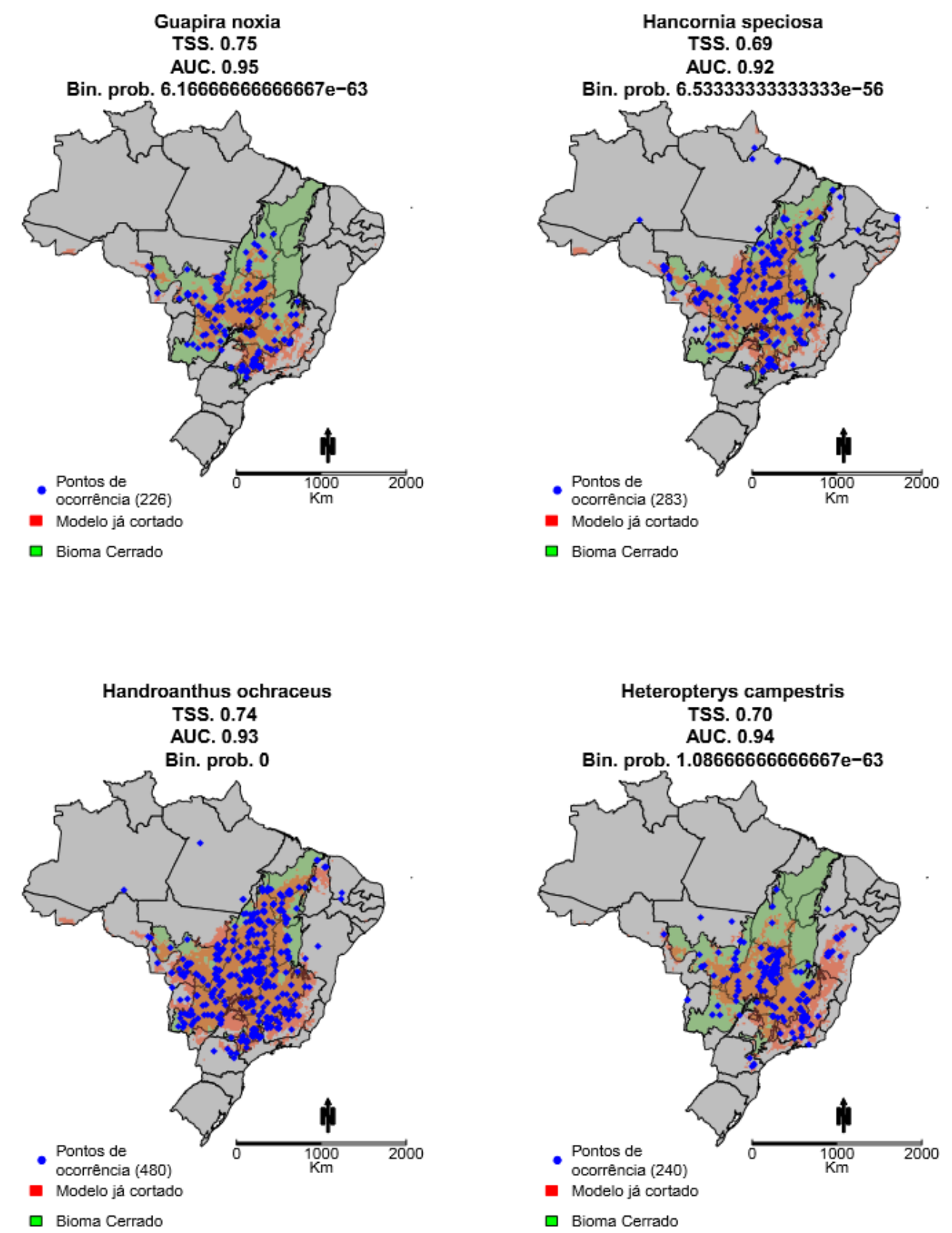

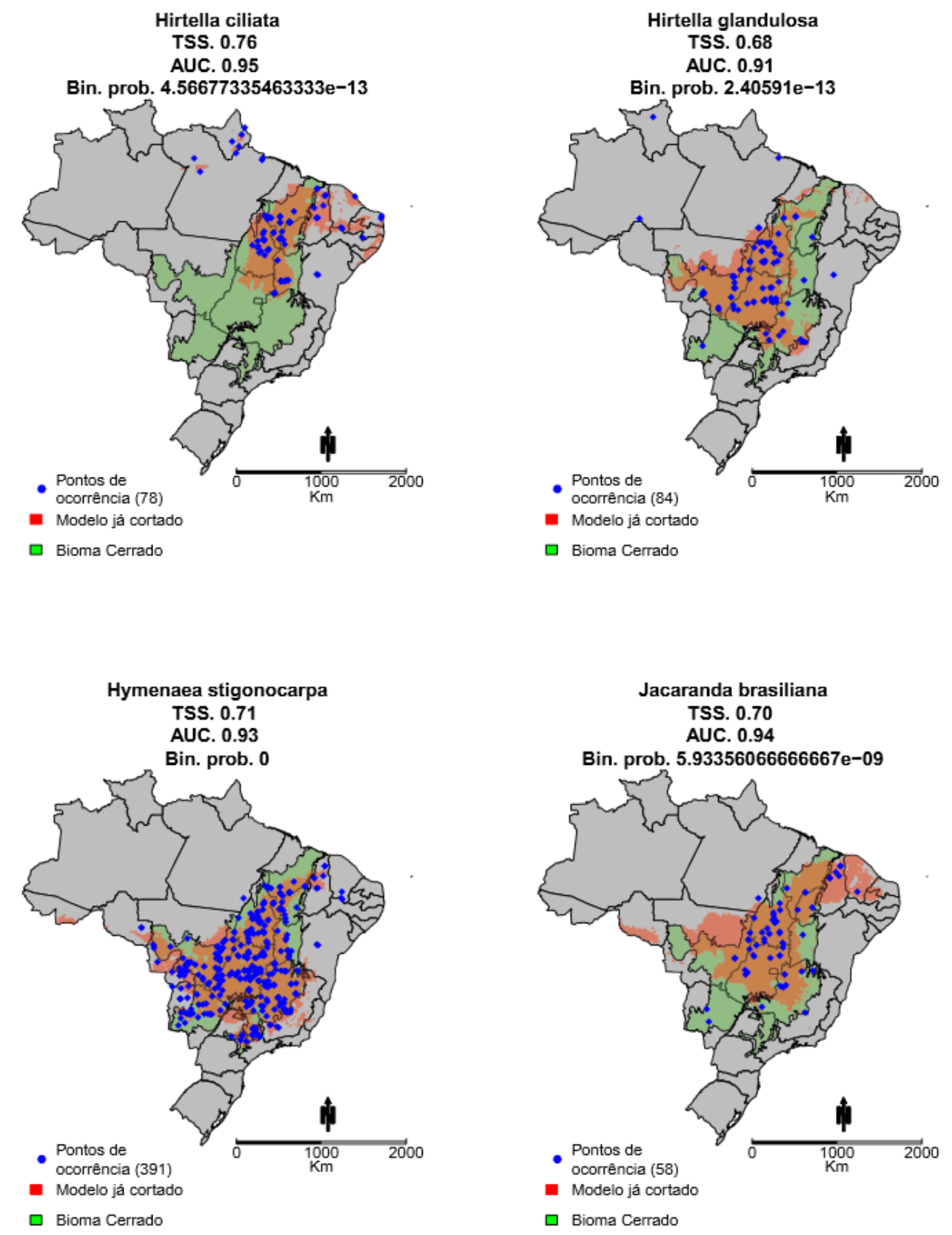

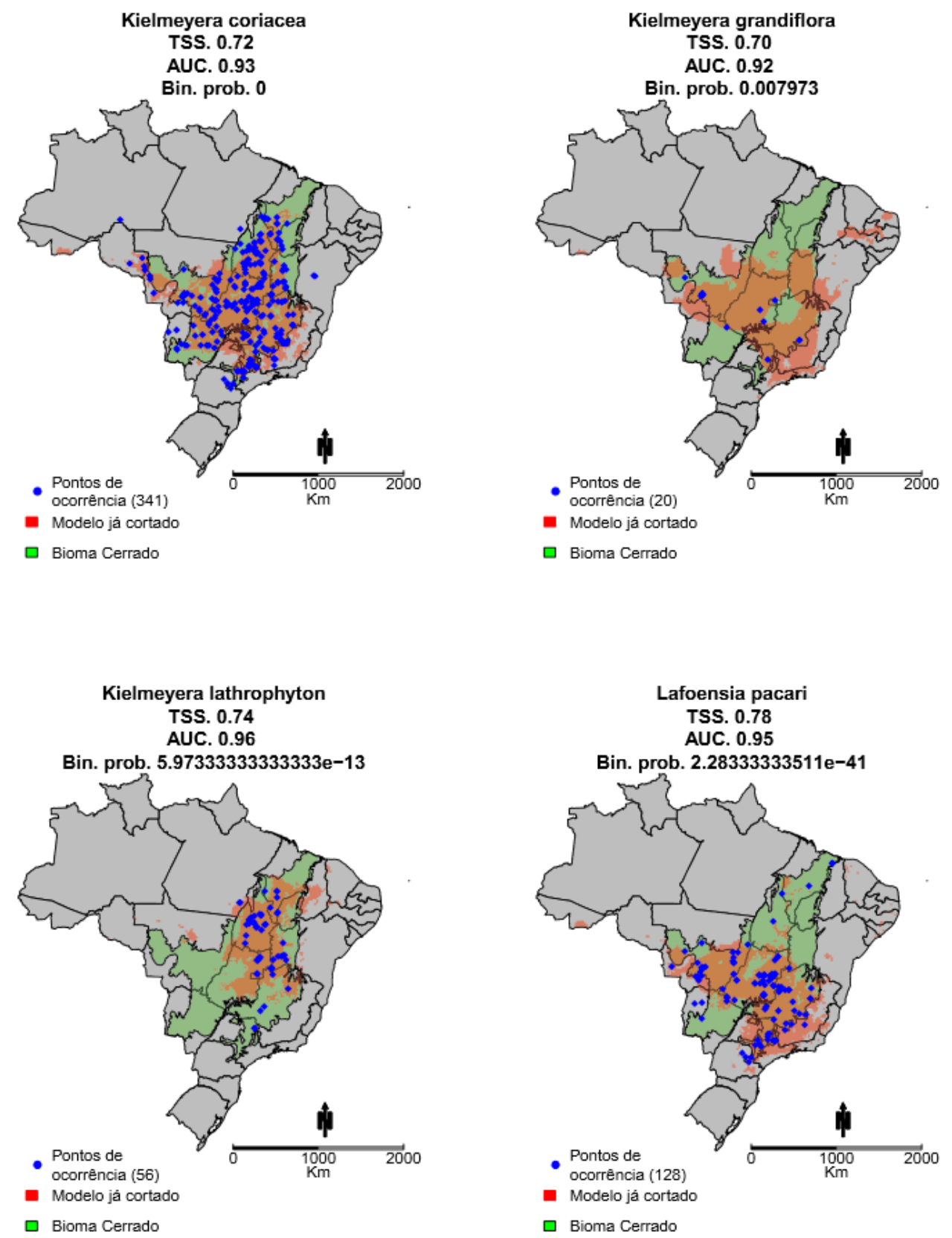



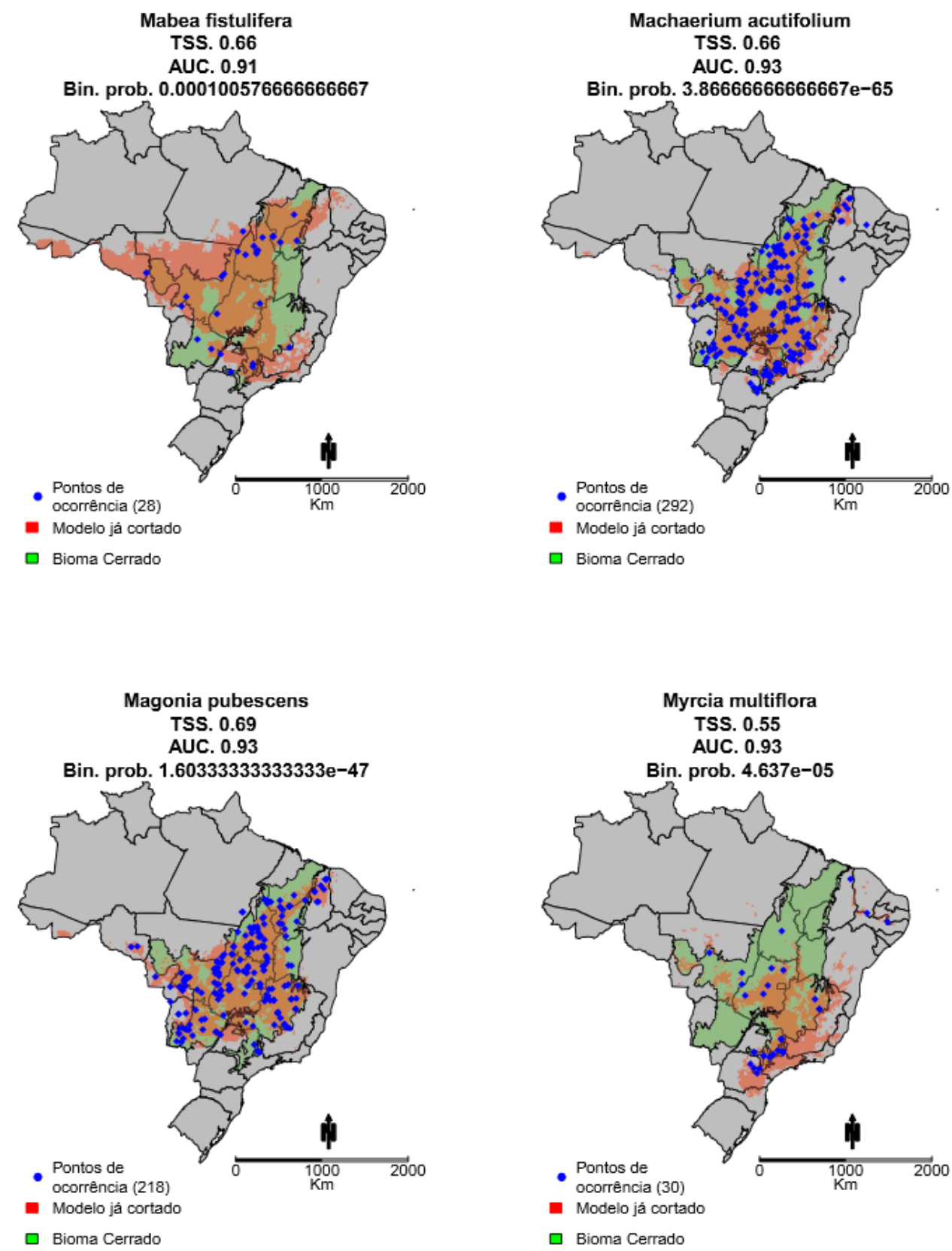

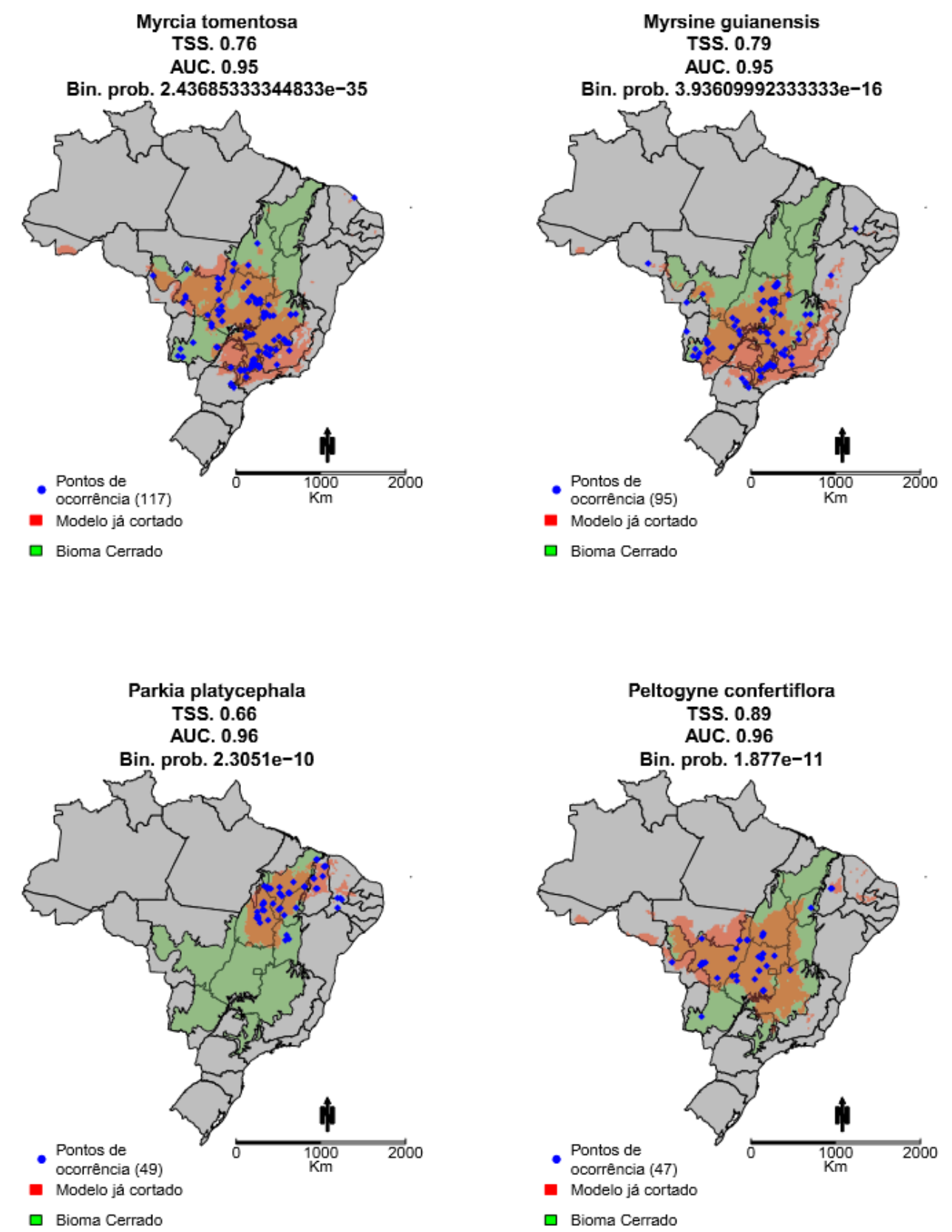

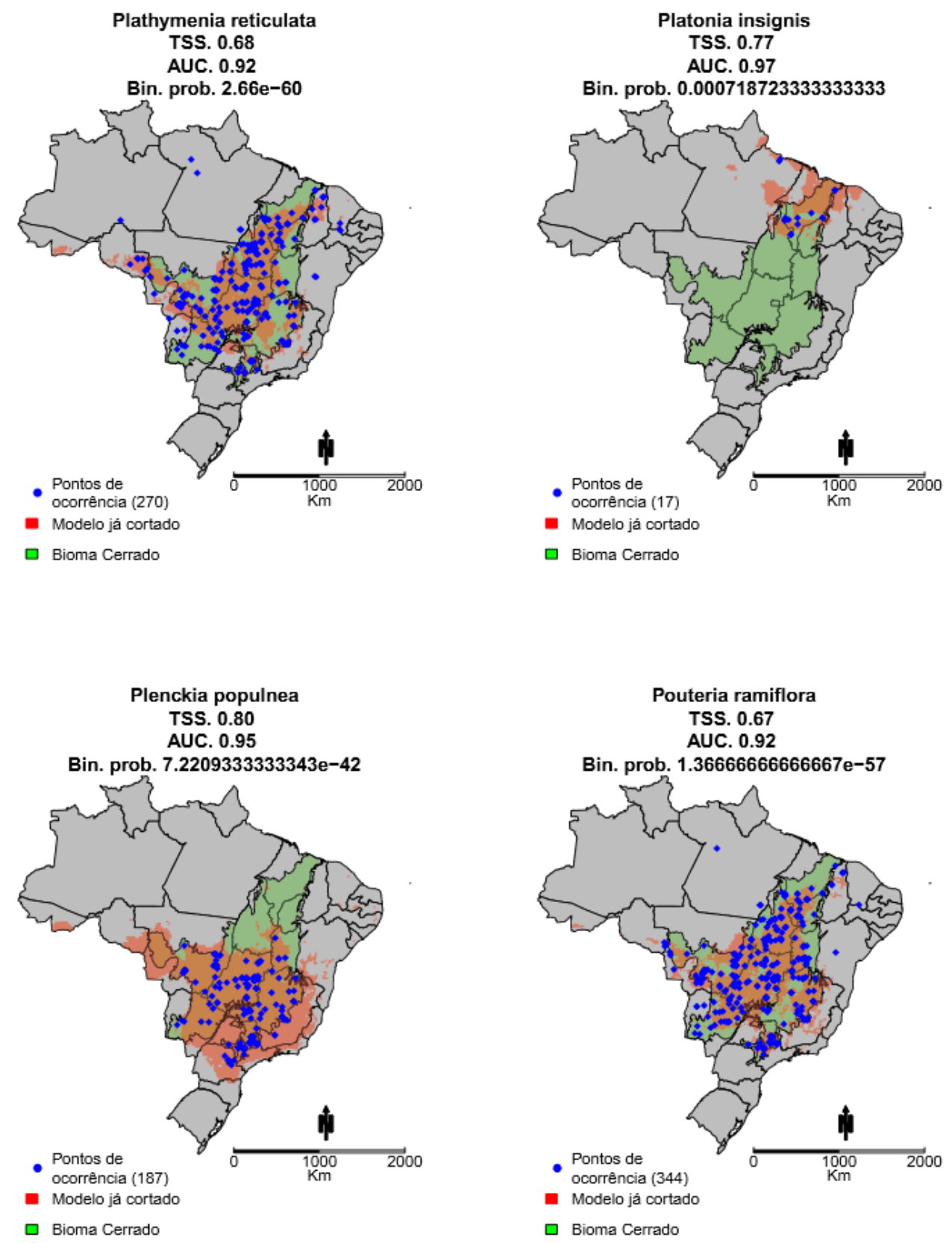

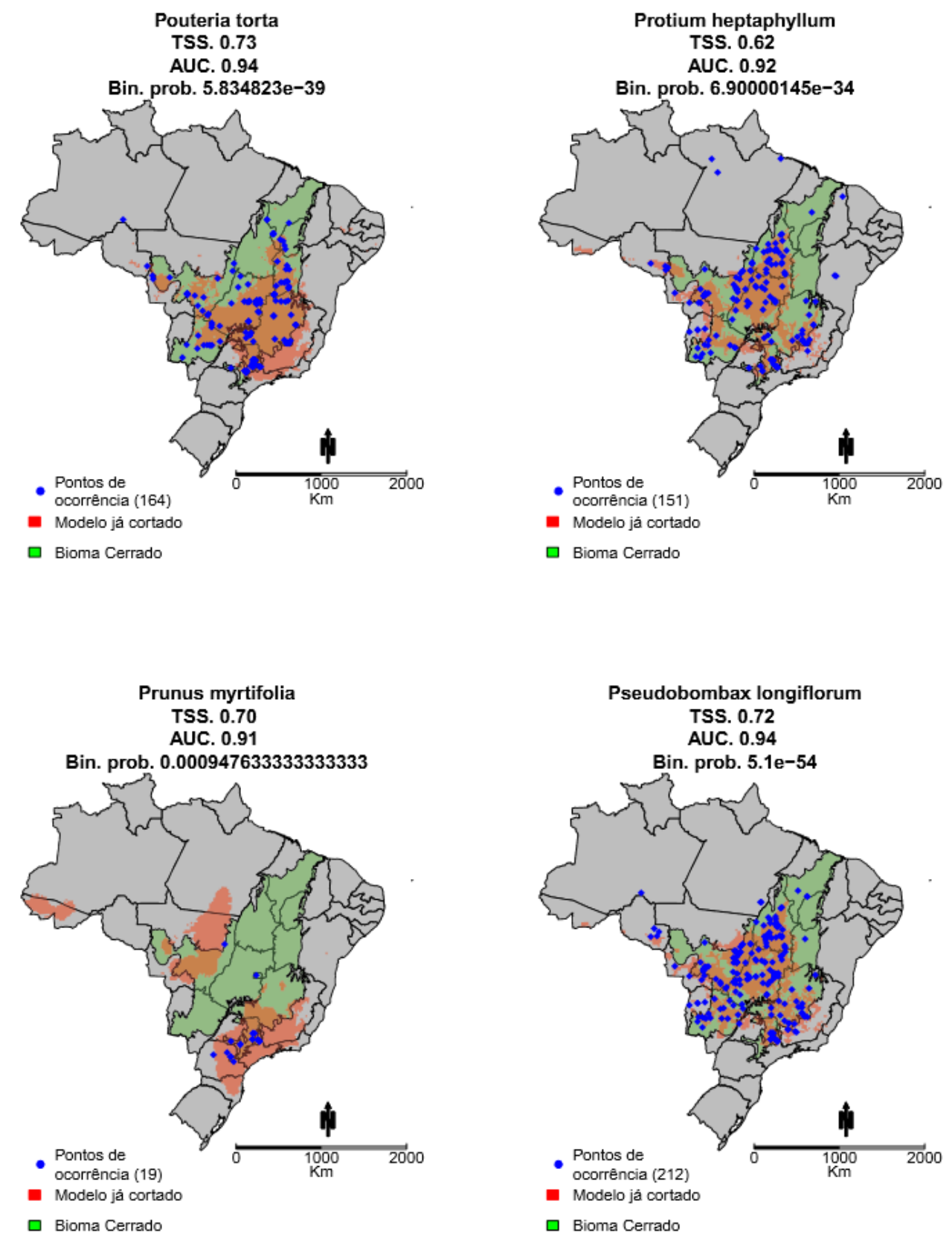
Pseudobombax tomentosum

TSS. 0.74

AUC. 0.94

Bin. prob. 8.46787616666667e-35



ㅁ Bioma Cerrado

Pterodon emarginatus

$$
\text { TSS. } 0.81
$$

AUC. 0.95

Bin. prob. 2.23266666666781e-40

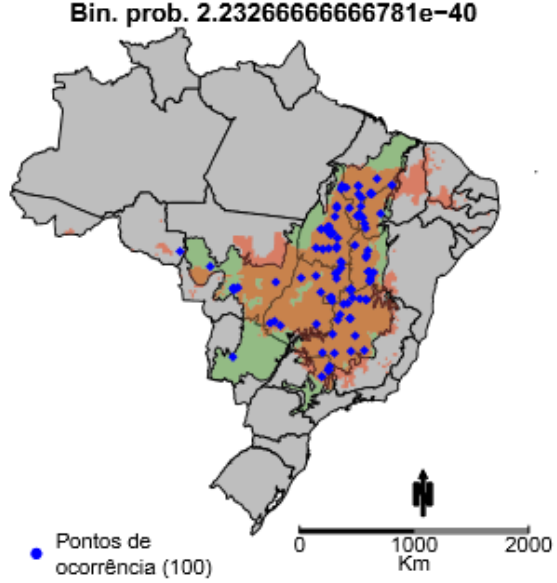

- ocorrencia (100)

- Modelo já cortado

Bioma Cerrado
Psidium myrtoides

TSS. 0.76

AUC. 0.94

Bin. prob. 1.11766666699567e-51

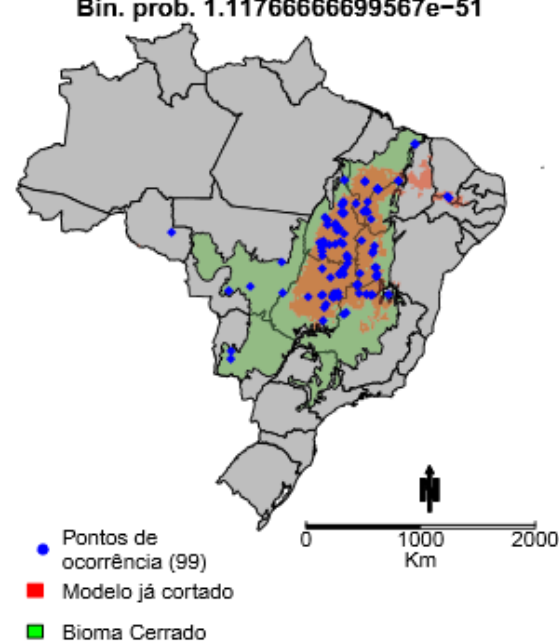

$\square$ Bioma Cerrado

Pterodon pubescens

TSS. 0.80

AUC. 0.94

Bin. prob. 4.50000002743333e-34

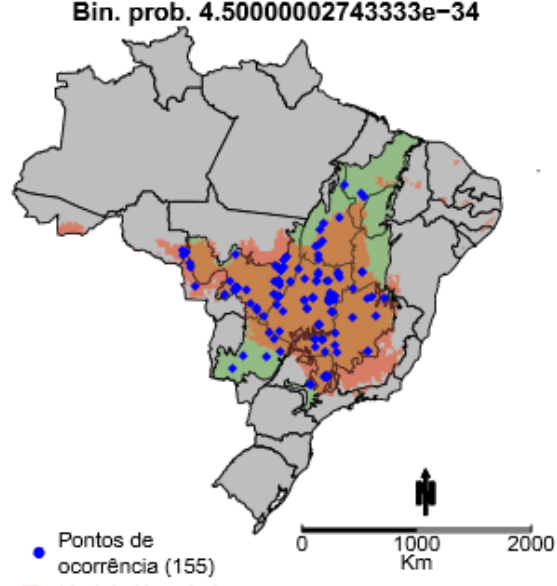

Modelo já cortado

$\square$ Bioma Cerrado 

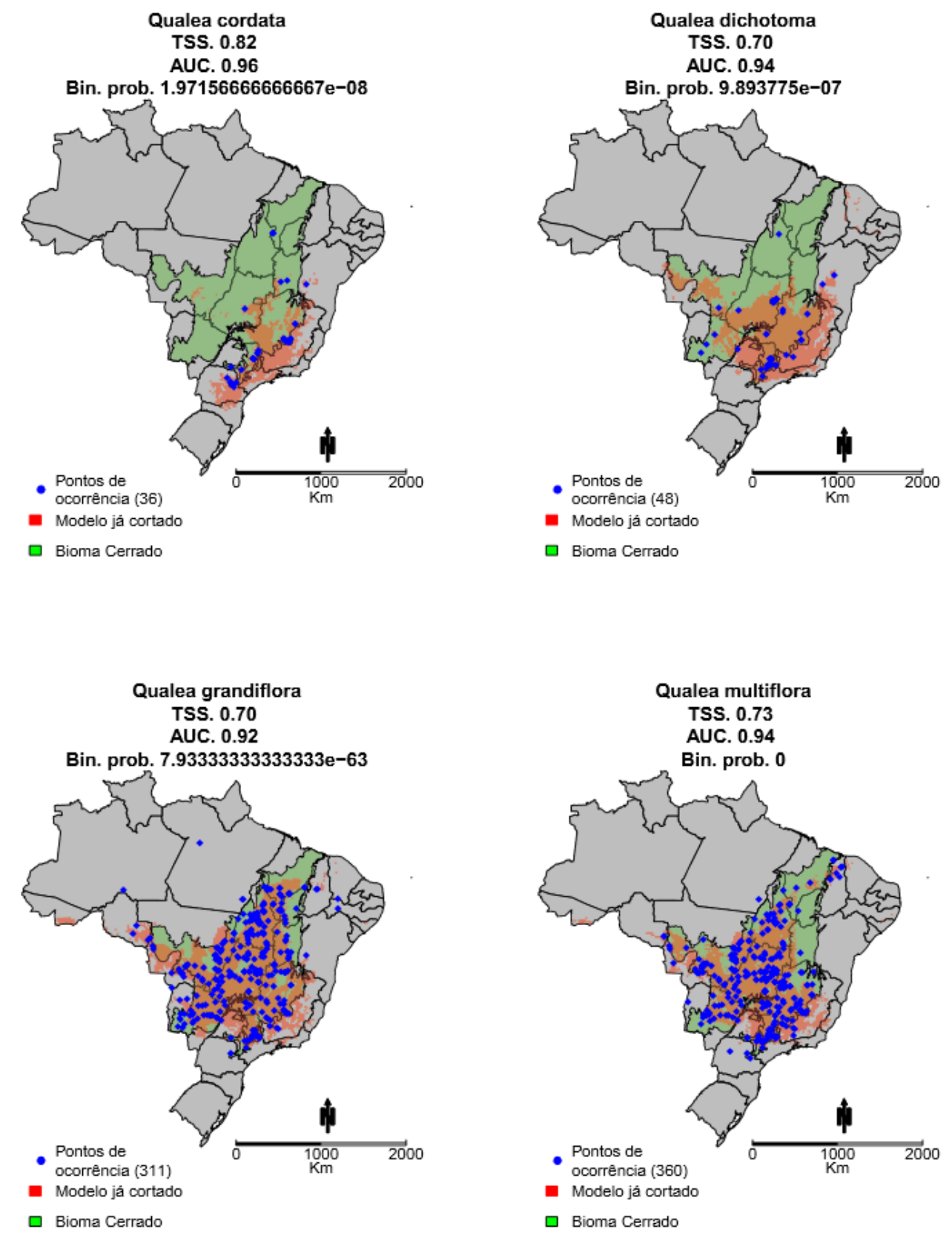

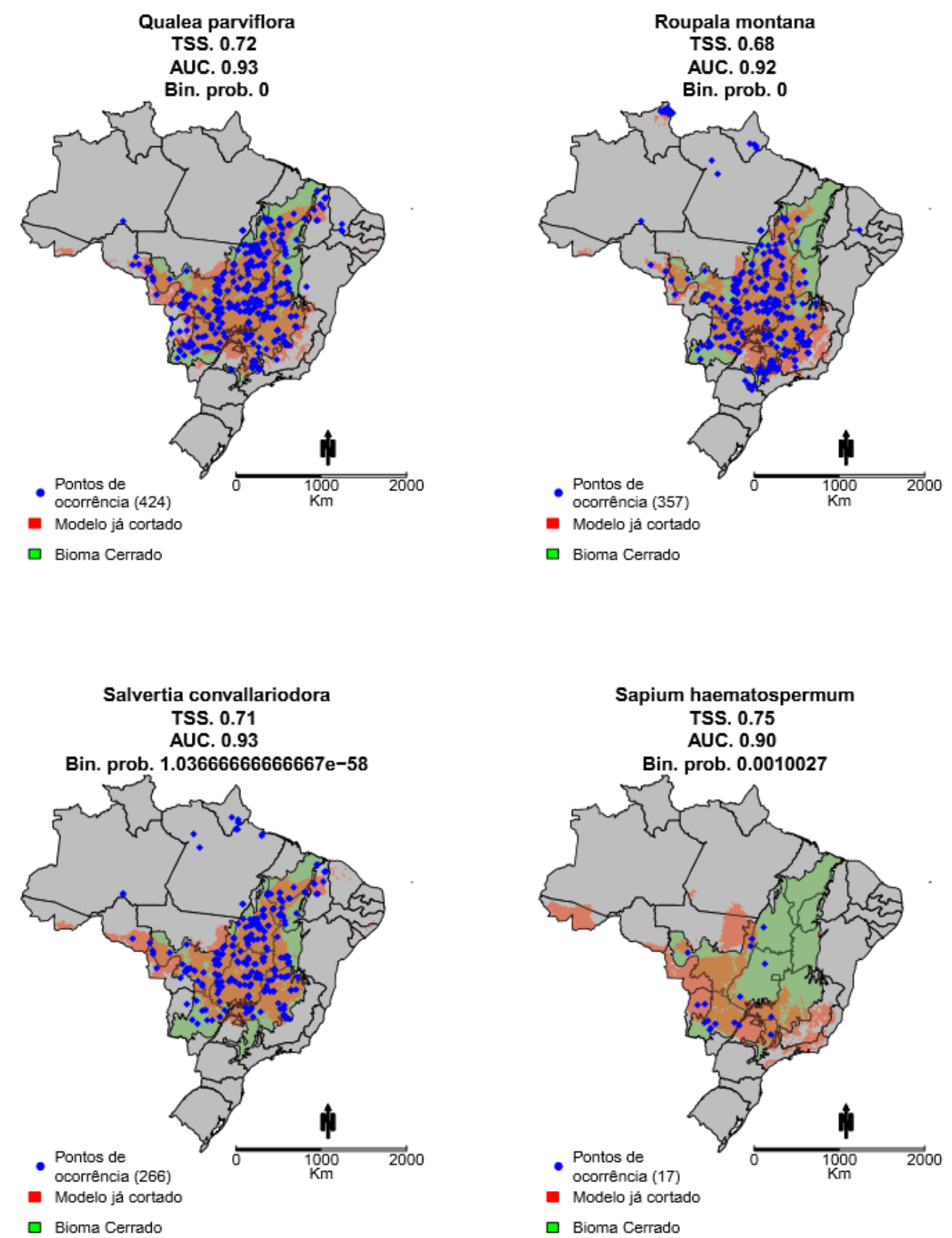
Schefflera macrocarpa

TSS. 0.86

AUC. 0.96

Bin. prob. 3.12104533333333e-55

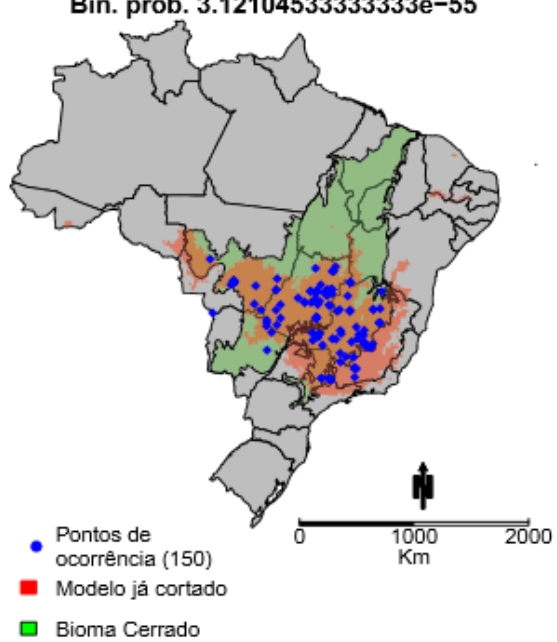

Strychnos pseudoquina

TSS. 0.72

AUC. 0.94

Bin. prob. 2.24666666804e-53



- ocorrencia (213)

- Modelo já cortado

ㅁ Bioma Cerrado

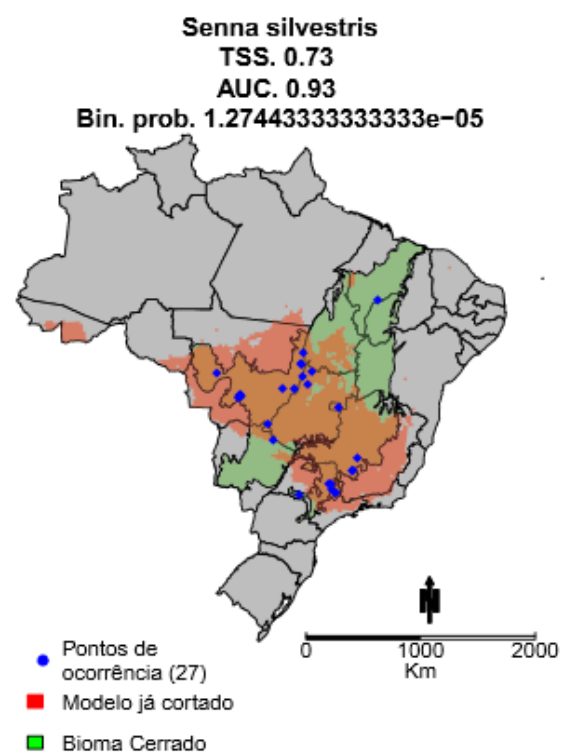

Styrax ferrugineus

TSS. 0.76

AUC. 0.95

Bin. prob. 9.01766666666667e-44

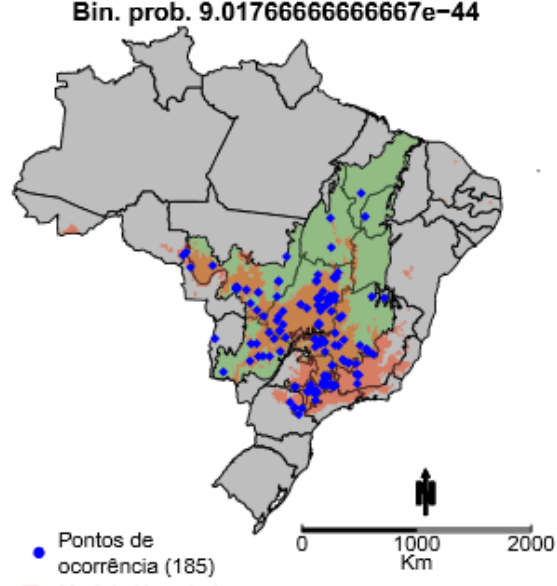

- Modelo já cortado

$\square$ Bioma Cerrado 
Symplocos rhamnifolia

TSS. 0.83

AUC. 0.96

Bin. prob. 0.002478666666666667

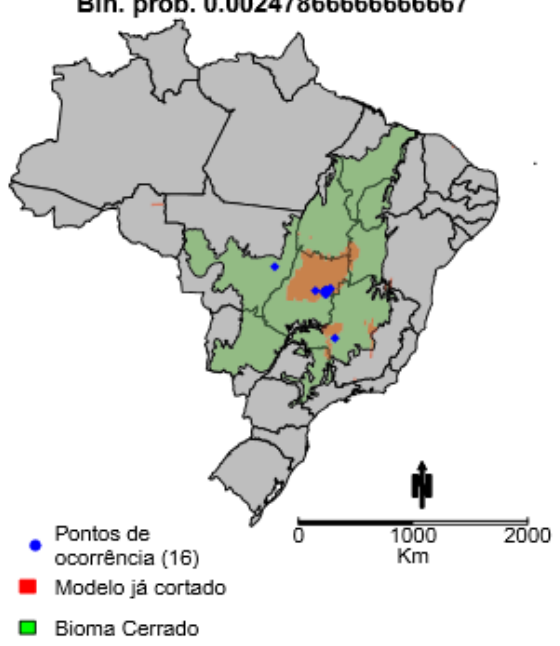

口 Bioma Cerrado

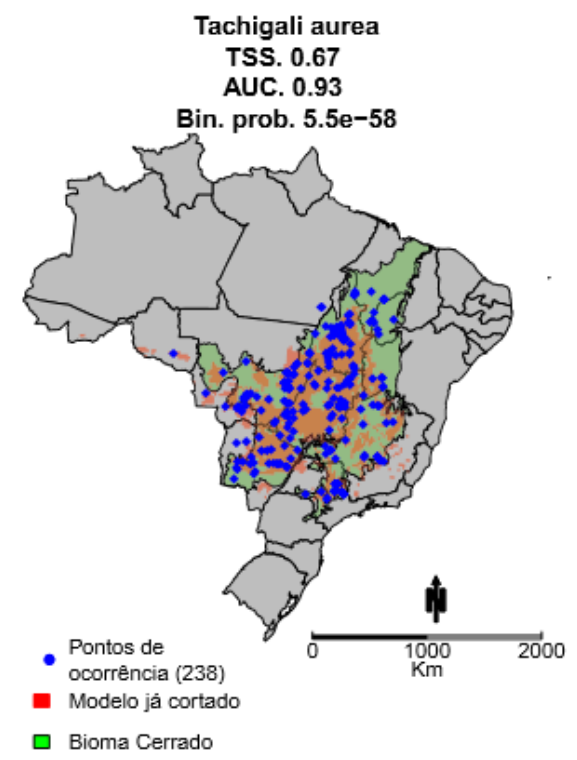



Tachigali subvelutina

$$
\text { TSS. } 0.70
$$

AUC. 0.93

Bin. prob. 1.62676666666667e-55

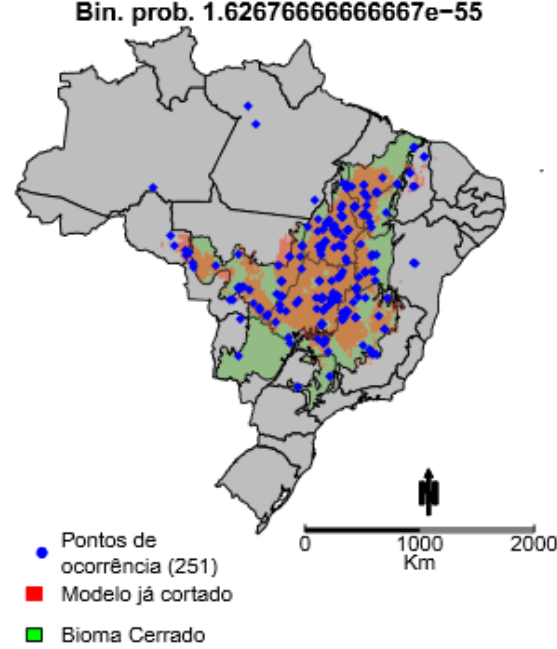



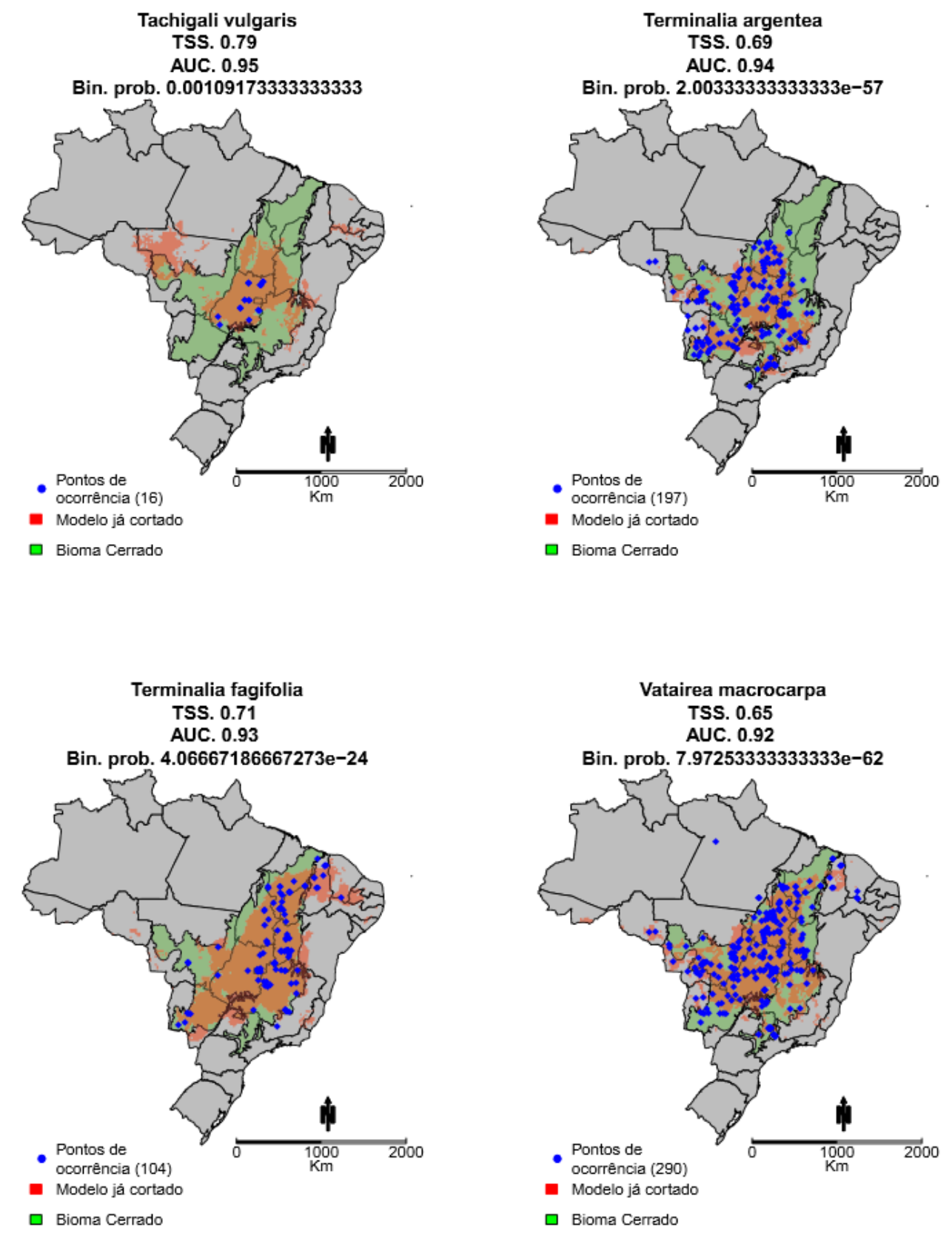

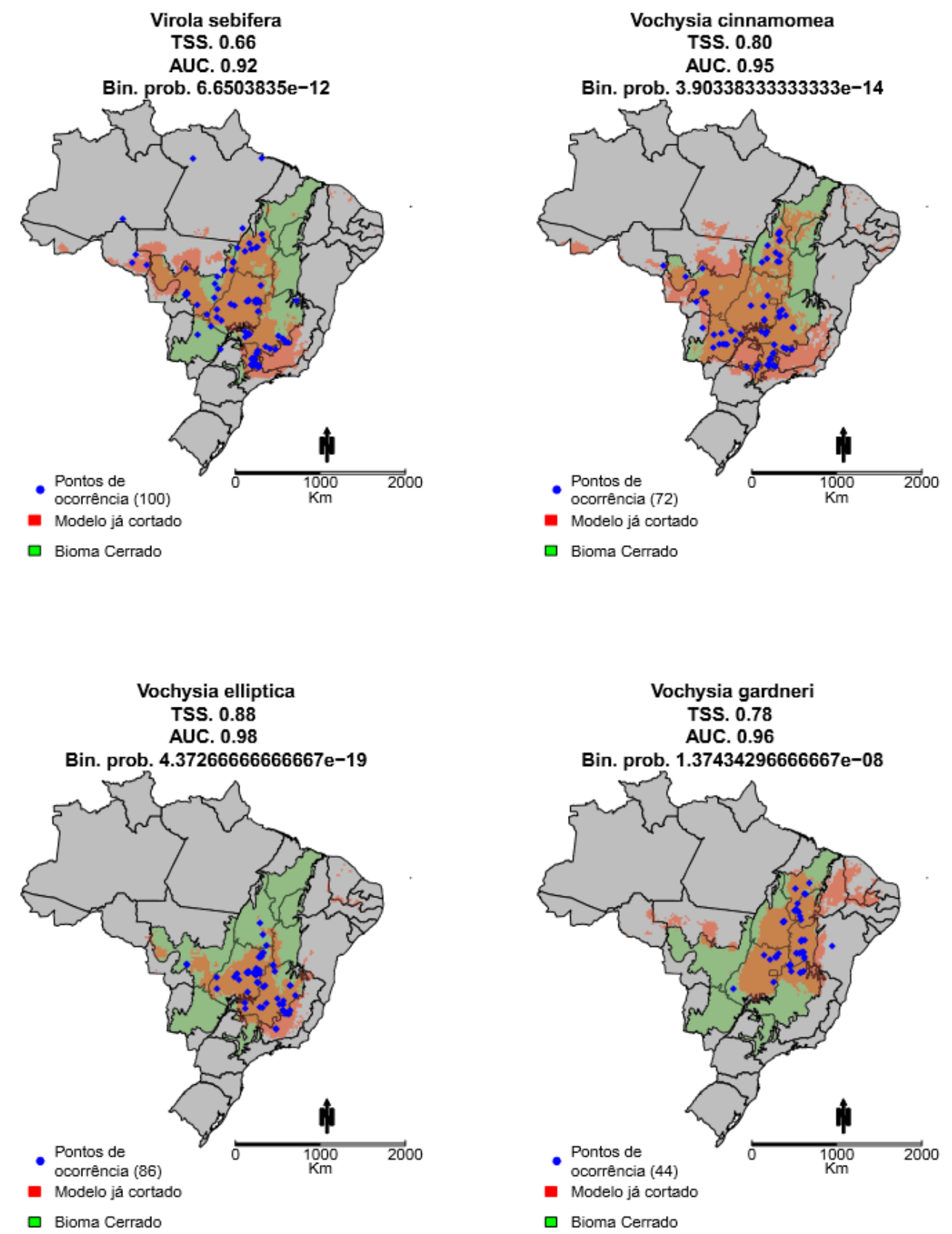

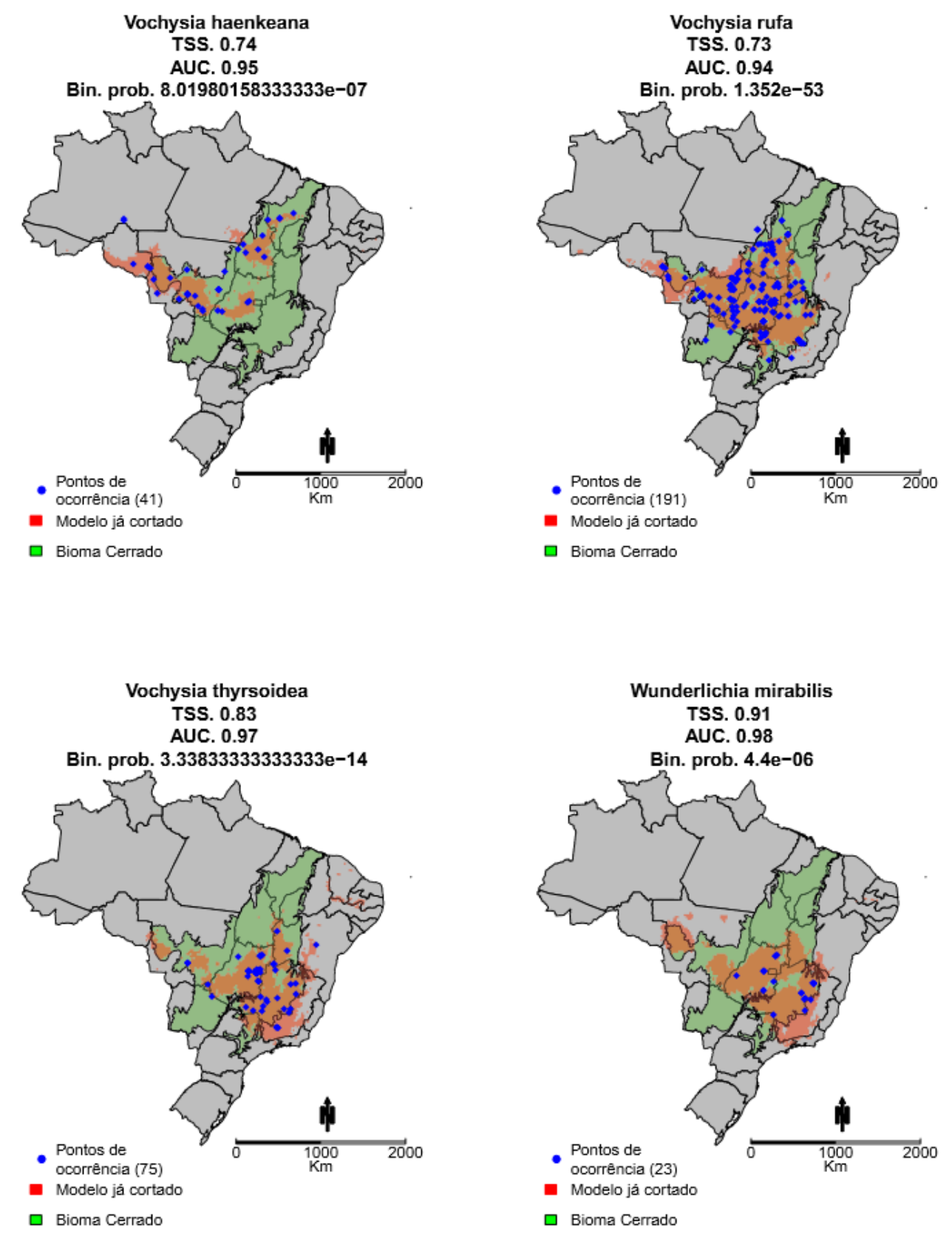
Xylopia aromatica

TSS. 0.68

AUC. 0.93

Bin. prob. 1.78333333333333e-59

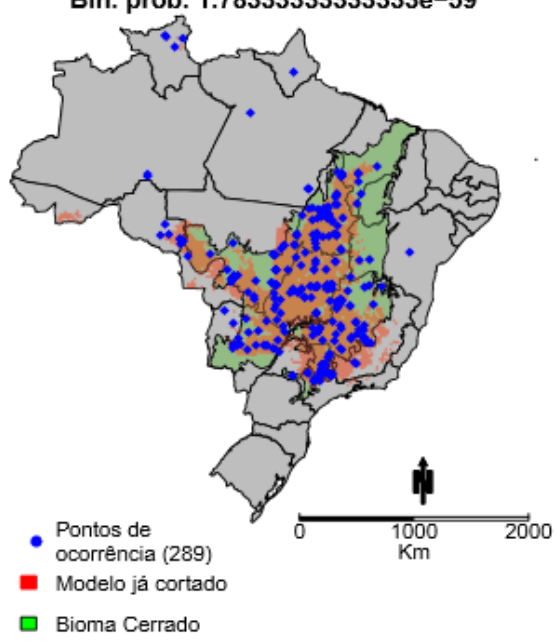

Zanthoxylum rhoifolium

TSS. 0.73

AUC. 0.93

Bin. prob. 1.070581e-12

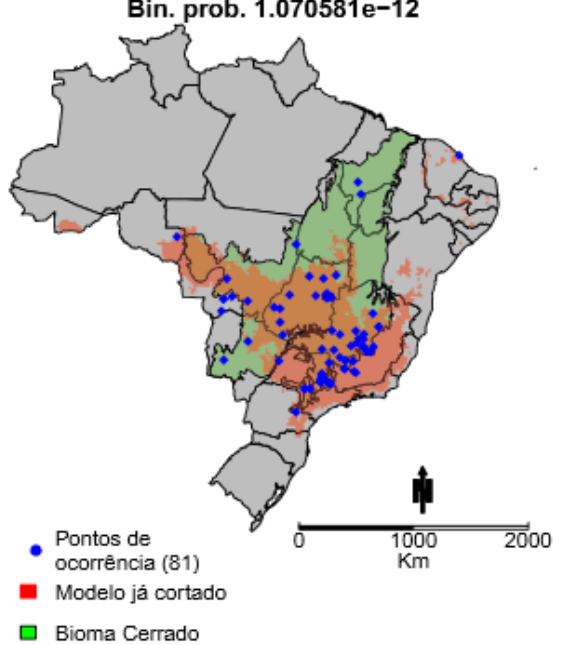

Zanthoxylum riedelianum

TSS. 0.79

AUC. 0.94

Bin. prob. $6.26 \mathrm{e}-15$

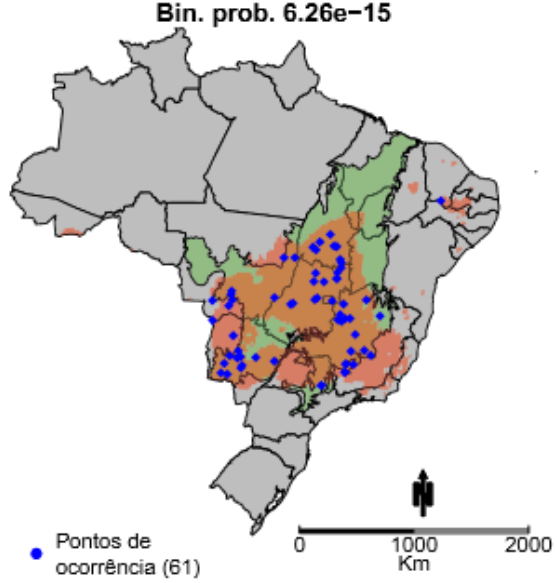

- ocorrencia (61)

2000

- Modelo já cortado

$\square$ Bioma Cerrado 